\title{
A New Radiocarbon Chronology for Ancient Iron Production in the Meroe Region of Sudan
}

\author{
Jane Humphris • Thomas Scheibner
}

Published online: 19 October 2017

(C) The Author(s) 2017. This article is an open access publication

\begin{abstract}
Recent archaeometallurgical investigations in Sudan have provided 97 radiocarbon dates which are used here to present a new chronology for ancient iron production associated with the Kingdom of Kush. Understandings of the formation, stratigraphy and dating of metallurgical waste deposits are used to demonstrate that iron production was practiced in the Meroe area for more than 1000 years, potentially starting as early as the 25th Dynasty period. Likely dates for the emergence and ending of iron smelting are considered in relation to political, economic and socio-cultural developments. The value and potential of this new chronology are explored, for example, in terms of insights into scale of production over time and resulting indications of organisation and management of this ancient technology.
\end{abstract}

Résumé Des recherches archéométallurgiques issus récemment du Soudan ont fourni 97 datations par le radiocarbone. Nous utilisons ces données-ci pour présenter une nouvelle chronologie de la production de fer ancienne associée au Royaume de Koush. En analysant la formation, la stratigraphie et la datation des dépôts de déchets métallurgiques, nous démontrons que la production de fer a été pratiquée dans la région de Meroë pendant plus de 1000 ans, commençant potentiellement

J. Humphris $(\bowtie)$

UCL Qatar, Doha, Qatar

e-mail: j.humphris@ucl.ac.uk

T. Scheibner

Archaeological Research and Service, Berlin, Germany dès la période de la 25ème dynastie. Nous considérons les dates probables de l'émergence et la cessation la production de fer en relation avec des développements politiques, économiques et socioculturels. Nous explorons la signification de cette nouvelle chronologie en fonction des idées qu'elle peut offrir en ce qui concerne l'échelle de production au fil du temps et l'organisation et la gestion conséquente de cette technologie ancienne.

Keywords Meroe $\cdot$ Kush $\cdot$ Iron production . Chronology $\cdot$ Radiocarbon $\cdot$ Slag heap

\section{Introduction}

The extensive remains of ancient iron production activities found at Meroe, a Royal capital of the Kingdom of Kush, were first mentioned in an archaeological publication by Garstang et al. (1911, p. 21), but were immortalised by Sayce: "Meroe, in fact, must have been the Birmingham of ancient Africa; the smoke of its iron smelting furnaces must have been continually going up to heaven, and the whole of northern Africa might have been supplied by it with implements of iron" (Sayce 1912, p. 55; see also Wainwright 1945, p. 22). Meroe's iron technology gained further notoriety following Wainwright's 1945 consideration of Iron in the Napatan and Meroitic Ages. Here, Wainwright suggested that Ionian and Carian mercenaries brought iron objects to Napata by the sixth century BC (see also Arkell 1961, p. 130 ), and that the production of iron had begun "on a 
gigantic scale" at Meroe by the mid-first century BC (see also Shinnie 1967, p. 162).

From the 1960s, Meroe's metallurgical history was embedded within considerations of the origins of iron production in Africa (Shinnie 1967, pp. 161, 165-168), based at the time on the supposition that such technologically complex knowledge as iron production must have been transported into the continent from the north, possibly along the Nile Valley. That the earliest iron objects recovered in Egypt are made from highly valued meteoric iron (Comelli et al. 2016; Ogden 2000; Rehren et al. 2013), and that iron production does not appear in Egypt at earlier dates than it appears further to the south or west (Craddock 1995, p. 261), currently negates a theory of Nile Valley diffusion. Trigger attempted the first comprehensive consideration of the role of Meroe in the spread of iron metallurgy in Africa, noting that despite a lack of evidence, "Meroe seems well on its way to being regarded as the hearth of sub-Saharan African civilization and a principal transmitter to the rest of the continent of traits coming from the north" (1969, p. 25). His assessment of the available evidence led him to conclude that iron production may have begun in Sudan as far back as the fourth century BC (1969, p. 49). However, as Rehren noted (2001, p. 102), information and ideas relating to Meroe's iron production industries were based on little evidence until archaeometallurgical research was conducted at the site in the late 1960s and early 1970s.

Based on the seminal archaeometallurgical work of Shinnie and Tylecote at Meroe (Shinnie 1985; Shinnie and Kense 1982; Tylecote 1970, 1982), a much-cited radiocarbon date of the late sixth century $\mathrm{BC}$ was provided for what was believed at the time to be the earliest iron production at the site (Shinnie and Kense 1982, pp. 19-24). However, Shinnie and Kense are careful to note that the sixth-century BC date should be "used with caution." This single radiocarbon date was obtained from a level within which slag was found associated with a wall, while the charcoal sample itself was taken from the mud mortar of the wall (Shinnie and Kense 1982, p. 24; although see Shinnie and Anderson 2004, pp. 73-74, where the authors suggest a sixth-century BC date for the earliest iron smelting at Meroe is not unreasonable). Additionally, dates of the fourth to first century BC produced from a number of charcoal samples taken from "furnace bottoms" were also later described as problematic. Thus the original absolute dates for the earliest phases of iron production at Meroe seem questionable.
The radiocarbon dates obtained from iron production workshops excavated on the North Mound of the site seem until now to be the only reliable absolute dating evidence for smelting at Meroe, from between AD 300500 (Shinnie and Kense 1982, p. 24). However, even these dates appear to come from areas associated with the furnaces, rather than from the furnaces themselves (Shinnie and Anderson 2004, pp. 74-79). Since this initial archaeometallurgical research more than 40 years ago, no further chronological information has been provided for the iron industries of the Meroe area.

From 2012, new archaeological investigations have been undertaken to reveal and contextualise the technological development of iron production in the Meroe region, including the generation of a chronological framework within which to situate the new archaeological results. To date, archaeometallurgical investigations have been carried out at five large slag mounds at Meroe, Meroe iron slag (MIS) 2-4, 6 and 7, and four slag mounds at the Meroitic site of Hamadab, c. $3 \mathrm{~km}$ to the south of Meroe (HMD 100, 200, 300 and 800; Fig. 1). Another, presumably Meroitic iron production location is located at the site of Muweis, c. $50 \mathrm{~km}$ to the south of Meroe (Baud 2008, p. 60). This site is under excavation by the French Louvre team and no information is currently available concerning the iron production remains. El-Hasa, a Meroitic site situated between Meroe and Muweis, is often cited as a further iron production location. However, it would seem that any iron production here took place on a small scale, or that the iron production remains previously noted have since been covered, perhaps by sand encroachment.

\section{Methodology and Critique}

\section{Field Techniques}

Excavation trenches were positioned within the slag mounds based on the results of field and geophysical surveys with the aim of obtaining as much information as possible from the metallurgical deposits. These deposits contained various types of iron slag, technical ceramics, ore fragments and charcoal, as well as nonmetallurgical debris. Representative samples of material required for laboratory analysis were collected from the slag mound excavations in two ways. The first sampling strategy involved the content of the trenches which, due to the complex nature of the metallurgical waste 


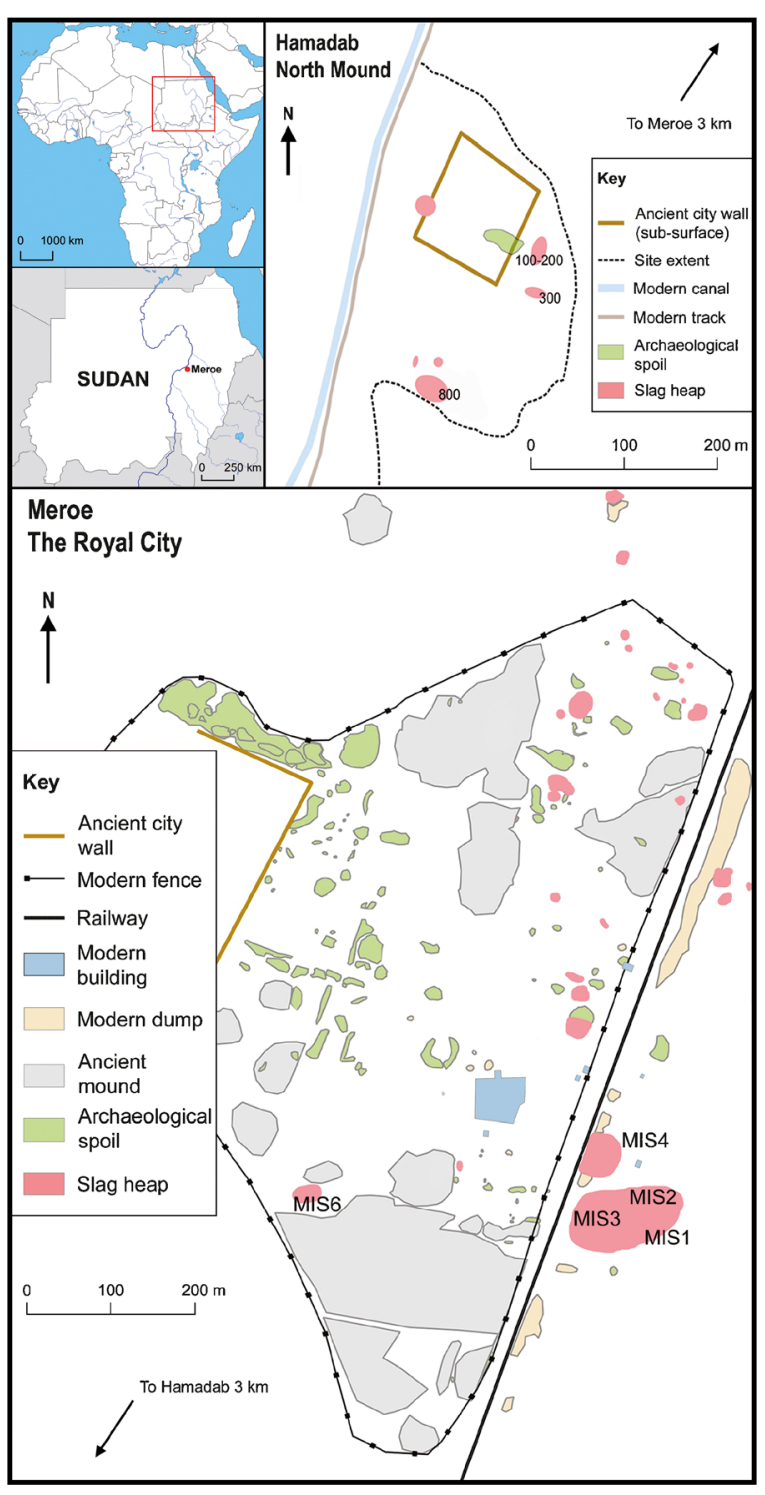

Fig. 1 Map of Meroe and Hamadab showing the locations of the sites and the slag mounds mentioned in the text (all images in full colour online)

deposition and resulting stratigraphy, was removed in spits of defined depth. Material recovered from these spits was processed and sampled to understand the type and quantity of metallurgical and non-metallurgical debris present in each mound (Humphris and Carey 2016). The second strategy involved collecting samples from contexts defined and documented within the trench sections. Charcoal samples sent for radiocarbon dating were generally selected from lower, middle and upper contexts of each trench section to provide a chronology for the evolution of the slag mounds and thus, following interpretation of the dates in relation to the stratigraphy of the slag mounds (see below), for iron production at Meroe and Hamadab (Figs. 2 and 3). Where possible, charcoal samples found embedded within slag fragments were sent for dating to ensure the resulting radiocarbon dates can be directly related to iron smelting events. However, all charcoal samples sent for dating were interpreted as being used within the iron production process, hence their deposition within mounds dominated by metallurgical waste. The exact stratigraphic positioning of all dates is not provided in this publication (this will be included in future, more detailed archaeological publications).

Despite the systematic approach to the collection of charcoal samples for radiocarbon dating, a number of factors could have influenced the original formation of slag mounds and thus the validity of the sample collection strategies. The stratigraphic sequence evident in a trench section does not necessarily reflect the absolute chronological order of metallurgical waste production or the formation of the mound. In the course of mound formation, older material may have been deposited over younger material, for example if waste from earlier metallurgical production was moved. Furthermore, the original handling of iron production waste is almost impossible to reconstruct: iron production spaces and workshops could have been regularly cleaned and the waste may have been carried to the slag mound immediately, or this waste could have remained in the workshop's vicinity first until a certain amount of waste was produced, before deposition on the slag mound; an earlier abandoned workshop area could have been cleaned of its final waste to be re-used after a period of time. This asynchronous material would then be embedded in the relative sequence of the slag mound stratigraphy, which we otherwise assume to represent a consistent chronology.

The slag mounds furthermore contain a complex horizontal stratigraphy due to their formation process, which is not possible to understand before excavation. Hence the positioning of trenches could not be adjusted in advance in order to ensure the most meaningful sampling opportunities. In addition, although stratigraphy per trench is defined, stratigraphic relationships between distant trenches even positioned within the same mound usually remained elusive. Consequently, the stratigraphic evolution of the slag mounds and the positions of the trenches, and therefore the resulting availability of samples within the lower, middle and upper contexts, have affected the significance of the 


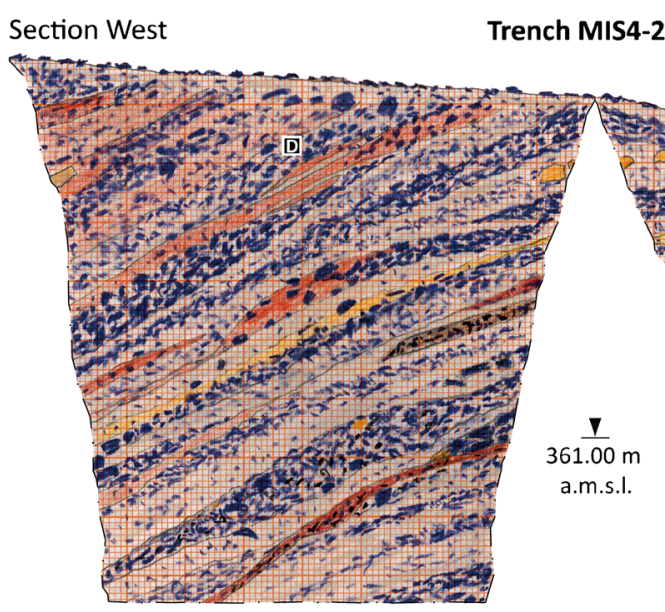

Samples

A Context 4054 - AA102869: 2,292 \pm 39 BP

B Context 4052 - AA102870: 2,590 442 BP

C Context 4045 - AA102871: 2,296 \pm 47 BP

D Context 4029 - AA102872: 2,327 \pm 33 BP
Section North

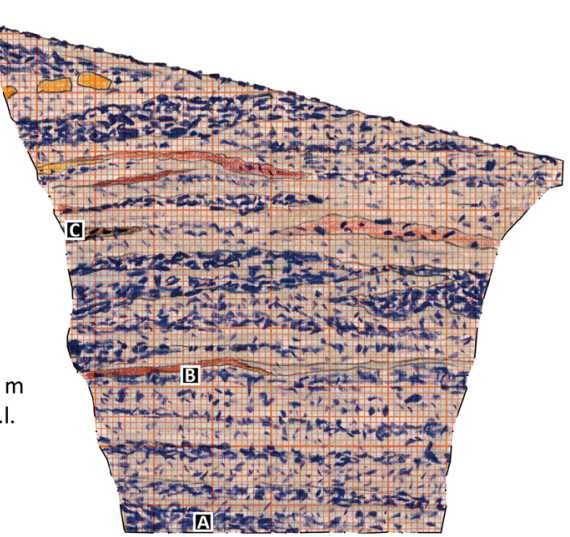

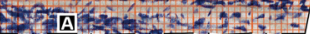

Fig. 2 Section drawing of the west and north sections of trench MIS4-2-13 showing the typical location of charcoal samples selected for dating

dating sequence and the resulting chronology produced here. The oldest and/or latest metallurgical contexts within a mound may not be revealed and/or sampled so far, and not every slag mound or sub-surface metallurgical deposit has yet been excavated, meaning that the oldest and/or latest metallurgy in the region may also not as yet have been sampled.

Therefore, although the field methodology for sample collection was carefully developed and implemented, excavation and sample collection bias, as well as the

$\begin{array}{lll}\text { Section West } \quad \text { Trench MIS4-3-13 Section North } & \text { S }\end{array}$
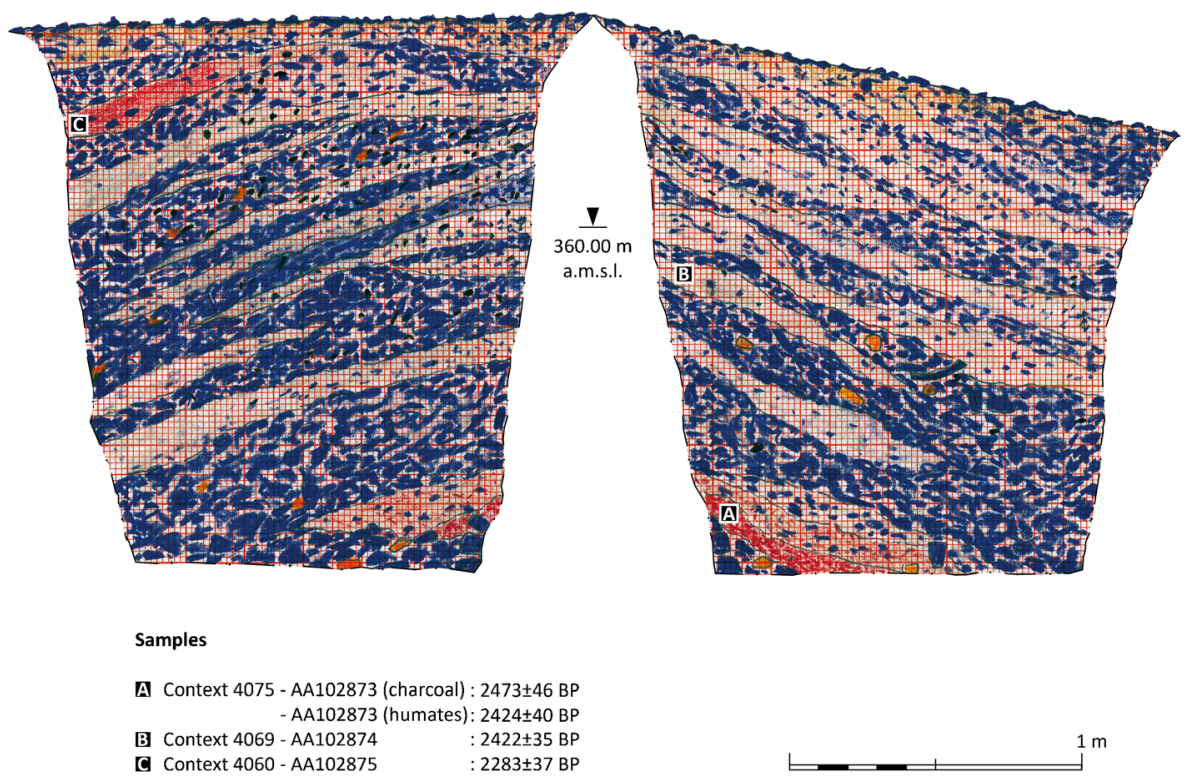

Fig. 3 Section drawing of the west and north sections of trench MIS4-3-13 showing the location of the charcoal samples selected for dating 
potential for haphazard slag mound formation, may have a role to play in some of the more complicated dating sequences revealed within and between trenches. It could be said that this does not affect the production of a chronology for iron production in the Meroe region based on radiocarbon dates obtained from the charcoal samples. However, we would argue that to produce a meaningful chronology that can be interpreted in relation to the evolution of the sites and of Kush, the radiocarbon dates must be considered in relation to slag mound formation (see below).

\section{Laboratory and Data Processing Techniques}

It is reasonable to assume that charcoal was produced relatively soon before the iron production process for which it was required (viz. that carbon exchange between the living tree and the environment ceased close to the iron smelting or smithing event, resulting in an ideal material for radiocarbon dating of iron production events). However, there is a possibility that the charcoal samples collected could have derived from old wood. Old wood refers to charcoal produced from the inner cores, or heartwood, of long-lived trees. Such charcoal would provide an older date based on the early life of the tree, rather than on the time at which the tree died and the charcoal was produced. Another potential for old wood would be the use of longdead wood for the production of charcoal that was then used for iron production. Certain African Acacia species, notably Acacia type nilotica which dominates the charcoal assemblages discussed here, are resistant to water and termites so in theory could lie dead for years before being used to produce charcoal (Wickens 1995, p. 64). To mitigate to a certain degree the possibility of producing a dating sequence affected by old wood, at least in terms of the sample being heartwood, each charcoal sample selected for dating was examined for possible indications of this phenomenon and discarded as a dating sample if such indications were identified. However, such examination cannot guarantee that old wood (and especially long-dead wood) is not present within the dating sequence (samples were also subject to wood species analysis; Eichhorn and Humphris, The use of charcoal in Kushite iron production, under review).

Ninety-seven radiocarbon dates are presented here. At Meroe, 82 dates originate from 15 trenches excavated in 5 slag mounds, and at Hamadab 15 dates derive from 5 trenches excavated in 4 slag mounds. Depending on the respective stratigraphy exposed and the occurrence of charcoal samples within, the number of dates varies across trenches. In some cases, only two or three dates could be obtained from one trench, sometimes deriving from only one or two metallurgical contexts. In trenches containing a more extensive stratigraphic sequence, the number increases up to a maximum of 17 dates.

In this paper, radiocarbon dates are stated according to Bayliss (2009, p. 124: fn. 2): "BP" refers to the measured ${ }^{14} \mathrm{C}$ ages; calibrated ${ }^{14} \mathrm{C}$ ages are given as "calBC" or "calAD"; dates derived from Bayesian modelling are given as "calBC" or "calAD." Within the description of the results and in the discussion section, we more generally use the terms of "century $\mathrm{BC}$ " or "AD" (omitting "cal") when addressing the results of our Bayesian modelling. All other dates, stated as dates/centuries "BC" or "AD" for example in the introduction section, refer to estimated or known historic calendar dates, unless quoted differently.

All charcoal samples were dated at the National Science Foundation Accelerator Mass Spectrometry Laboratory of the University of Arizona. The $\delta^{13} \mathrm{C}$ value was measured on a VG isotech dual inlet stable isotope mass spectrometer with high precision. The values were measured with respect to NIST 4990B, Oxalic Acid I, and are referenced to vPDB. All dated samples are presented in Appendices A 01-07, which provide an overview of the sample locations and contexts in stratigraphic top-down sequence, conventional BP ages and relevant laboratory information.

All BP ages were calibrated in OxCal v. 4.2.4 (Bronk Ramsey 2009a), using the IntCal 13 calibration curve (Reimer et al. 2013). The results of all single calibrations shown in Appendices A are presented in the $95.4 \%$ confidence intervals of the probability distributions. Additionally the mean, sigma and median values are noted. To present a potentially improved chronological sequence, the BP ages were modelled using Bayesian chronological analysis functions provided in $\mathrm{OxCal}$ (Bronk Ramsey 2009a; cf. F. Weninger et al. 2010, p. 963). We apply particular models to assess the validity of the dates against the visible stratigraphy (due to the complicated nature of the depositional sequences of the slag mounds) and to eliminate inverse dates when they may be the result of old wood; and thus to produce a plausible (if conservative at this early stage of the research), dating sequence for the production of iron in the Meroe region. The models are based on stratigraphic constraints (i.e., sample $\mathrm{A}<\mathrm{B}<\mathrm{C}$ ) related to the order of events (Bronk Ramsey 2009a, p. 342). Depending on the number and origin of the samples within the 
stratigraphy, we created sequences (one sample per context: $\mathrm{A}<\mathrm{B}<\mathrm{C}<\mathrm{D}$ ); sequences with (internal) phases (more than one sample/date from same context: $\mathrm{A}<[\mathrm{B} \mid$ $\mathrm{C}]<\mathrm{D}$ ); or sequential phases models (multiple phases, all contexts defined as individual phases with hiatuses in between: $[\mathrm{A}|\mathrm{B}| \mathrm{C}]<[\mathrm{D}]<[\mathrm{E} \mid \mathrm{F}]$ ); for an overview of the calibration models, see Bronk Ramsey 2009a. Additionally for some models, multiple dates deriving from the same context or sample were combined before modelling, using the $R_{-}$Combine function in $\mathrm{OxCal}$ (see Bronk Ramsey 2009b, pp. 1039-1040). The exception relates to specific dates obtained from the final phase of use of the furnace workshop excavated at slag mound MIS6. Here, in addition to the application of a sequence with final phase model and a sequential phases model, we use the $R$ _Combine function across contexts associated with the final use of the workshop space, regarding these contexts as relating to the same point in time (hence representing the same stratigraphic unit).

Creating stratigraphically constrained models is based on the assumption that the relative order or position of contexts is consecutive, in absolute chronological terms. We thereby simplistically need to assume that the unknown real age of the charcoal samples maintains the equivalent relative chronological order of the contexts. Therefore, initially only samples with stratigraphically plausible BP ages were selected for modelling. BP ages which were comparably too early in the sequence, causing inverse date successions, were rejected as outliers due to the potential for old wood and the resulting influence over the results of other samples, even if the modelled results and agreement indices they produced were in agreement with the models. Following initial modelling, further potential outliers identified by their insufficient agreement index (Bronk Ramsey 2009b, pp. 1024-1025) were neglected. All identified and potential outliers are marked in the tables of Appendix A. It could be suggested that in disregarding samples we consider as potential outliers, we have been overly cautious in our data handling. However, we feel that as a presentation of a new radiocarbon chronology for iron production in the Meroe region, it is important here to remain cautious of samples we feel may be problematic for reasons discussed above. As this research progresses and further excavations are carried out at Meroe, and as more radiocarbon dates become available, the chronological sequences presented here may well be refined to include samples we currently consider to be outliers. By listing all radiocarbon dates and highlighting those we have removed during the process of producing this new chronology, we provide opportunity for others to fully consider this chronology in light of all of the data generated so far.

As mentioned above, stratigraphic correlation of contexts was usually only possible within a single trench, and therefore the modelling and resulting chronology is based mainly upon stratigraphy within each trench. However, where the relative horizontal development of the slag mounds was observed stratigraphically between trenches, in particular by the declination of layers in the metallurgical deposits, their absolute horizontal chronology was possible to deduce from differences in the dating across trenches. Because the modelling of radiocarbon dates here is based on and limited to the opportunity to establish stratigraphic constraints and thus depends on the respective neighbouring dates within the stratigraphic sequence, there is the potential for quite different $c a l B C / A D$ results for stratigraphically uncorrelated samples from different trenches, despite their almost equivalent BP ages.

Although it is reasonable to impose stratigraphic constraints on the ordering of the radiocarbon dates, whether these dates in regards to modelling reflect sequences of individual independent events in time, or whether the sequences as a whole represent coherent groups (phases) of events (see Bronk Ramsey 2009a, pp. 342, 346), is difficult to assess, as is the distribution of the events over time (e.g., uniform, normal, exponential; see Bronk Ramsey 2009a, pp. 342-346). Except for trench MIS4-3-13 (see below), we generally use the uniform phase model (Bronk Ramsey 2009a, pp. 343-345). For archaeological stratigraphy such as being considered here, this is the most common and appropriate model type because it considers the distribution of events (dates) within the phase(s), i.e., the stratigraphic layers (as opposed to Gaussian distribution). Single or multiple groups (with internal phases) of events are delineated in OxCal by start/end events (boundaries) for the internal grouping and for the whole model sequence (see Bronk Ramsey 2009a, pp. 342-346). However, due to the potentially haphazard nature of the slag mound formation and the number and location of the trenches considered here, the stratigraphy revealed so far is incomplete regarding the "outer" start/end events for each slag mound and for iron production in general. Thus, 
Table 1 a and b Unmodelled and modelled earliest and latest radiocarbon dates from slag mound MIS4 at Meroe

\begin{tabular}{|c|c|c|c|c|c|c|c|c|c|c|c|c|c|c|}
\hline \multicolumn{15}{|c|}{$\begin{array}{c}{ }^{14} \text { C Dates Meroe: MIS4 - earliest and latest Dates } \\
\text { OxCal v. 4.2.4 (Bronk Ramsey 2009a), Curve IntCal13 (Reimer et al. 2013) }\end{array}$} \\
\hline $\begin{array}{l}\text { Fieldwork Sample } \\
\text { Details }\end{array}$ & \multicolumn{2}{|c|}{$\begin{array}{l}\text { Laboratory } \\
\text { Data }\end{array}$} & \multicolumn{6}{|c|}{ Unmodelled Calibration calBC } & \multicolumn{6}{|c|}{$\begin{array}{l}\text { Bayesian Modelling (per trench) calBC } \\
\text { (1) Sequence (single samples) } \\
\text { (2) Sequence with Phase } \\
\text { (2 Dates from sample AA102873) } \\
\text { (3) Sequence with R_Combine Date } \\
\text { (of sample AA102873) } \\
\text { (4) Sequential Phases } \\
\text { (2 Dates from sample AA102873) } \\
\text { (5) Sequential Phases with R_Combine Date } \\
\text { (of sample AA102873) } \\
\text { (6) Sequential Phases in "Open Sequence" } \\
\text { (2 Dates from sample AA102873) } \\
\text { (7) Sequential Phases with R_Combine Date } \\
\text { in "Open Sequence" (of sample AA102873) }\end{array}$} \\
\hline $\begin{array}{c}\text { Trench/Section/Context } \\
\text { in stratigraphic top-down } \\
\text { sequence per trench } \\
\end{array}$ & AA \# & \begin{tabular}{|c|}
${ }^{14}$ C Age \\
BP \\
$\pm 1 \sigma$ \\
\end{tabular} & $\begin{array}{r}95.4 \% \\
\text { ranges } \\
\end{array}$ & from & to & $\mu$ & $\sigma$ & $\mathbf{m}$ & \begin{tabular}{|r|}
$95.4 \%$ \\
ranges \\
\end{tabular} & from & to & $\mu$ & $\sigma$ & m \\
\hline MIS4-4-13/W/4082 & AA102877 & \begin{tabular}{|c|}
2,176 \\
\pm 39
\end{tabular} & $\begin{array}{r}91.2 \\
4.2 \\
\end{array}$ & $\begin{array}{l}-366 \\
-142\end{array}$ & $\begin{array}{l}-148 \\
-112\end{array}$ & -256 & \pm 72 & -259 & \begin{tabular}{|r|} 
(1) 94.8 \\
0.6
\end{tabular} & $\begin{array}{l}-381 \\
-129\end{array}$ & $\begin{array}{l}-159 \\
-122\end{array}$ & -283 & \pm 67 & -305 \\
\hline MIS4-5-13/W/4098 & AA102879 & $\begin{array}{c}2,220 \\
\pm 39\end{array}$ & 95.4 & -387 & -197 & -283 & \pm 55 & -281 & (1) 95.4 & -346 & -182 & -261 & \pm 45 & -262 \\
\hline MIS4-5-13/W/4100 & AA102881 & $\begin{array}{c}2,163 \\
\pm 39\end{array}$ & 95.4 & -361 & -96 & -238 & \pm 80 & -227 & (1) 95.4 & -364 & -204 & -303 & \pm 44 & -316 \\
\hline MIS4-4-13/W/4085 & AA102878 & $\begin{array}{c}2,404 \\
\pm 40\end{array}$ & $\begin{array}{r}14.3 \\
4.8 \\
76.3\end{array}$ & $\begin{array}{l}-750 \\
-668 \\
-590\end{array}$ & $\begin{array}{l}-683 \\
-639 \\
-396\end{array}$ & -523 & \pm 101 & -491 & \begin{tabular}{rr|} 
(1) & 5.4 \\
& 2.0 \\
88.0
\end{tabular} & $\begin{array}{l}-739 \\
-665 \\
-561\end{array}$ & $\begin{array}{l}-687 \\
-643 \\
-390\end{array}$ & -483 & \pm 81 & -461 \\
\hline \multirow{6}{*}{ MIS4-3-13/N/4069 } & \multirow{6}{*}{ AA102874 } & \multirow{6}{*}{$\begin{array}{c}2,422 \\
\pm 35\end{array}$} & \multirow{6}{*}{$\begin{array}{r}17.8 \\
6.2 \\
0.4 \\
71.0\end{array}$} & \multirow{6}{*}{$\begin{array}{l}-751 \\
-669 \\
-622 \\
-591\end{array}$} & \multirow{6}{*}{$\begin{array}{l}-683 \\
-638 \\
-617 \\
-402\end{array}$} & \multirow{6}{*}{-540} & \multirow{6}{*}{ \pm 104} & \multirow{6}{*}{-508} & (2) 95.4 & -530 & -399 & -451 & \pm 42 & -440 \\
\hline & & & & & & & & & $\begin{array}{|lr|}\text { (3) } & 0.3 \\
& 95.1 \\
\end{array}$ & $\begin{array}{l}-657 \\
-552\end{array}$ & $\begin{array}{l}-652 \\
-397\end{array}$ & -463 & \pm 54 & -450 \\
\hline & & & & & & & & & (4) 95.4 & -545 & -400 & -462 & \pm 46 & -451 \\
\hline & & & & & & & & & (5) 95.4 & -546 & -400 & -462 & \pm 47 & -452 \\
\hline & & & & & & & & & \begin{tabular}{|l|} 
(6) 95.4 \\
\end{tabular} & -564 & -399 & 474 & \pm 50 & 466 \\
\hline & & & & & & & & & $\begin{array}{|rr|}\text { (7) } & 1.9 \\
& 93.5 \\
\end{array}$ & $\begin{array}{l}-664 \\
-592\end{array}$ & $\begin{array}{l}-643 \\
-401\end{array}$ & -489 & \pm 60 & -481 \\
\hline \multirow{3}{*}{ MIS4-3-13/N/4075 (humates) } & \multirow{3}{*}{ AA102873 } & \multirow{3}{*}{$\begin{array}{c}2,424 \\
\pm 40\end{array}$} & \multirow{3}{*}{$\begin{array}{r}19.1 \\
9.5 \\
66.8\end{array}$} & \multirow{3}{*}{$\begin{array}{l}-752 \\
-669 \\
-593\end{array}$} & \multirow{3}{*}{$\begin{array}{l}-682 \\
-613 \\
-402\end{array}$} & \multirow{3}{*}{-551} & \multirow{3}{*}{ \pm 107} & \multirow{3}{*}{-519} & \begin{tabular}{rr|} 
(2) & 8.5 \\
& 4.9 \\
& 1.6 \\
& 80.4 \\
\end{tabular} & $\begin{array}{l}-741 \\
-668 \\
-628 \\
-596 \\
\end{array}$ & $\begin{array}{l}-685 \\
-636 \\
-611 \\
-408 \\
\end{array}$ & -526 & \pm 86 & -505 \\
\hline & & & & & & & & & $\begin{array}{r}\text { (4) } 14,5 \\
11.9 \\
69.0\end{array}$ & $\begin{array}{l}-745 \\
-669 \\
-596\end{array}$ & $\begin{array}{l}-683 \\
-609 \\
-418\end{array}$ & -558 & \pm 91 & -532 \\
\hline & & & & & & & & & \begin{tabular}{|r|} 
(6) 63.6 \\
31.8
\end{tabular} & $\begin{array}{l}-761 \\
-601\end{array}$ & $\begin{array}{l}-607 \\
-465\end{array}$ & -636 & \pm 89 & -658 \\
\hline \multirow{3}{*}{ MIS4-3-13/N/4075 (charcoal) } & \multirow{3}{*}{ AA102873 } & \multirow{3}{*}{$\begin{array}{c}2,473 \\
\pm 46\end{array}$} & \multirow{3}{*}{$\begin{array}{r}94.8 \\
0.6\end{array}$} & & & & & & $\begin{array}{|rr|}(2) & 1.0 \\
& 94.4 \\
\end{array}$ & $\begin{array}{l}-738 \\
-724 \\
\end{array}$ & $\begin{array}{l}-729 \\
-411 \\
\end{array}$ & -548 & \pm 90 & -534 \\
\hline & & & & -420 & -416 & -612 & \pm 99 & -617 & \begin{tabular}{|l|} 
(4) 95.4 \\
\end{tabular} & -741 & -421 & -560 & \pm 91 & -538 \\
\hline & & & & & & & & & \begin{tabular}{|l|} 
(6) 95.4 \\
\end{tabular} & -786 & -509 & -653 & \pm 79 & -661 \\
\hline MIS4-3-13/N/4075 & & & 24.9 & -753 & -682 & & & & \begin{tabular}{|r|} 
(3) 12.1 \\
5.8 \\
1.7 \\
75.9 \\
\end{tabular} & $\begin{array}{l}-747 \\
-668 \\
-628 \\
-595 \\
\end{array}$ & $\begin{array}{l}-684 \\
-637 \\
-613 \\
-411 \\
\end{array}$ & -540 & \pm 92 & -518 \\
\hline $\begin{array}{l}\text { (humates+charcoal) } \\
\text { R_Combine Date }\end{array}$ & AA102873 & $\begin{array}{c}2,445 \\
\pm 31\end{array}$ & $\begin{array}{l}13.6 \\
57.0\end{array}$ & $\begin{array}{l}-670 \\
-594\end{array}$ & $\begin{array}{l}-611 \\
-409\end{array}$ & $-57 c$ & \pm 105 & -554 & \begin{tabular}{r|} 
(5) 15.8 \\
12.3 \\
67.3
\end{tabular} & $\begin{array}{l}-747 \\
-669 \\
-596\end{array}$ & $\begin{array}{l}-683 \\
-610 \\
-418\end{array}$ & -561 & \pm 93 & -536 \\
\hline & & & & & & & & & \begin{tabular}{|r|} 
(7) 75.7 \\
19.7
\end{tabular} & $\begin{array}{l}-765 \\
-599\end{array}$ & $\begin{array}{l}-605 \\
-491\end{array}$ & -661 & \pm 78 & -690 \\
\hline
\end{tabular}

whereas internal individual events or groupings (phases) are constrained by neighbouring contexts and dates, the models as a whole should be regarded as open sequences as opposed to closed sequences with a defined start and end event (see below).

Following Bayliss' (2009, p. 134) suggestion, sensitivity analyses were conducted by constructing and using alternative models where possible or meaningful regarding the availability of dated samples and the number of contexts involved, and the results were compared.
As a general rule, the modelled dates did not markedly differ between the different uniform phase models delineated by start/end boundaries. The results of Bayesian modelling are presented in the results section below: separately for each slag mound investigated, and in one table for the furnace workshop at MIS6 and the site of Hamadab respectively (Tables 1, 2, 3, 4, 5, 6 and 7, a: table format; b: graphic output). Regarding the furnace workshop at MIS6, and the site of Hamadab, all modelled dates apart from outliers are noted. Regarding 
Table 1 (continued)

T 01b - Model 1

Trench MIS4-4-13 (top) and MIS4-5-13 (bottom): Sequence (single samples)
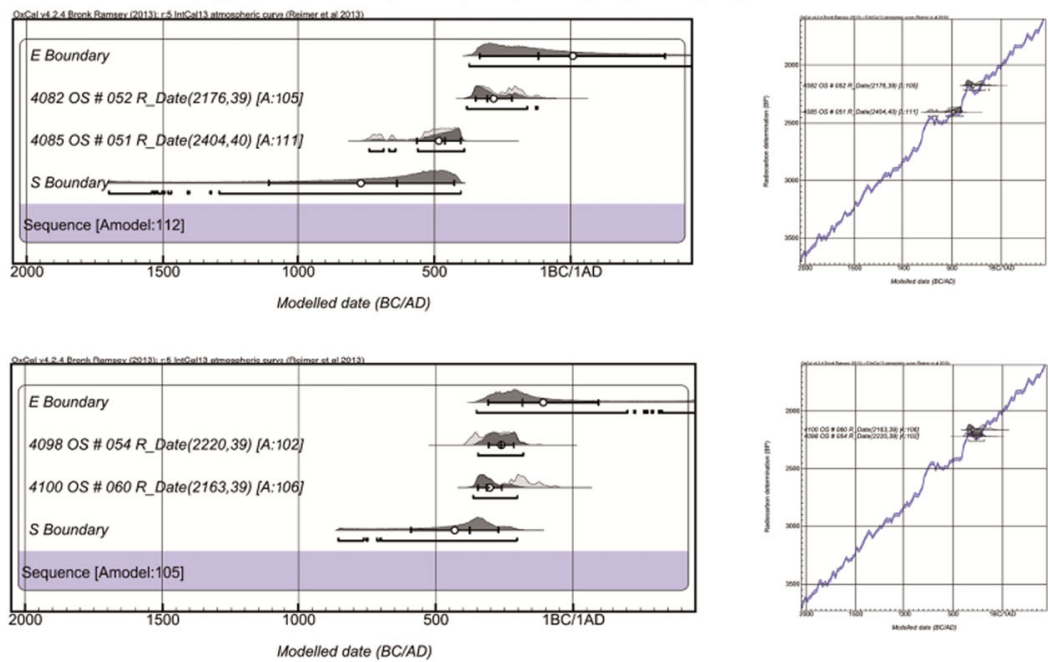

Table 01b - Model 2

Trench MIS4-3-13: Sequence with Phase (2 dates from 1 sample taken from context 4075)
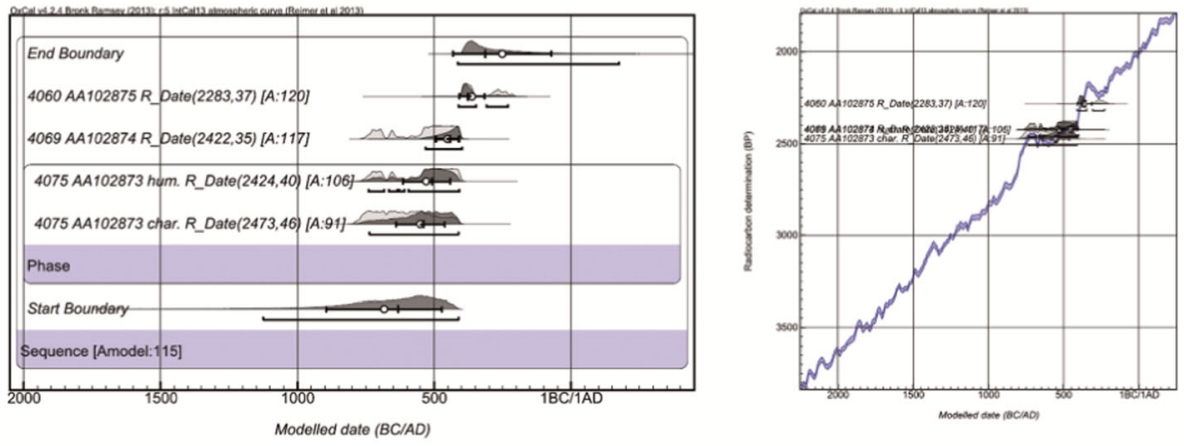

T 01b - Model 3

Trench MIS4-3-13: Sequence with R_Combine Date (2 dates from 1 sample taken from context 4075 )
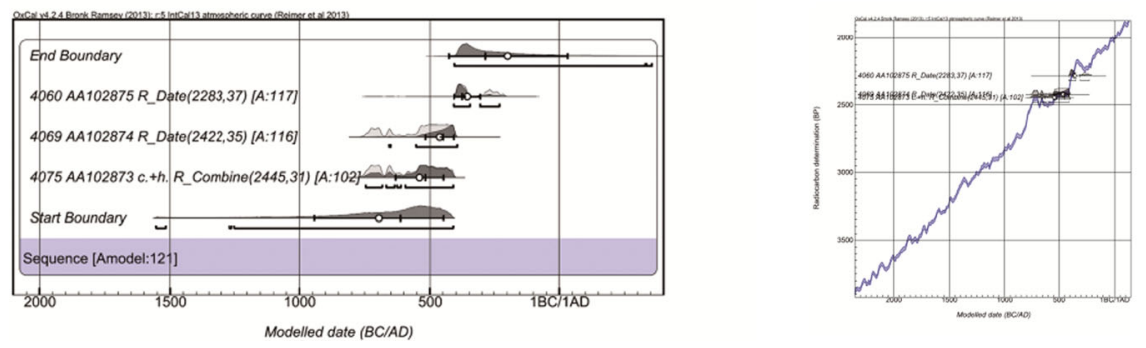

the other mounds presented here, the majority of the modelled dates that lay between the earliest and latest date ranges, or that were identified as potential outliers, are omitted. The results follow in chronological order from the earliest to latest slag mound, comparing the
95.4\% confidence intervals of the calibrated and modelled dates. Regarding trench MIS4-3-13, which provided the earliest dates for iron production at Meroe so far, additional normal distribution models inserting outer sigma_boundaries (see Bronk Ramsey 2009a, p. 
Table 1 (continued)

Table 01b - Model 4

Trench MIS4-3-13: Sequential Phases (2 dates from 1 sample taken from context 4075)
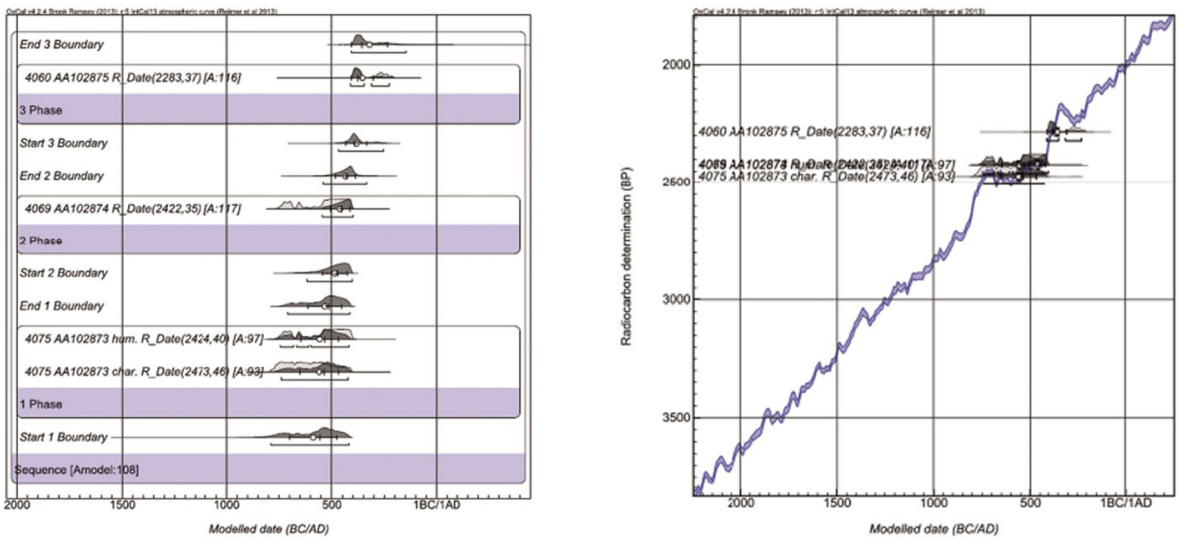

Table 01b - Model 5

Trench MIS4-3-13: Sequential Phases with R_Combine Date (2 dates from 1 sample taken from context 4075)
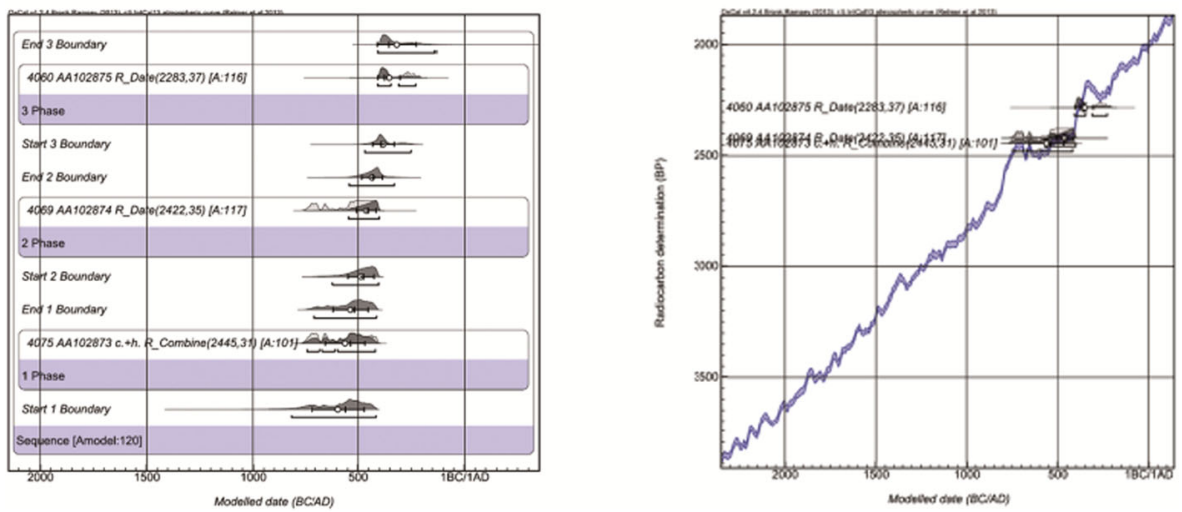

Table 01b - Model 6

Trench MIS4-3-13: Sequential Phases in Open Sequence (2 dates from 1 sample taken from context 4075 )
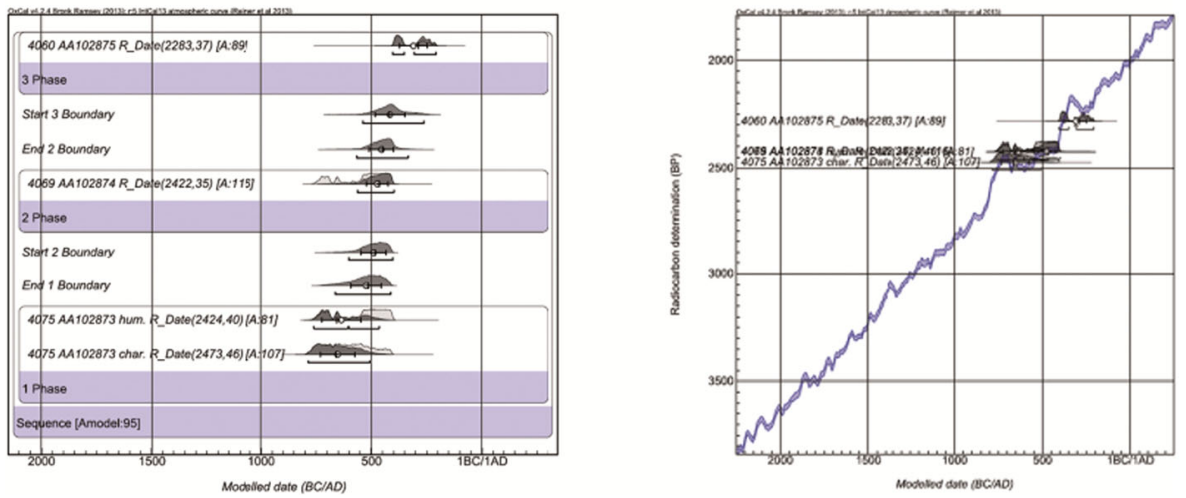
346) and open sequence models without defined outer start/end boundaries were tested (see Table 1a and b). The results of the normal distribution model and the open sequence model again do not differ markedly. Of course, these models are biased to longer spans, which can lead to an overestimation of the spread of the dating series (cf. Bronk Ramsey 2009a, p. 339 and Bayliss, 2009, pp. 130-131). However, considering one of the essential research questions, to examine the maximum potential time of the beginning of iron production, these models aim to test the credibility of the early spans of the $95.4 \%$ ranges. This is especially so of the earliest dates from trench MIS4-3-13, since the outer boundaries shift at least the earliest and latest modelled dates, assigning the entire sequence to a shorter time span. Considering the results of the investigations by Steier and Rom (2000) and B. Weninger et al. (2011), it can be questioned whether grouped or ungrouped modelling better reflects reality, at least in the case of slag mounds with respect to the current state of research.

It is important to note that the wide spread, and the similarity of the $95.4 \%$ confidence intervals of some of the calibrated and the modelled dates and their partially bi- or multimodal shape and "separation into multiple disjunct regions" (B. Weninger et al. 2011, p. 8), in the here relevant time periods, predominantly reflects the wiggled and sometimes plateau-like (c. 730-420 calBC, c. 140-210 and 260-310 calAD), and in parts even reverse (c. 330-260 calBC, 440-530 calAD) course of the calibration curve (IntCal 13; Reimer et al. 2013). This is known to be problematic for calibration (Steier and Rom 2000, p. 187; Walanus 2009, p. 433; B. Weninger et al. 2011, p. 7: Fig. 4): "independent of the real age of the sample." Within such plateaus, "the resulting probability distribution of the calendar age is roughly the same for samples of any true age" (Walanus 2009 , p. 433) as well as for Bayesian modelling of ${ }^{14} \mathrm{C}$ dates (see Steier and Rom 2000, pp. 187-195).

\section{Results}

MIS4

Overview

MIS4, the largest slag mound at Meroe and probably one of the largest in Africa (especially in its original entirety), is situated east of the city of Meroe (here defined as the extent of the site surrounded by a modern fence, as shown in Fig. 1). The diameter of MIS4 measures c. $60 \mathrm{~m} \mathrm{~N}-\mathrm{S}$. According to the results of the excavations, the maximum height preserved above natural ground is c. $5 \mathrm{~m}$. Five trenches measuring $2 \times 2 \mathrm{~m}$ were excavated at MIS4, four of them running in a W-E oriented row from the highest point down to the eastern foot of the mound at a distance of $4 \mathrm{~m}$ from each other (trenches MIS4-1-13 to MIS4-4-13). A fifth trench, MIS4-5-13, was situated $13.5 \mathrm{~m}$ south of the westernmost trench of this row, inside a depression. Due to the instability of the metallurgical deposits at MIS4, even those trenches positioned at higher locations in the mound were only excavated to a maximum depth of $2.05 \mathrm{~m}$.

\section{Stratigraphy and Formation of the Mound}

The natural calcrete surface was only reached in the lowest, easternmost trench (4). All metallurgical layers exposed in trenches 1-4 sloped often steeply down in a southern direction (see Figs. 2 and 3, west sections). In the uppermost trench (1), the layers started to slope in a western direction but became horizontal by trench 2 (see Fig. 2, north section), and began to slope towards the east by trench 3. Considering the stratigraphy in the W-E direction, the core of the mound may well be situated to the north of trench 2. In trench 5, all layers ran horizontally and were not related to the steeply sloping layers running to the south in trenches $1-4$, demonstrating that the mound was not created in a uniform manner. MIS4 therefore seems to have been created at least partially from north to south, which does not mean, however, that the metallurgical debris was brought from the south (see also Bradley 1984, p. 202). Such insights could indicate where furnace workshops were located, although no such structures were identified during geophysical investigations around MIS4.

\section{Chronology}

The radiocarbon dates (see Table 1a and b, and Appendix A 01) indicate that MIS4, and in particular trench MIS4-3-13, contains the earliest slag deposits known at Meroe so far (see also Fig. 4). The formation of MIS4 began at the latest in the fifth century $\mathrm{BC}$ and probably earlier. In particular, 
Table 2 a and $\mathbf{b}$ Unmodelled and modelled earliest and latest radiocarbon dates from slag mound MIS2 at Meroe

\begin{tabular}{|c|c|c|c|c|c|c|c|c|c|c|c|c|c|c|}
\hline \multicolumn{15}{|c|}{$\begin{array}{c}{ }^{14} \text { C Dates Meroe: MIS2 - earliest and latest Dates } \\
\text { OxCalv. 4.2.4 (Bronk Ramsey 2009a), Curve IntCal13 (Reimer et al. 2013) }\end{array}$} \\
\hline $\begin{array}{l}\text { Fieldwork Sample } \\
\text { Details }\end{array}$ & $\begin{array}{l}\text { Labor } \\
\text { Dat }\end{array}$ & $\begin{array}{l}\text { atory } \\
\text { ta }\end{array}$ & & nmod & led C & librat & $\mathrm{ncal}$ & & & Bayes & an $M$ & $\begin{array}{l}\text { Jellin } \\
\text { I Phas }\end{array}$ & alBC & \\
\hline \begin{tabular}{|c|} 
Trench/Section/Context \\
in stratigraphic top-down \\
sequence per trench \\
\end{tabular} & AA\# & \begin{tabular}{|c|}
${ }^{14} \mathrm{CAge}$ \\
$\mathrm{BP}$ \\
$\pm 1 \sigma$ \\
\end{tabular} & $\begin{array}{r}95.4 \% \\
\text { ranges }\end{array}$ & from & to & $\mu$ & $\sigma$ & $\mathrm{m}$ & $\begin{array}{r}95.4 \% \\
\text { ranges } \\
\end{array}$ & from & to & $\mu$ & $\sigma$ & $\mathrm{m}$ \\
\hline MIS2-1-13/W/2010 & AA102863 & $\begin{array}{c}2,218 \\
\pm 41\end{array}$ & \begin{tabular}{l|}
64.8 \\
30.6 \\
\end{tabular} & $\begin{array}{l}-430 \\
-320\end{array}$ & $\begin{array}{l}-347 \\
-207\end{array}$ & -349 & \pm 65 & -375 & 95.4 & -382 & -193 & -280 & \pm 56 & -276 \\
\hline MIS2-1-13/W/2013 & AA102864 & $\begin{array}{c}2,301 \\
\pm 41\end{array}$ & 95.4 & -388 & -193 & -282 & \pm 57 & -281 & \begin{tabular}{r|}
20.0 \\
75.0 \\
0.3 \\
\end{tabular} & $\begin{array}{l}-322 \\
-431 \\
-452\end{array}$ & $\begin{array}{l}-227 \\
-345 \\
-445\end{array}$ & -362 & \pm 54 & -379 \\
\hline
\end{tabular}

\section{T 02b}

Trench MIS2-1-13: Sequential Phases
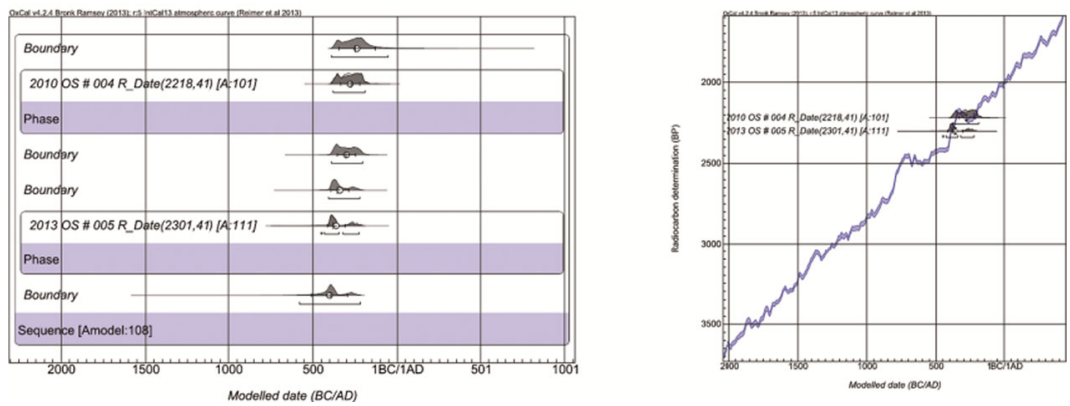

comparing open sequence models with sequences delineated by outer boundaries, more than $75 \%$ of the probability distribution of the earliest date from MIS4 (trench MIS4-3-13, context 4075, R_Combine date) are positioned either between 765 and 605 calBC (open sequence) or between 595 and 411 calBC. In the closed sequences, a smaller distribution lies in the eighth century BC. The early distributions should not be disregarded, both because of the horizontal stratigraphy described above, and because of the significant depth of metallurgical deposits underlying the earliest dates. Weninger et al. (2011, p. 17) also support the significance of the small eighth-century BC distribution: "In the past, radiocarbon dating probability was taken to represent a value (number) attributed to each interval of the calendric time-scale. The new quantum probability is again a number. However, it is no longer valid to assume that the larger this number, the more probable the dating."

Deposition of metallurgical debris at MIS4 continued to the fourth century $\mathrm{BC}$ and possibly to the second half of the second century BC. The stratigraphically deduced formation of MIS4 is reflected by the results of radiocarbon dating. The fact that only one early, but not the earliest date comes from trench 2, which is located in the core area of the mound according to the W-E stratigraphy, can be explained by the higher distance from the base of the mound in trench 2 compared to trench 3 .

MIS2

\section{Overview}

MIS2 is located to the southeast of MIS4. On top of this mound is found the remains of a Meroitic sandstone building known here as the Kiosk (NE36-O/3-J-4.600 after Hinkel 2000, Fig. 1; see also Hinkel 1977). MIS2 measures c. $20 \mathrm{~m} \mathrm{~N}-\mathrm{S}$ (as visible from the surface). Trench MIS2-1-13, measuring $2 \times 2 \mathrm{~m}$, was positioned along the southern outer wall of the Kiosk, dug to the natural ground level which was reached at a depth of c. $1.50 \mathrm{~m}$ below present surface or $1.90 \mathrm{~m}$ below the preserved height of the Kiosk wall. The thickness of the metallurgical deposits exposed in the trench is $1.20 \mathrm{~m}$, resting on the natural calcrete surface. The metallurgical deposits of this mound may have been an additional c. $40 \mathrm{~cm}$ higher and previously removed, presumably by Garstang in the early 1900s. 
Table 3 a and b Unmodelled and modelled earliest and latest radiocarbon dates from slag mound MIS3 at Meroe

\begin{tabular}{|c|c|c|c|c|c|c|c|c|c|c|c|c|c|c|}
\hline \multicolumn{15}{|c|}{$\begin{array}{c}{ }^{14} \text { C Dates Meroe: MIS3 - earliest and latest Dates } \\
\text { OxCal v. 4.2.4 (Bronk Ramsey 2009a), Curve IntCal13 (Reimer et al. 2013) }\end{array}$} \\
\hline \multirow{2}{*}{ 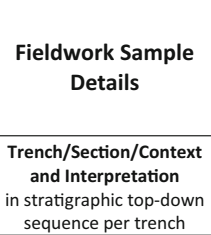 } & \multicolumn{2}{|c|}{$\begin{array}{l}\text { Laboratory } \\
\text { Data }\end{array}$} & \multicolumn{6}{|c|}{ Unmodelled Calibration calBC } & \multicolumn{6}{|c|}{$\begin{array}{l}\text { Bayesian Modelling (per trench) calBC } \\
\text { (1) Sequence } \\
\text { (2) Sequence with Phases } \\
\text { (single samples or multiple samples from } \\
\text { same context) }\end{array}$} \\
\hline & AA\# & $\begin{array}{c}{ }^{14} \mathrm{C} \text { Age } \\
\text { BP } \\
\pm 1 \sigma\end{array}$ & $\begin{array}{r}95.4 \% \\
\text { ranges }\end{array}$ & from & to & $\mu$ & $\sigma$ & m & $\begin{array}{r}95.4 \% \\
\text { ranges }\end{array}$ & from & to & $\mu$ & $\sigma$ & m \\
\hline MIS3-1-13/E/3015: slag layer & AA102888 & $\begin{array}{c}2,192 \\
\pm 39 \\
\end{array}$ & $\begin{array}{r}95.0 \\
0.4 \\
\end{array}$ & $\begin{array}{l}-381 \\
-127\end{array}$ & $\begin{array}{l}-164 \\
-123 \\
\end{array}$ & -270 & \pm 63 & -277 & (1) 95.4 & -373 & -213 & -307 & \pm 44 & -317 \\
\hline $\begin{array}{l}\text { MIS3-2-14/E/3095: } \\
\text { stratigraphically latest slag } \\
\text { layer in trench 2, upper part } \\
\text { of the depression }\end{array}$ & AA106765 & $\begin{array}{c}2,231 \\
\pm 28\end{array}$ & $\begin{array}{l}20.5 \\
74.9\end{array}$ & $\begin{array}{l}-385 \\
-327\end{array}$ & $\begin{array}{l}-341 \\
-204\end{array}$ & -285 & \pm 51 & -277 & (2) $\begin{aligned} & 13.6 \\
& 81.8\end{aligned}$ & $\begin{array}{l}-375 \\
-308\end{array}$ & $\begin{array}{l}-348 \\
-207\end{array}$ & -272 & \pm 43 & -264 \\
\hline $\begin{array}{l}\text { MIS3-2-14/E/3095: } \\
\text { stratigraphically latest slag } \\
\text { layer in trench 2, upper part } \\
\text { of the depression }\end{array}$ & AA106766 & $\begin{array}{c}2,249 \\
\pm 24\end{array}$ & $\begin{array}{l}31.6 \\
63.8\end{array}$ & $\begin{array}{l}-391 \\
-311\end{array}$ & $\begin{array}{l}-350 \\
-209\end{array}$ & -297 & \pm 56 & -279 & (2) \begin{tabular}{rl|}
13.4 \\
& 82.0
\end{tabular} & $\begin{array}{l}-374 \\
-299\end{array}$ & $\begin{array}{l}-351 \\
-210\end{array}$ & -273 & \pm 38 & -259 \\
\hline $\begin{array}{l}\text { MIS3-2-14/E/3086: lower fill } \\
\text { layer in depression between } \\
\text { core areas of mound }\end{array}$ & AA106759 & $\begin{array}{l}2,229 \\
\pm 51+\end{array}$ & 95.4 & -396 & -183 & -284 & \pm 63 & -283 & (2) 95.4 & -378 & -246 & -309 & \pm 38 & -306 \\
\hline $\begin{array}{l}\text { MIS3-3-14/E/3138: } \\
\text { stratigraphically latest slag } \\
\text { layer in trench } 3\end{array}$ & AA106757 & $\begin{array}{c}2,266 \\
\pm 25\end{array}$ & $\begin{array}{l}69.6 \\
25.8\end{array}$ & $\begin{array}{l}-403 \\
-291\end{array}$ & $\begin{array}{l}-354 \\
-231\end{array}$ & -345 & \pm 56 & -373 & $\begin{array}{r}\text { (2) } 94.0 \\
1.4 \\
\end{array}$ & $\begin{array}{l}-381 \\
-266\end{array}$ & $\begin{array}{l}-356 \\
-262\end{array}$ & -361 & \pm 26 & -367 \\
\hline $\begin{array}{l}\text { MIS3-3-14/E/3138: } \\
\text { stratigraphically latest slag } \\
\text { layer in trench } 3\end{array}$ & AA106758 & $\begin{array}{c}2,284 \\
\pm 27\end{array}$ & $\begin{array}{r}50.9 \\
42.2 \\
2.2\end{array}$ & $\begin{array}{l}-399 \\
-297 \\
-221\end{array}$ & $\begin{array}{l}-352 \\
-228 \\
-211\end{array}$ & -320 & \pm 59 & -355 & \begin{tabular}{r|} 
(2) 93.6 \\
1.8 \\
\end{tabular} & $\begin{array}{l}-381 \\
-267\end{array}$ & $\begin{array}{l}-356 \\
-262\end{array}$ & -361 & \pm 26 & -367 \\
\hline $\begin{array}{l}\text { MIS3-3-14/E/3058: charcoal } \\
\text { layer in northern core of } \\
\text { mound }\end{array}$ & AA106747 & $\begin{array}{c}2,231 \\
\pm 29\end{array}$ & $\begin{array}{l}20.7 \\
74.7\end{array}$ & $\begin{array}{l}-385 \\
-327\end{array}$ & $\begin{array}{l}-341 \\
-204\end{array}$ & -285 & \pm 51 & -278 & (2) $\begin{array}{r}93.5 \\
1.9\end{array}$ & $\begin{array}{l}-387 \\
-273\end{array}$ & $\begin{array}{l}-361 \\
-268\end{array}$ & -368 & \pm 25 & -374 \\
\hline $\begin{array}{l}\text { MIS3-3-14/E/3054: early slag } \\
\text { layer in northern core of } \\
\text { mound }\end{array}$ & AA106742 & $\begin{array}{c}2,229 \\
\pm 25\end{array}$ & $\begin{array}{l}18.6 \\
76.8\end{array}$ & $\begin{array}{l}-382 \\
-325\end{array}$ & $\begin{array}{l}-343 \\
-204\end{array}$ & -283 & \pm 50 & -275 & \begin{tabular}{|r|} 
(2) 93.0 \\
\\
2.4
\end{tabular} & $\begin{array}{l}-389 \\
-274\end{array}$ & $\begin{array}{l}-361 \\
-267\end{array}$ & -368 & \pm 25 & -374 \\
\hline $\begin{array}{l}\text { MIS3-3-14/E/3044: earliest } \\
\text { metallurgical layer in trench } 3\end{array}$ & AA106745 & $\begin{array}{c}2,249 \\
\pm 28 \\
\end{array}$ & 95.4 & -405 & -177 & -294 & \pm 69 & -288 & \begin{tabular}{rl|} 
(2) 92.8 \\
2.6
\end{tabular} & $\begin{array}{l}-392 \\
-275 \\
\end{array}$ & $\begin{array}{l}-360 \\
-267 \\
\end{array}$ & -369 & \pm 25 & -375 \\
\hline $\begin{array}{l}\text { MIS 3-3-14/E/3044: earliest } \\
\text { metallurgical layer in trench } 3\end{array}$ & AA106744 & $\begin{array}{c}2,275 \\
\pm 58 \\
\end{array}$ & $\begin{array}{l}62.8 \\
32.6\end{array}$ & $\begin{array}{l}-400 \\
-292\end{array}$ & $\begin{array}{l}-353 \\
-231 \\
\end{array}$ & -334 & \pm 58 & -367 & \begin{tabular}{rl|}
$(2)$ & 92.7 \\
2.7 \\
\end{tabular} & $\begin{array}{l}-392 \\
-275 \\
\end{array}$ & $\begin{array}{l}-360 \\
-267 \\
\end{array}$ & -369 & \pm 25 & -375 \\
\hline \begin{tabular}{l|} 
MIS3-2-14/E/3071: earliest \\
metallurgical layer in trench 2
\end{tabular} & AA106763 & $\begin{array}{c}2,222 \\
\pm 30\end{array}$ & 95.4 & -377 & -204 & -283 & \pm 51 & 279 & (2) 95.4 & -386 & -253 & -335 & \pm 39 & -351 \\
\hline $\begin{array}{l}\text { MIS3-2-14/E/3071: earliest } \\
\text { metallurgical layer in trench } 2\end{array}$ & AA106764 & $\begin{array}{c}2207(+) \\
\pm 50(+)\end{array}$ & $\begin{array}{r}94.7 \\
0.7\end{array}$ & $\begin{array}{l}-394 \\
-129\end{array}$ & $\begin{array}{l}-163 \\
-120\end{array}$ & -273 & \pm 67 & -277 & (2) 95.4 & -389 & -252 & -335 & \pm 38 & -346 \\
\hline $\begin{array}{l}\text { MIS3-2-14/E/3070: pre- } \\
\text { metallurgy layer }\end{array}$ & AA106762 & $\begin{array}{c}2,304 \\
\pm 23\end{array}$ & \begin{tabular}{r|}
93.1 \\
2.3
\end{tabular} & $\begin{array}{l}-406 \\
-272\end{array}$ & $\begin{array}{l}-359 \\
-261\end{array}$ & -379 & \pm 31 & -388 & \begin{tabular}{|r|} 
(2) 85.6 \\
9.8
\end{tabular} & $\begin{array}{l}-405 \\
-285\end{array}$ & $\begin{array}{l}-358 \\
-257\end{array}$ & -368 & \pm 40 & -382 \\
\hline
\end{tabular}

\section{Stratigraphy and Mound Formation}

The formation of this mound was not uniform. The lower layers of the metallurgical deposit gently sloped towards north, whereas the upper layers bent additionally to the south, thereby cutting off the lower layers. The latest layers rested discordantly on top of this southward slope.

\section{Chronology}

Three charcoal samples (see Appendix A 02) collected from the western section of trench MIS2-1-13 provided two reliable dates. The apparently unreliable uppermost date was inverse, perhaps due to old wood or mixing of materials during the construction of the building. According to the modelled results (Table $2 \mathrm{a}$ and $\mathrm{b}$ ), metallurgical deposition began between the second half of the fifth and second half of the third century BC, and ended at the latest at the beginning of the second century $\mathrm{BC}$ (Fig. 4). It is quite possible that neither the earliest nor the latest parts of the slag mound are represented in this trench, partly due to the limited excavations so far undertaken at MIS2.

\section{MIS3}

\section{Overview}

MIS3 is situated south of MIS4 and SW of MIS2. Following Garstang's excavations (1911, pp. 21-23), this slag mound is known as the location of Meroe's Apedemak Temple (designation NE-36-O/3-J-4.600 after Hinkel 2000, Fig. 1; see also Hinkel 1977). 
Table 3 (continued)

Table 03b - Model 1

Trench MIS3-1-13: Sequence
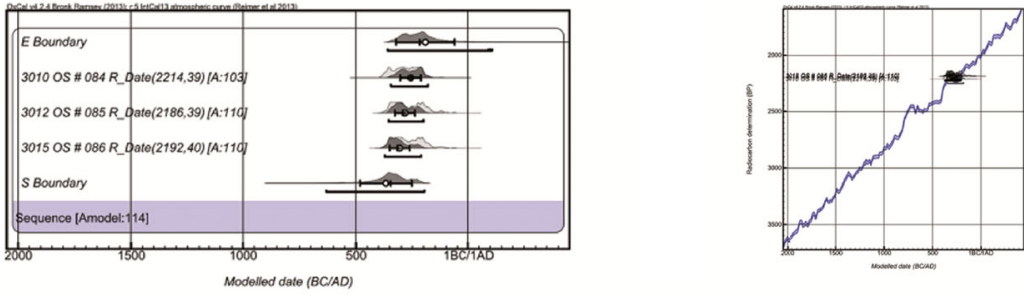

Table 03b - Model 2

Trench MIS3-2-13: Sequence with Phases

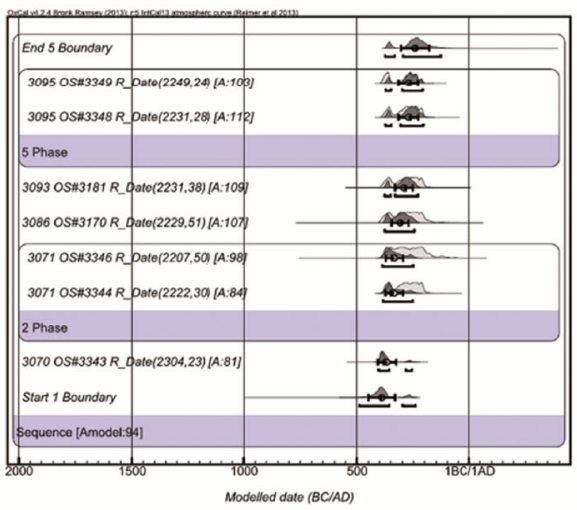

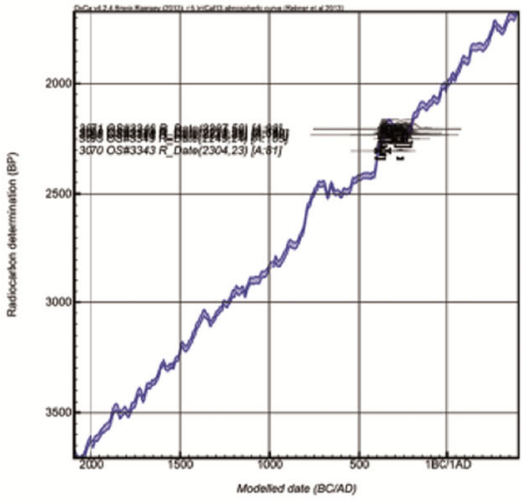

Table 03b - Model 2

Trench MIS3-3-13: Sequence with Phases
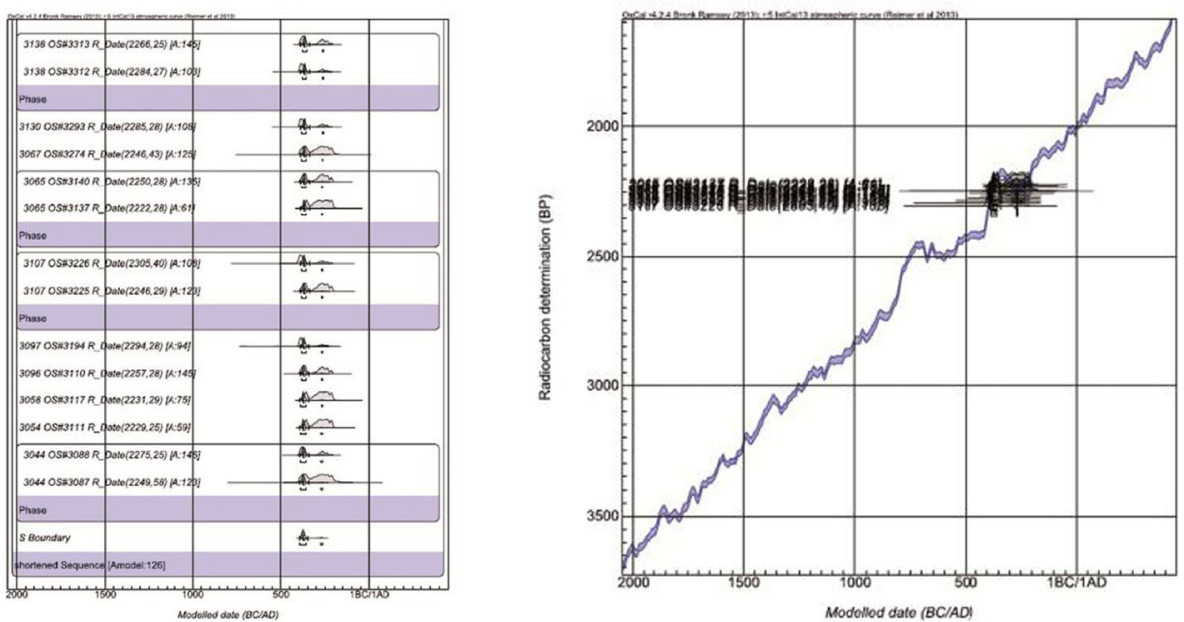

This temple was erected during Meroitic times using the slag mound as platform, raising the structure (like the Kiosk), above its surroundings. MIS3 measures c. $30 \mathrm{~m} \mathrm{~N}-\mathrm{S}$ (as visible from the surface). The maximum height of the mound above the natural

ground is $3.20 \mathrm{~m}$, although the upper layers of the mound appear to have been levelled during the construction of the temple and so the metallurgical deposits could have been originally higher. The thickness of the metallurgical deposits is $2.90 \mathrm{~m}$, 
Table 4 a and $\mathbf{b}$ Unmodelled and modelled earliest and latest radiocarbon dates from slag mound MIS1/2 at Meroe

\begin{tabular}{|c|c|c|c|c|c|c|c|c|c|c|c|c|c|c|}
\hline \multicolumn{15}{|c|}{$\begin{array}{c}{ }^{14} \text { C Dates Meroe: MIS1/2 - earliest and latest Dates } \\
\text { OxCalv. 4.2.4 (Bronk Ramsey 2009a), Curve Intcal13 (Reimer et al. 2013) }\end{array}$} \\
\hline $\begin{array}{l}\text { Fieldwork Sample } \\
\text { Details }\end{array}$ & \multicolumn{2}{|c|}{$\begin{array}{l}\text { Laboratory } \\
\text { Data }\end{array}$} & \multicolumn{6}{|c|}{ Unmodelled Calibration calBC } & \multicolumn{6}{|c|}{$\begin{array}{l}\text { Bayesian Modelling calBC } \\
\text { one Sequence across two Trenches }\end{array}$} \\
\hline $\begin{array}{l}\text { Trench/Section/Context } \\
\text { in horizontal stratigraphic } \\
\text { top-down sequence } \\
\text { across two trenches }\end{array}$ & AA \# & $\begin{array}{c}{ }^{14} \mathrm{C} \text { Age } \\
\text { BP } \\
\pm 1 \sigma\end{array}$ & $\begin{array}{r}95.4 \% \\
\text { ranges }\end{array}$ & from & to & $\mu$ & $\sigma$ & m & $\begin{array}{r}95.4 \% \\
\text { ranges }\end{array}$ & from & to & $\mu$ & $\sigma$ & $\mathrm{m}$ \\
\hline $\begin{array}{l}\text { MIS1/2-2-13/N/2022 upper } \\
\text { part }\end{array}$ & AA102883 & $\begin{array}{c}2,085 \\
\pm 39\end{array}$ & 95.4 & -201 & 2 & -110 & \pm 58 & -108 & $\begin{array}{r}0.8 \\
94.6\end{array}$ & $\begin{array}{l}-339 \\
-211\end{array}$ & $\begin{array}{l}-325 \\
-37\end{array}$ & -143 & \pm 53 & -150 \\
\hline $\begin{array}{l}\text { MIS1/2-3-13/N/2020 lower } \\
\text { part }\end{array}$ & AA102885 & $\begin{array}{c}2,190 \\
\pm 39\end{array}$ & $\begin{array}{r}95.2 \\
0.2\end{array}$ & $\begin{array}{l}-379 \\
-127\end{array}$ & $\begin{array}{l}-164 \\
-124\end{array}$ & -269 & \pm 64 & -277 & 95.4 & -368 & -208 & -297 & \pm 45 & -305 \\
\hline
\end{tabular}

\section{T 04b}

Trench MIS1/2-13: One Sequence Across Two Trenches
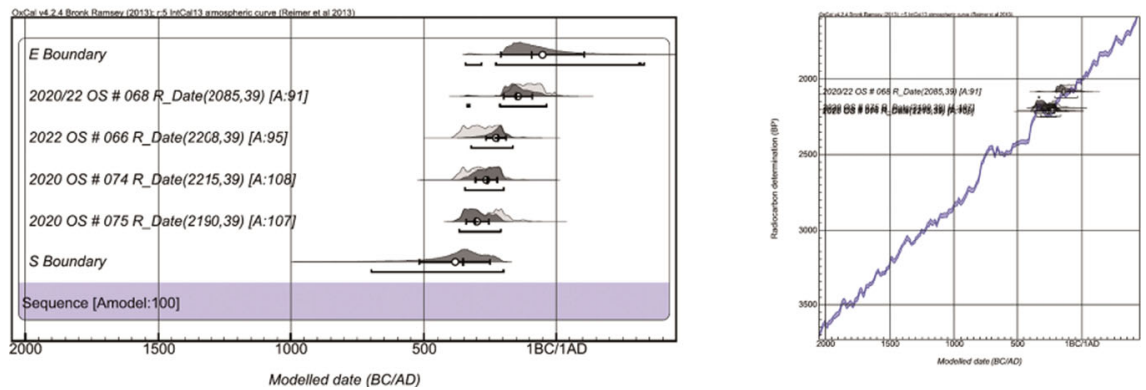

underlain by non-metallurgical layers before natural calcrete is found.

Three trenches (MIS3-1-13, MIS3-2-14 and MIS33-14) were excavated at MIS3. Trench 1, measuring $1.80 \mathrm{~m}(\mathrm{NNE}-\mathrm{SSW}) \times 1 \mathrm{~m}$ and $1.90 \mathrm{~m}$ in depth, was situated in the NW corner between the temple and its temenos wall. Trenches 2 and 3 ran in one row from inside the temple towards north. Trench 2, located inside the temple, was $2 \times 2 \mathrm{~m}$ and reached a depth of $3.20 \mathrm{~m}$. Trench $3 \mathrm{ran}$ in a continual line from trench 2 , from the northern side of the temple wall, and measured $2.5 \times 16 \mathrm{~m}$ towards NNE. The first $10 \mathrm{~m}$ of this trench cut through the metallurgical deposits (thus the actual diameter of the slag mound was originally much larger that the c. $25 \mathrm{~m}$ visible at surface level today).

\section{Stratigraphy and Mound Formation}

The formation of MIS3 can be reconstructed in more detail than MIS4 and MIS2 due to the more extensive nature of the excavations. Similar to the other slag mounds, MIS3 probably developed from multiple smaller core mounds to its final shape. One of these core mounds was revealed in the southern end of trench 3 which is characterised by layers which sloped down towards the south and then bent to slope north, thus initially forming a mound. This core mound was built up at least as high as the present upper surface of MIS3, before deposition was continued northwards, forming a horizontal stratigraphy of layers which uniformly sloped north. The sequence towards south is interrupted by a trench excavated presumably by Garstang (not visible from the current surface, which was also the case at MIS2), and by the foundations of the northern temple wall. In trench 2, all layers initially sloped south, from the northern core. These rested on top of slag layers which started to raise south, probably towards an earlier core. A depression was formed between these cores, filled by later metallurgical deposits. These layers simultaneously sloped down to the east, suggesting that the actual centre of the core mound(s) was located to the west of trench 2 and 3. Running under the core and depression were sandy horizontal layers containing only small amounts of, or no slag. The thickness of these layers was c. $40 \mathrm{~cm}$. They separate an even earlier slag layer (trench 2: context 3071; trench 3: context 3044) from the actual slag mound deposit. This earlier metallurgical horizontal layer of c. $20 \mathrm{~cm}$ thickness was situated c. $20 \mathrm{~cm}$ above the undulating surface of the natural calcrete ground, underlain by non-metallurgical sandy layers with embedded calcrete lumps. In trench 
Table 5 a and b Unmodelled and modelled radiocarbon dates from the furnace workshop at MIS6 at Meroe

\begin{tabular}{|c|c|c|c|c|c|c|c|c|c|c|c|c|c|c|}
\hline \multicolumn{15}{|c|}{$\begin{array}{c}{ }^{14} \text { C Dates Meroe: MIS6 Furnace Workshop - modelled Dates } \\
\text { OxCalv. 4.2.4 (Bronk Ramsey 2009a), Curve IntCal13 (Reimer et al. 2013) }\end{array}$} \\
\hline $\begin{array}{l}\text { Fieldwork Sample } \\
\text { Details }\end{array}$ & \multicolumn{2}{|c|}{$\begin{array}{l}\text { Laboratory } \\
\text { Data }\end{array}$} & \multicolumn{6}{|c|}{ Unmodelled Calibration calAD } & \multicolumn{6}{|c|}{$\begin{array}{l}\text { Bayesian Modelling calAD } \\
\text { (1) Sequence with R_Combine Date of final Phase } \\
\text { (2) Sequence (single dates) with final Phase } \\
\text { (multiple contexts and dates) } \\
\text { (3) Sequential Phases } \\
\text { (single and multiple contexts and dates) }\end{array}$} \\
\hline $\begin{array}{l}\text { Trench/Section/Context } \\
\text { and Interpretation } \\
\text { in functional phases and } \\
\text { stratigraphic top-down } \\
\text { sequence }\end{array}$ & AA\# & $\begin{array}{l}{ }^{14} \mathrm{C} \text { Age } \\
\text { BP } \\
\pm 1 \sigma\end{array}$ & $\begin{array}{r}95.4 \% \\
\text { ranges }\end{array}$ & from & to & $\mu$ & $\sigma$ & m & \begin{tabular}{|r|}
$95.4 \%$ \\
ranges \\
\end{tabular} & from & to & $\mu$ & $\sigma$ & m \\
\hline $\begin{array}{l}\text { R_Combine Date of } \\
\text { final workshop phase } \\
\text { comprising } 5 \text { samples from } \\
\text { contexts } \\
\text { FW233+013+219+224 }\end{array}$ & $\begin{array}{l}\text { AA106737 } \\
\text { AA105311 } \\
\text { AA106735 } \\
\text { AA106736 } \\
\text { AA106740 }\end{array}$ & $\begin{array}{c}1632 \\
\pm 14\end{array}$ & $\begin{array}{r}91.7 \\
2.9 \\
0.7\end{array}$ & $\begin{array}{l}385 \\
495 \\
521\end{array}$ & $\begin{array}{l}430 \\
509 \\
526\end{array}$ & 415 & \pm 26 & 411 & (1) 95.4 & 399 & 430 & 418 & \pm 15 & 417 \\
\hline \multirow{2}{*}{$\begin{array}{l}\text { MIS6-1-14/FW233 = final } \\
\text { phase: last dump of smithing } \\
\text { and smelting debris }\end{array}$} & \multirow{2}{*}{ AA106737 } & \multirow{2}{*}{$\begin{array}{c}1,669 \\
\pm 28\end{array}$} & \multirow{2}{*}{$\begin{array}{r}3.1 \\
92.3\end{array}$} & \multirow{2}{*}{$\begin{array}{l}350 \\
379\end{array}$} & \multirow{2}{*}{$\begin{array}{l}368 \\
540\end{array}$} & \multirow{2}{*}{451} & \multirow{2}{*}{ \pm 53} & \multirow{2}{*}{446} & (2) 95.4 & 401 & 426 & 414 & \pm 6 & 414 \\
\hline & & & & & & & & & (3) 95.4 & 403 & 426 & 415 & \pm 7 & 415 \\
\hline \multirow{2}{*}{$\begin{array}{l}\text { MIS6-1-14/FW013 = final } \\
\text { phase: remains of latest } \\
\text { smithing activity }\end{array}$} & \multirow{2}{*}{ AA105311 } & \multirow{2}{*}{$\begin{array}{c}1,642 \\
\pm 32\end{array}$} & \multirow{2}{*}{$\begin{array}{l}79.8 \\
15.6\end{array}$} & \multirow{2}{*}{$\begin{array}{l}333 \\
485\end{array}$} & \multirow{2}{*}{$\begin{array}{l}474 \\
535\end{array}$} & \multirow{2}{*}{414} & \multirow{2}{*}{ \pm 53} & \multirow{2}{*}{406} & (2) 95.4 & 401 & 428 & 414 & \pm 7 & 415 \\
\hline & & & & & & & & & (3) 95.4 & 403 & 426 & 415 & \pm 7 & 416 \\
\hline \multirow{2}{*}{$\begin{array}{l}\text { MIS6-1-14/FW219 = final } \\
\text { phase: last working surface in } \\
\text { brick-lined pit }\end{array}$} & \multirow{2}{*}{ AA106735 } & \multirow{2}{*}{$\begin{array}{c}1,619 \\
\pm 36\end{array}$} & \multirow{2}{*}{$\begin{array}{r}3.1 \\
92.3\end{array}$} & \multirow{2}{*}{$\begin{array}{l}350 \\
379\end{array}$} & \multirow{2}{*}{$\begin{array}{l}368 \\
540\end{array}$} & \multirow{2}{*}{451} & \multirow{2}{*}{ \pm 53} & 446 & (2) 95.4 & 400 & 430 & 415 & \pm 8 & 415 \\
\hline & & & & & & & & 440 & (3) 95.4 & 403 & 427 & 415 & \pm 7 & 416 \\
\hline MIS6-1-14/FW224 = final & AA106736 & 1,609 & 95.4 & 388 & 540 & 463 & +48 & 464 & (2) 95.4 & 400 & 430 & 415 & \pm 8 & 415 \\
\hline in furnace & $\mid A+100700$ & \pm 33 & 93.4 & 300 & 340 & 405 & 140 & 404 & (3) 95.4 & 403 & 427 & 415 & \pm 7 & 416 \\
\hline MIS6-1-14/FW224 = final & AA106740 & 1,616 & 58.5 & 390 & 475 & $456->>$ & +47 & 443 & (2) 95.4 & 400 & 430 & 415 & \pm 8 & 415 \\
\hline in furnace & $A R 100740$ & \pm 24 & 36.9 & 485 & 536 & 450 & 141 & 443 & (3) 95.4 & 403 & 426 & 415 & \pm 7 & 416 \\
\hline MIS6-1-14/FW258: second & & & & & & & & & (1) 95.4 & 398 & 427 & 414 & \pm 13 & 414 \\
\hline (not the latest) phase of & AA106738 & $\begin{array}{c}1,619 \\
\pm 25\end{array}$ & $\begin{array}{l}61.2 \\
34.2\end{array}$ & $\begin{array}{l}387 \\
484\end{array}$ & $\begin{array}{l}475 \\
536\end{array}$ & 452 & \pm 48 & 430 & (2) 95.4 & 399 & 422 & 410 & \pm 6 & 411 \\
\hline & & & & & & & & & (3) 95.4 & 399 & 424 & 412 & \pm 7 & 412 \\
\hline & & & & & & & & & (1) 95.4 & 394 & 425 & 411 & \pm 11 & 410 \\
\hline $\begin{array}{l}\text { MIS6-1-14/FW267: first phase } \\
\text { of workshop floor layer }\end{array}$ & AA106739 & $\begin{array}{c}1,614 \\
\pm 25\end{array}$ & $\begin{array}{l}56.5 \\
38.9\end{array}$ & $\begin{array}{l}392 \\
484\end{array}$ & $\begin{array}{l}475 \\
536\end{array}$ & 459 & \pm 47 & 454 & (2) 95.4 & 396 & 422 & 409 & \pm 6 & 409 \\
\hline & & & & & & & & & (3) 95.4 & 396 & 422 & 409 & \pm 7 & 409 \\
\hline MIS & & & 4.9 & 345 & 372 & & & & (1) 95.4 & 386 & 424 & 406 & \pm 12 & 406 \\
\hline hearth remains predating & AA106741 & $\begin{array}{c}1,633 \\
\pm 24\end{array}$ & $\begin{array}{r}10.4 \\
2.4\end{array}$ & 453 & $\begin{array}{l}435 \\
470\end{array}$ & 426 & \pm 45 & 413 & (2) 95.4 & 392 & 421 & 407 & \pm 7 & 408 \\
\hline & & & 17.6 & 487 & 534 & & & & (3) 95.4 & 389 & 412 & 405 & \pm 9 & 406 \\
\hline
\end{tabular}

1 , the original stratification is intensely disturbed by the construction of the temple and its temenos wall, in particular because the temple foundations are deeper at its corner than in trenches 2 and 3. Therefore here, only the lowest parts of the metallurgical deposits were still in their original position, and also sloped north and slightly east. The natural ground was not reached in this trench.

\section{Chronology}

The stratigraphically lowest sample from MIS3 derives from the pre-metallurgical layer above the natural ground in trench 2 (see Table 3a and b; Appendices A 03a and $03 \mathrm{~b}$ ). This sample indicates that at least in the area of this trench, the metallurgical deposits were not created earlier than the beginning of the fourth century BC. The earliest metallurgical layer dates at the latest into the first half of the third century $\mathrm{BC}$, but overlaps the range of the date from the underlying pre-metallurgical context. Therefore, the metallurgical deposition at MIS3 could have originated in the early fourth century BC. The dates from the core area in trench 3 also fall into the early fourth to the first half of the third century BC. Somewhat later, at the earliest after the first quarter of fourth century $\mathrm{BC}$ and at the latest in the mid-third century $\mathrm{BC}$, the deposition of metallurgical debris in the depression between the northern and southern core mounds began. The latest dates vary between trenches. The stratigraphically latest dated metallurgical context in trench 3 at the northern end of the slag mound dates to the same time range as the early layers, between the early fourth and mid-third century BC. The dates from the middle part of the depression fill extend from the first half of the fourth to the end of the third century BC. The latest date from MIS3 comes from a stratigraphically low slag layer in trench 1 , located $1.80 \mathrm{~m}$ below present surface, dating between the mid-fourth and the end of the third century BC. This could indicate a horizontal development of MIS3 from the east to 
Table 5 (continued)

Table 05b - Model 1

MIS6 Furnace Workshop: Sequence With R_Combine Date of Final Phase
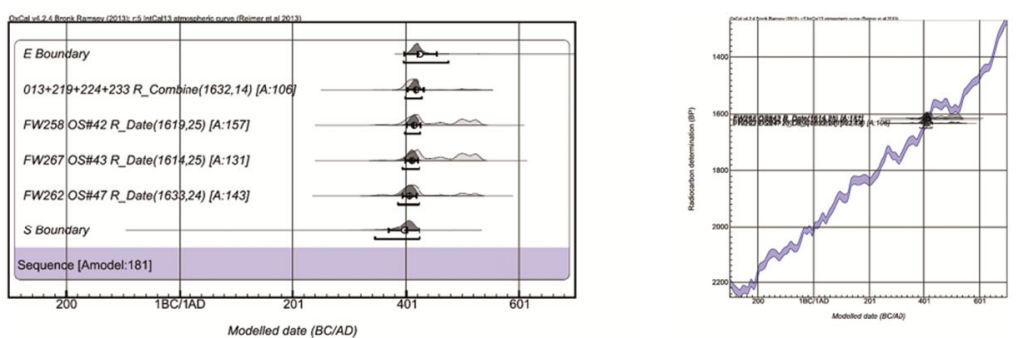

Table 05b - Model 2

MIS6 Furnace Workshop: Sequence With Final Phase
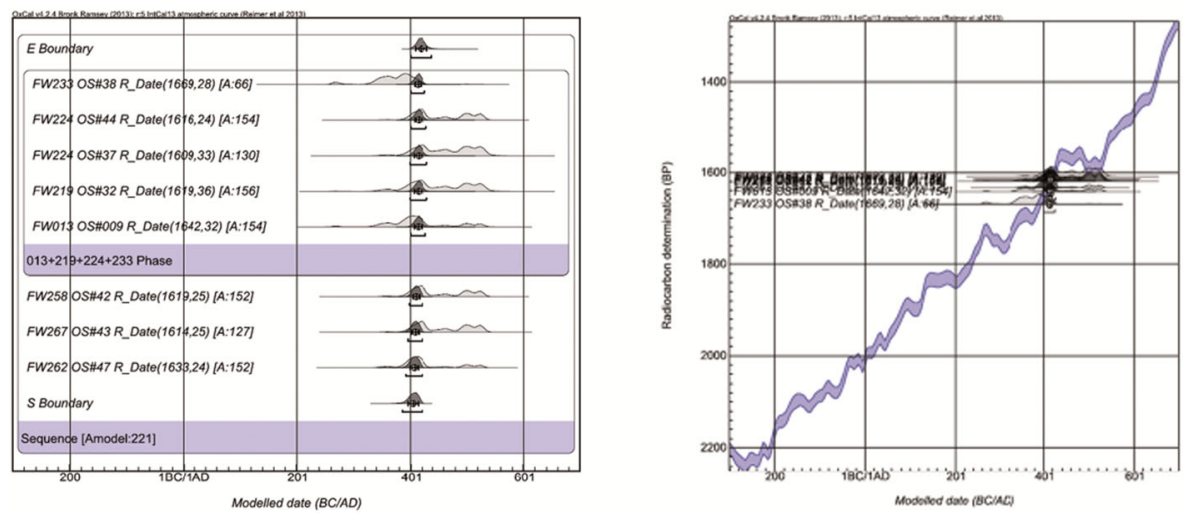

T 05b - Model 3

MIS6 Furnace Workshop: Sequential Phases
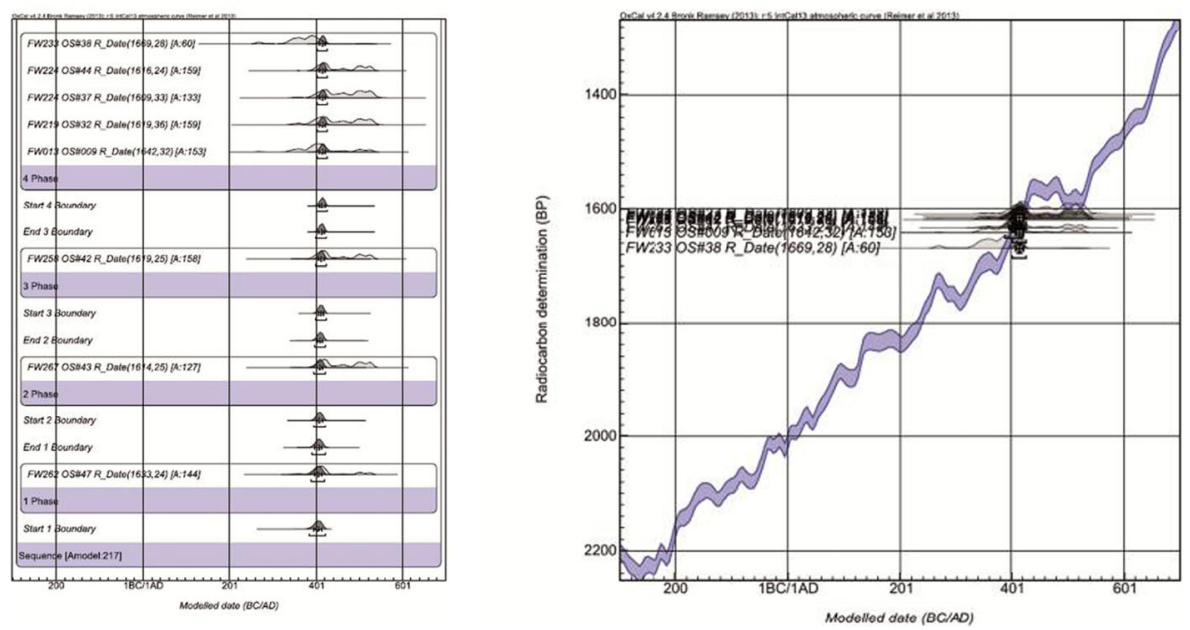

the west, but could also reflect the mixed nature of the slag deposits here due to the foundations dug during the construction of the temple. As noted above, the originally highest layers of this mound

were truncated to create a flat surface for the temple. If the latest dated iron production waste was contained within the truncated areas of MIS3, these are now impossible to access. 
Table 6 a and b Unmodelled and modelled earliest and latest radiocarbon dates from slag mound MIS6 at Meroe

\begin{tabular}{|c|c|c|c|c|c|c|c|c|c|c|c|c|c|c|}
\hline \multirow{3}{*}{\begin{tabular}{|c|} 
T 06a \\
$\begin{array}{c}\text { Fieldwork Sample } \\
\text { Details }\end{array}$ \\
$\begin{array}{c}\text { Trench/Section/Context } \\
\text { in stratigraphic top-down } \\
\text { sequence per trench }\end{array}$ \\
\end{tabular}} & \multicolumn{13}{|c|}{$\begin{array}{c}{ }^{14} \text { C Dates Meroe: MIS6 - earliest and latest Dates } \\
\text { Oxcalv. 4.2.4 (Bronk Ramsey 2009a), curve Intcally (Reimer et al. 2013) }\end{array}$} & \\
\hline & \multicolumn{2}{|c|}{$\begin{array}{l}\text { Laboratory } \\
\text { Data }\end{array}$} & \multicolumn{6}{|c|}{ Unmodelled Calibration calAD } & \multicolumn{6}{|c|}{$\begin{array}{c}\text { Bayesian Modelling (per trench) calAD } \\
\text { Sequences }\end{array}$} \\
\hline & AA\# & $\begin{array}{c}{ }^{14} \mathrm{C} \text { Age } \\
\text { BP } \\
\pm 1 \sigma\end{array}$ & $\begin{array}{r}95.4 \% \\
\text { ranges }\end{array}$ & from & to & $\mu$ & $\sigma$ & $\mathrm{m}$ & \begin{tabular}{|r|}
$95.4 \%$ \\
ranges
\end{tabular} & from & to & $\mu$ & $\sigma$ & $\mathrm{m}$ \\
\hline MIS6-3-14/S/63003 & AA105309 & $\begin{array}{l}1,582 \\
\pm 32 \\
\end{array}$ & 95.4 & 405 & 548 & 480 & \pm 41 & 482 & 95.4 & 410 & 540 & 467 & \pm 38 & 460 \\
\hline MIS6-3-14/E/63001 & AA105308 & $\begin{array}{c}1,613 \\
\pm 31\end{array}$ & 95.4 & 387 & 539 & 460 & \pm 48 & 459 & 95.4 & 396 & 517 & 440 & \pm 38 & 428 \\
\hline MIS6-3-14/W/63042 & AA105307 & $\begin{array}{c}1,611 \\
\pm 33 \\
\end{array}$ & 95.4 & 386 & 541 & 461 & \pm 48 & 462 & $\begin{array}{r}94.3 \\
1.1 \\
\end{array}$ & $\begin{array}{l}377 \\
489 \\
\end{array}$ & $\begin{array}{l}475 \\
499 \\
\end{array}$ & 415 & \pm 24 & 411 \\
\hline MIS6-2-14/E/62009 & AA105317 & $\begin{array}{c}1,640 \\
\pm 40\end{array}$ & $\begin{array}{r}0.8 \\
94.6\end{array}$ & $\begin{array}{l}266 \\
332\end{array}$ & $\begin{array}{l}271 \\
538\end{array}$ & 419 & \pm 62 & 410 & $\begin{array}{r}91.7 \\
3.4 \\
0.3 \\
\end{array}$ & $\begin{array}{l}340 \\
490 \\
520\end{array}$ & $\begin{array}{l}471 \\
512 \\
523\end{array}$ & 406 & \pm 39 & 402 \\
\hline MIS6-1W-14/W/61006T & AA105315 & $\begin{array}{c}1,642 \\
\pm 37 \\
\end{array}$ & $\begin{array}{l}77.0 \\
18.4 \\
\end{array}$ & $\begin{array}{l}332 \\
483 \\
\end{array}$ & $\begin{array}{l}477 \\
536\end{array}$ & 416 & \pm 59 & 407 & 95.4 & 341 & 465 & 403 & \pm 26 & 402 \\
\hline MIS6-4-14/S/64004 & AA105299 & $\begin{array}{c}1,658 \\
\pm 32\end{array}$ & $\begin{array}{r}3.4 \\
86.5 \\
5.6\end{array}$ & $\begin{array}{l}260 \\
325 \\
491\end{array}$ & $\begin{array}{l}280 \\
432 \\
531\end{array}$ & 387 & \pm 47 & 389 & 95.4 & 344 & 433 & 401 & \pm 26 & 402 \\
\hline MIS6-1W-14/W/61006Q & AA105314 & $\begin{array}{c}1,710 \\
\pm 32\end{array}$ & 95.4 & 250 & 399 & 328 & \pm 45 & 336 & $\begin{array}{l}13.5 \\
81.9 \\
\end{array}$ & $\begin{array}{l}258 \\
309\end{array}$ & $\begin{array}{l}303 \\
390\end{array}$ & 339 & \pm 33 & 345 \\
\hline MIS6-4-14/E/E4051 & AA105303 & $\begin{array}{c}1,740 \\
\pm 31\end{array}$ & 95.4 & 235 & 386 & 301 & \pm 43 & 299 & 95.4 & 255 & 387 & 327 & \pm 36 & 331 \\
\hline MIS6-3-14/W/63081 & AA105304 & \begin{tabular}{c|}
1,770 \\
\pm 31
\end{tabular} & 95.4 & 138 & 345 & 269 & \pm 51 & 276 & 95.4 & 235 & 384 & 310 & \pm 38 & 315 \\
\hline MIS6-2-14/N/62013 & AA105320 & $\begin{array}{c}1,783 \\
\pm 34\end{array}$ & 95.4 & 134 & 335 & 247 & \pm 58 & 247 & $\begin{array}{r}1.8 \\
93.6\end{array}$ & $\begin{array}{l}179 \\
205\end{array}$ & $\begin{array}{l}195 \\
383\end{array}$ & 292 & \pm 48 & 306 \\
\hline
\end{tabular}

Table 06b - Trench MIS6-1W-14

Sequence
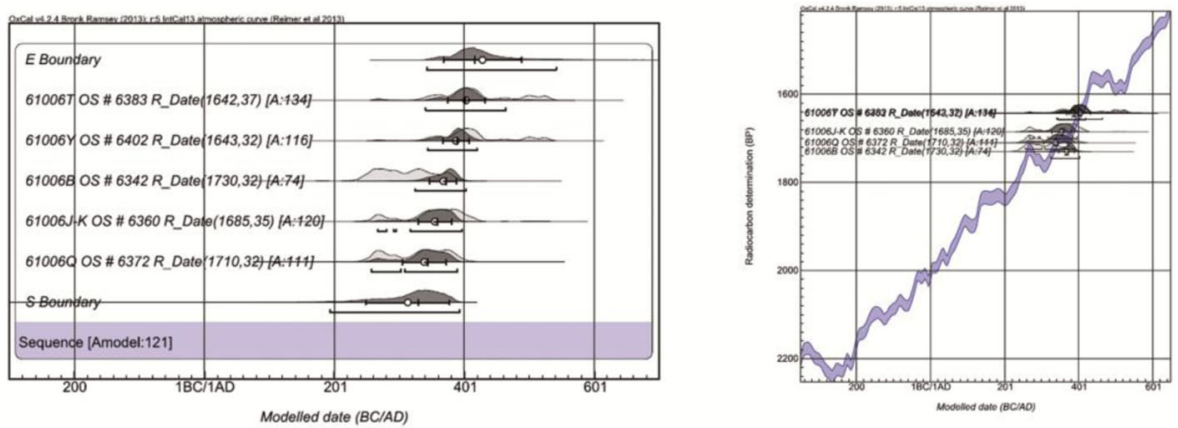

Table 06b - Trench MIS6-2-14

Sequence
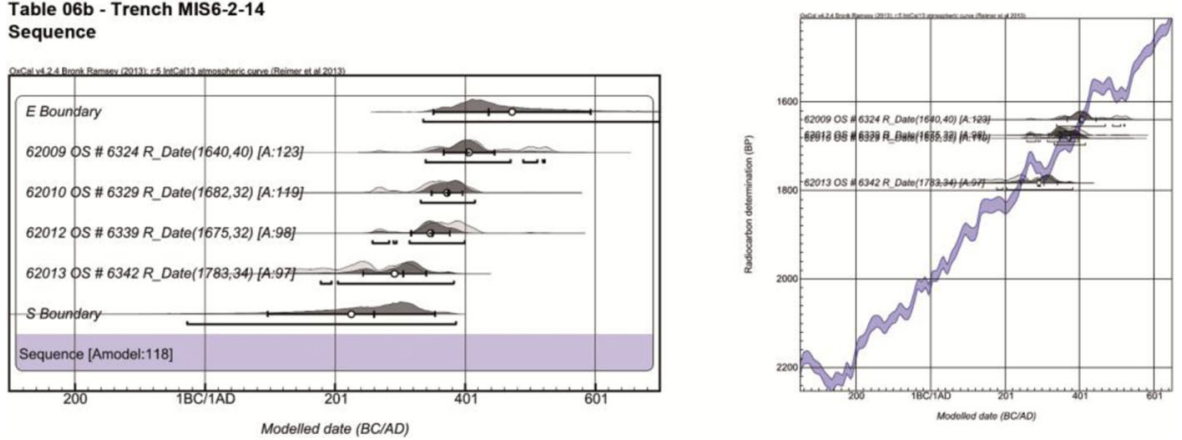
Table 6 (continued)

Table 06b - Trench MIS6-3-14

Sequence

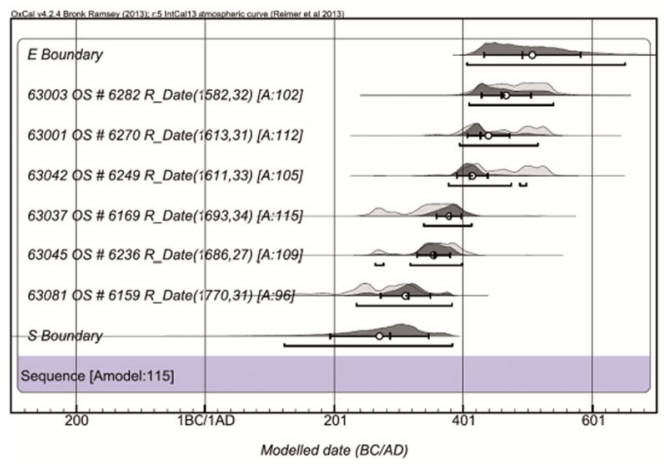

Table 06b - Trench MIS6-4-14

Sequence

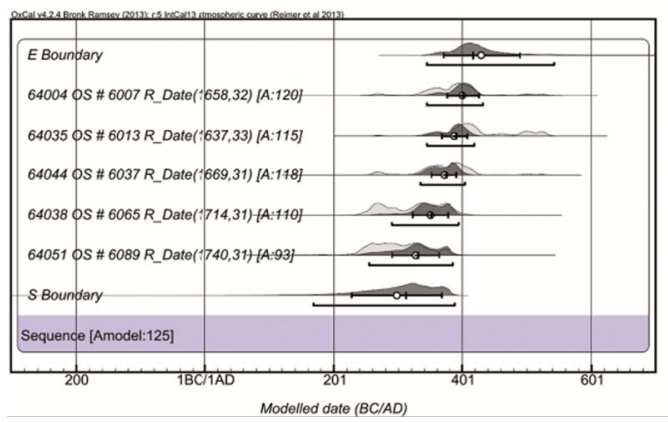

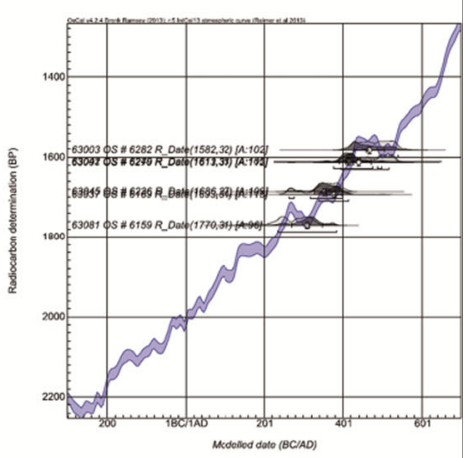

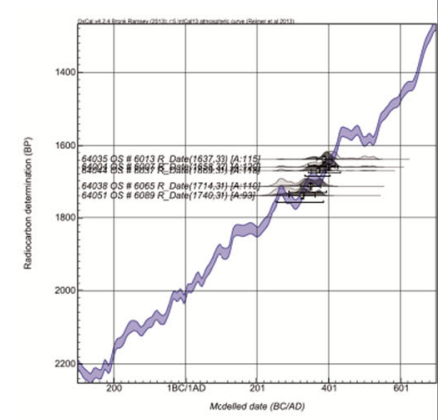

MIS1/2

\section{Overview and Stratigraphy}

MIS1/2 refers to the location between MIS1 and MIS2. Three $2 \times 2 \mathrm{~m}$ trenches were excavated running between the visible edges of MIS 1 and MIS 2 to test whether a subsurface stratigraphic relationship between the two mounds existed. These trenches reached a depth of no more than $1 \mathrm{~m}$ before the natural surface was encountered. The metallurgical deposits sloped towards the east and south, petering out at the southernmost trench closest to MIS1. The eastern sloping layers could be connected to MIS3. The samples from MIS1/2 (Appendix A 04) were collected from the northern and the middle trench, between which a stratigraphic relationship could be established.

\section{Chronology}

The modelled dates (Table $4 \mathrm{a}$ and $\mathrm{b}$ ) suggest a beginning phase of production represented in this location of the first half of the fourth century $\mathrm{BC}$ and an end date towards the end of the first century BC. Considering the dates obtained from MIS 2 and 3, and that MIS1/2 lies stratigraphically downhill from these two slag mounds, dates situated towards the later phases of these slag mounds are unsurprising. It should be noted that no excavations have yet taken place at MIS1 and so the nature and chronological positioning of this supposed slag mound is unclear.

\section{MIS6}

\section{Overview}

MIS6 is $20 \mathrm{~m}$ in N-S diameter and at least c. $2.7 \mathrm{~m}$ high. Four trenches were excavated in this mound from which the samples presented here were taken. The most significant of the original trenches was MIS6-1-14, a $10 \times 8 \mathrm{~m}$ trench which revealed the only furnace workshop found so far during this 
research (details of this workshop will be published in the future). The trench was excavated to just over $1 \mathrm{~m}$ deep along its western edge. The metallurgical deposits were present up to $40 \mathrm{~cm}$ thick in the upper part of the west section and $90 \mathrm{~cm}$ thick towards the middle of the section. Trench MIS6-2-14 was positioned at the north western corner of the slag mound and revealed very mixed metallurgical deposits present in the top c. $1 \mathrm{~m}$, including significant quantities of ceramics. Trench MIS63-14 and 6-4-14 ran parallel to each other starting at the highest point of the mound and running to the north. These trenches revealed earlier architecture underlying the metallurgical deposits, with mud brick walls found at a depth of c. $1 \mathrm{~m}$. Therefore although the mound appears c. $2.7 \mathrm{~m}$ high from current ground level, the metallurgy is (at least where excavation trenches have been positioned) only $\mathrm{c}$. $90 \mathrm{~cm}-1 \mathrm{~m}$ deep at the very top of the mound (see Humphris and Carey 2016 for a further discussion of the metallurgical deposits of MIS6).

\section{Stratigraphy and Mound Formation}

Due to the positioning of this slag mound on top of earlier architecture, the stratigraphy of the metallurgical deposits is particularly complex at MIS6. At the highest point of the mound and towards the eastern end, the slag deposits are present as well stratified metallurgical dumping contexts as seen in other slag mounds described in this paper. However, towards the western and southern parts of the mound, the location of older walls and rooms seems to have influenced the slag deposition. It would appear the furnace workshop was constructed within and around the remains of an earlier building. While the mound raises c. $2.7 \mathrm{~m}$ from ground level today, in ancient times it was probably not much higher than the c. $90 \mathrm{~cm}-1 \mathrm{~m}$ of metallurgical deposits found at the top of the mound. Subsequent erosion of the surrounding levels not protected by the slag has presumably created the more pronounced mound visible today, with slag having washed down towards the edges of the new mound slopes (a phenomenon also evident at Hamadab — see below).

\section{Chronology}

The charcoal dated from MIS6 suggests a maximum span of c. 360 years of metallurgical deposit formation, lasting from the end of the second to the first half of the sixth century AD. Trench 2, containing the lowest deposits situated downhill from the steepest part of the mound, yielded the earliest date. Conversely, trench 3, situated at the highest point of the mound, yielded the latest dates.

Four excavated contexts provide an indication of the final working phase of the workshop (assuming the workshop was cleaned regularly). Charcoal samples were dated from the furnace, the smithing hearth, the working pit and a dump of material associated with the smithing hearth. In addition, charcoal was dated from a hearth underlying the working floor of the workshop, the first (preserved) floor and a post use deposit overlying all of the contexts. The furnace workshop is positioned chronologically towards the end period of the formation of the mound, mainly in the first half of the fifth century $\mathrm{AD}$ (Table $5 \mathrm{a}$ and $\mathrm{b}$, and Appendix A 05). A number of reasons can be postulated for the late dates obtained from the furnace workshop in relation to the rest of the slag mound (Table $6 a$ and $b$ and Appendix A 06) and these will be discussed in future publications. It should be noted that no furnace structures were found below the furnace at MIS6, unlike the situation encountered on the north mound by Shinnie and Tylecote (Shinnie and Anderson 2004, pp. 77-78).

\section{HMD}

\section{Overview}

Situated c. $3 \mathrm{~km}$ to the south of Meroe, the Meroitic town of Hamadab is a largely sub-surface archaeological site, aside from a number of slag mounds which were investigated as part of this research. Excavations were carried out at Hamadab as part of a collaboration between UCL Qatar and the Hamadab Archaeological Project directed by Dr. Pawel Wolf (German Archaeological Institute). Slag mound 100-200 lies to the east of the town wall and is $\mathrm{c}$. $18 \mathrm{~m} \mathrm{~N}-\mathrm{S}$, with a depression in its centre suggesting that originally this had been two separate mounds situated closely together. The highest point of the mound is less than $1 \mathrm{~m}$ above current ground level. Three trenches were excavated in this mound: HMD 2012-10 was positioned in the middle of the mound and was a $5 \times 5 \mathrm{~m}$ trench excavated to a maximum depth of $1.60 \mathrm{~m}$. The metallurgical layers reached a depth of c. $70 \mathrm{~cm}$ from the top of the mound and were separated by intermittent layers of sand build-up. In the southern end of mound, trenches 2012-08 and -09 were positioned in one row running to the west and east separated by a $50 \mathrm{~cm}$ baulk at the highest point of the mound. Excavated to a maximum depth of c. $1 \mathrm{~m}$, metallurgical deposits dominated the upper $60 \mathrm{~cm}$ at the highest point of the trenches. Approximately $20 \mathrm{~m}$ to the 
Table $7 \mathbf{a}$ and $\mathbf{b}$ Unmodelled and modelled earliest and latest radiocarbon dates from the slag mounds at Hamadab

\begin{tabular}{|c|c|c|c|c|c|c|c|c|c|c|c|c|c|c|}
\hline \multirow{3}{*}{\begin{tabular}{|c|} 
T 07a \\
$\begin{array}{c}\text { Fieldwork Sample } \\
\text { Details }\end{array}$ \\
$\begin{array}{c}\text { Trench/Section/Context } \\
\text { in stratigraphic top-down } \\
\text { sequence per trench }\end{array}$ \\
\end{tabular}} & \multicolumn{12}{|c|}{${ }^{14}$ C Dates Hamadab: HMD 100/200/300/800 - modelled Dates } & & \\
\hline & \multicolumn{2}{|c|}{$\begin{array}{l}\text { Laboratory } \\
\text { Data }\end{array}$} & \multicolumn{6}{|c|}{ Unmodelled Calibration calAD } & \multicolumn{6}{|c|}{$\begin{array}{l}\text { Bayesian Modelling (per trench) calAD } \\
\text { (1) Sequence } \\
\text { (2) Phase (two dates from same context) }\end{array}$} \\
\hline & AA \# & $\begin{array}{c}{ }^{14} \mathrm{C} \text { Age } \\
\text { BP } \\
\pm 1 \sigma \\
\end{array}$ & \begin{tabular}{|r}
$95.4 \%$ \\
ranges \\
\end{tabular} & from & to & $\mu$ & $\sigma$ & $\mathbf{m}$ & $\begin{array}{r}95.4 \% \\
\text { ranges }\end{array}$ & from & to & $\mu$ & $\sigma$ & $\mathrm{m}$ \\
\hline HMD 100/2012-10/N/12529 & AA100359 & $\begin{array}{c}1,609 \\
\pm 50 \\
\end{array}$ & 95.4 & 338 & 563 & 457 & \pm 61 & 460 & (1) 95.4 & 400 & 560 & 488 & \pm 43 & 496 \\
\hline HMD 100/2012-10/W/12530 & AA100358 & $\begin{array}{c}1,603 \\
\pm 38 \\
\end{array}$ & 95.4 & 383 & 550 & 467 & \pm 49 & 468 & (1) 95.4 & 384 & 535 & 451 & \pm 44 & 447 \\
\hline HMD 200/2012-08/N/12501 & AA100353 & $\begin{array}{c}1,578 \\
\pm 38\end{array}$ & 95.4 & 401 & 562 & 482 & \pm 44 & 482 & (1) 95.4 & 400 & 552 & 475 & \pm 44 & 472 \\
\hline HMD 200/2012-08/N/12502 & AA100352 & $\begin{array}{c}1,648 \\
\pm 38\end{array}$ & $\begin{array}{r}2.6 \\
78.4 \\
14.5 \\
\end{array}$ & $\begin{array}{l}262 \\
327 \\
485\end{array}$ & $\begin{array}{l}278 \\
475 \\
536\end{array}$ & 405 & \pm 59 & 400 & \begin{tabular}{rl|} 
(1) & 84.6 \\
& 10.8
\end{tabular} & $\begin{array}{l}331 \\
484\end{array}$ & $\begin{array}{l}475 \\
531\end{array}$ & 408 & \pm 49 & 404 \\
\hline HMD 200/2012-09/N/12519 & AA100351 & $\begin{array}{c}1,637 \\
\pm 38\end{array}$ & 95.4 & 335 & 537 & 424 & \pm 59 & 413 & (1) 95.4 & 431 & 543 & 497 & \pm 29 & 502 \\
\hline HMD 200/2012-09/N/12520 & AA100361 & $\begin{array}{c}1,530 \\
\pm 38\end{array}$ & 95.4 & 425 & 605 & 516 & \pm 54 & 523 & (1) 95.4 & 418 & 528 & 468 & \pm 29 & 467 \\
\hline HMD 300/2012-12/W/12542 & AA100357 & $\begin{array}{c}1,648 \\
\pm 37\end{array}$ & \begin{tabular}{r|r}
2.4 \\
79.1 \\
13.9
\end{tabular} & $\begin{array}{l}262 \\
327 \\
485\end{array}$ & $\begin{array}{l}278 \\
475 \\
535\end{array}$ & 405 & \pm 58 & 400 & \begin{tabular}{rr|}
$(2)$ & 1.6 \\
& 86.1 \\
& 1.8 \\
& 5.9 \\
\end{tabular} & $\begin{array}{l}263 \\
326 \\
449 \\
488 \\
\end{array}$ & $\begin{array}{l}277 \\
439 \\
469 \\
532 \\
\end{array}$ & 393 & \pm 46 & 393 \\
\hline HMD 300/2012-12/S/ 12542 & AA100354 & $\begin{array}{c}1,676 \\
\pm 38 \\
\end{array}$ & $\begin{array}{r}94.6 \\
0.8 \\
\end{array}$ & $\begin{array}{l}251 \\
497 \\
\end{array}$ & $\begin{array}{l}429 \\
506 \\
\end{array}$ & 362 & \pm 52 & 367 & \begin{tabular}{|lr}
2 & 7.2 \\
& 88.2 \\
\end{tabular} & $\begin{array}{l}256 \\
312 \\
\end{array}$ & $\begin{array}{l}304 \\
430 \\
\end{array}$ & 372 & \pm 43 & 376 \\
\hline HMD 800/2012-13/W/12557 & AA100360 & $\begin{array}{c}1,584 \\
\pm 38 \\
\end{array}$ & 95.4 & 397 & 558 & 479 & \pm 45 & 480 & (1) 95.4 & 416 & 553 & 491 & \pm 39 & 499 \\
\hline HMD 800/2012-13/W/12561 & AA100362 & $\begin{array}{c}1,598 \\
\pm 37 \\
\end{array}$ & 95.4 & 389 & 548 & 471 & \pm 46 & 473 & (1) 95.4 & 406 & 535 & 468 & \pm 39 & 467 \\
\hline HMD 800/2012-13/S/12560 & AA100350 & $\begin{array}{c}1,614 \\
\pm 37\end{array}$ & $\begin{array}{r}1.8 \\
93.6\end{array}$ & $\begin{array}{l}353 \\
380\end{array}$ & $\begin{array}{l}366 \\
543\end{array}$ & 457 & \pm 52 & 457 & (1) 95.4 & 384 & 530 & 444 & \pm 43 & 432 \\
\hline
\end{tabular}

south of mound 100-200 lies mound 300, which is similar in volume and height. One trench, 2012-12, was excavated here, running to the north from the highest point of the mound. This trench was excavated to a depth of $1.40 \mathrm{~m}$. The metallurgy reached a depth of $60 \mathrm{~cm}$ from the top of the mound, and overlay c. $20 \mathrm{~cm}$ of sand before a mud brick wall was reached in the southern most section. Approximately $140 \mathrm{~m}$ to the south-west of mound 300 is mound 800 , which is almost round in shape with a diameter of c. $20 \mathrm{~m}$ and a height of c. $2 \mathrm{~m}$. Trench 2012-13 was excavated running east from the middle of this mound. The trench was just over $1 \mathrm{~m}$ deep at the centre of the mound, with metallurgical deposits comprising only the top c. $40 \mathrm{~cm}$.

\section{Stratigraphy and Mound Formation}

The slag mounds at Hamadab are relatively thin metallurgical layers overlying sand accumulation and earlier architecture. The slag sections in trench 10 of mound 100-200 indicated that two original mounds were deposited at this location. Trenches 8 and 9 display typical, well stratified metallurgical deposits while those in trench 10 were slightly more mixed. Due to the narrow nature of the trench in mound 300, it was difficult to discern exactly how this mound may have formed. The layers in mound 800 appeared relatively horizontal and so it is impossible to say where an original core of this shallow mound may have been.

\section{Chronology}

Aside from mound 800, a number of inverted dates from the Hamadab trenches could highlight the problem of old wood or perhaps slag mixing (Appendix A 07). Based on the modelled dates (Table 7a and b), a chronology of iron production at Hamadab can be proposed that extends from the middle of the third century to the mid-sixth century AD. Mound 300 provides the potentially earliest dates for the deposition of iron production waste at the site, while iron production could have started later in furnaces responsible for creating mounds 100 and 800 . Interestingly, pottery and redbrick structural remains indicate Medieval settlement activity just to the south of the Meroitic site of Hamadab (Wolf pers. comm.). Iron production during the later periods could relate to this settlement. Additional iron production remains to the west of the site of Hamadab are yet to be explored. 
Table 7 (continued)

Table 07b - HMD 100/2012 - 10 Sequence
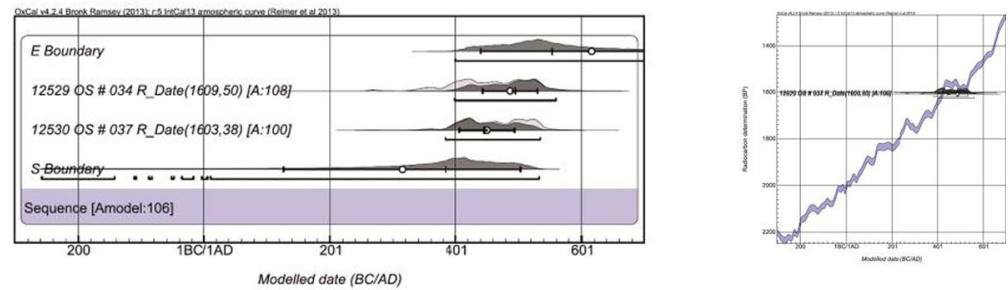

Table 07b - HMD 200/2012 - 08

Sequence
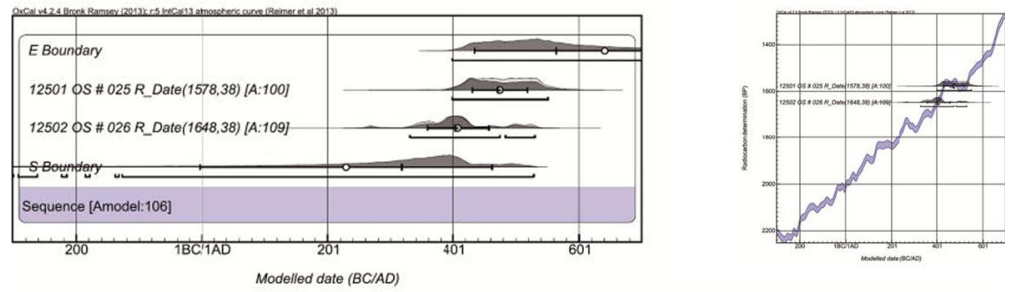

Table 07b - HMD 200/2012 - 09

Sequence
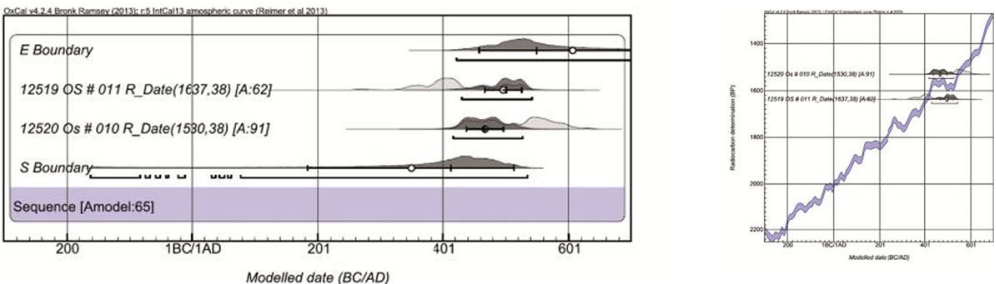

Table 07b - HMD 300/2012 - 12

Phase (2 dates from same context)
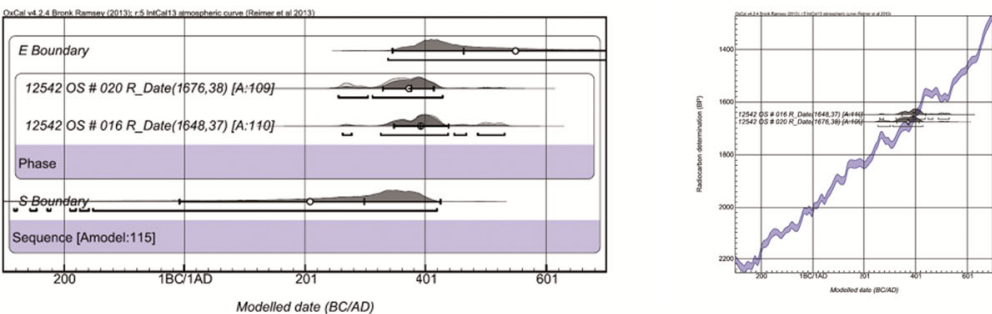

Table 07b - HMD 800/2012 - 13

Sequence
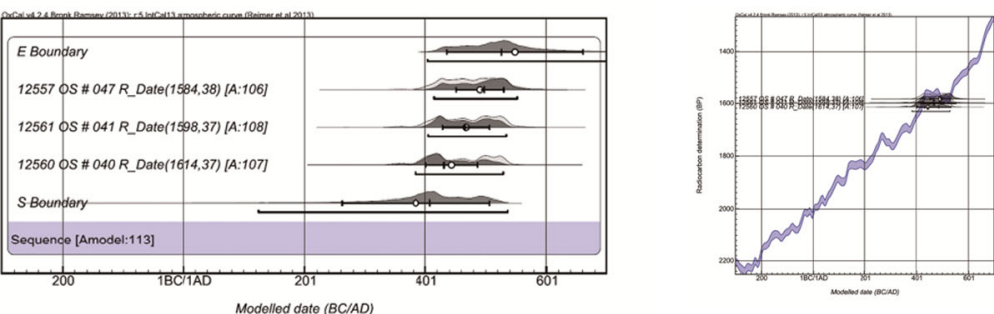
Luminescence Dating

During the excavation of the trenches at MIS4 and Hamadab, a luminescence-dating strategy was implemented to enable the production of a more precise chronology. Samples and their associated dosimeters (which were positioned within the slag mounds in direct relationship with the dated samples for a one-year period to provide dosimetry for calibration) were analysed at the Luminescence Dating Laboratory, University of Washington. The OSL and TL results will be published in more detail in the future. In general and despite various problems, these dates support the dating span at MIS4. They also support the later end of the radiocarbon sequences produced during the calibration and modelling of the Hamadab dates, suggesting that iron production could have continued into the Medieval period of occupation at this site. A more conservative suggestion, considering the radiocarbon dating, would be to date the Hamadab samples to a Transitional period between the post-Meroitic period and the Medieval period, which would perhaps make more sense due to the apparent decline in general activity in the area from the Medieval period.

\section{Discussion}

Considering the Validity of the Early Dates

Using stratigraphy as the relative chronological framework for the interpretation of the radiocarbon chronology presented above, resulted in dates that appeared too old being rejected as potential outliers and therefore excluded from subsequent modelling. However, due to the potential for mixed slag-mound formation as described above, dates which are too old in relation to the stratigraphic sequence may still be reliable indicators of periods of time during which iron production was carried out at Meroe; such dates may simply derive from a different chronological period. Thus, older (inverse) dates within a younger sequence could still correctly date iron production, especially as the contexts within the MIS4 slag mound were not mixed with non-metallurgical material and so do appear to come from iron production phases. Understanding where an outlier date could be the result of the old wood effect, and where such a date is simply the result of asynchronous slag mound deposition, is difficult. Is it really more plausible to suppose, for example, that the date from context $4052(2590 \pm 42 \mathrm{BP})$ in trench MIS4-2-13 is an old wood date, when this sample is c. 300 years earlier compared to the dates deriving from other contexts in the same trench (see Appendix A 01). Alternatively, could this sample simply have been deposited out of chronological sequence, and correctly reflect a time of iron production? The essential question in this respect is what exactly we aim to date. It is not only the formation history of the slag mounds or the depositional sequence of single metallurgical layers, for which ${ }^{14} \mathrm{C}$ dating provides only a terminus post quem, but the dating of iron production itself that we are concerned with. In our attempt to remain conservative in handling the radiocarbon data, we have removed possible outliers until further investigations can be carried out. However, there is a significant possibility (especially as all charcoal samples were checked for signs of possible old wood effect before being sent for dating), that the maximum earliest and latest dates listed in this paper do reflect the realistic maximum time periods of iron production at Meroe, according to the state of research to date. This means that there could have been iron production at Meroe at the beginning of the Kingdom of Kush (or earlier), lasting until a time period well after the decline of the Kingdom.

Chronological Relationships Between the Slag Mounds

The absolute radiocarbon chronology of iron production at Meroe and Hamadab described here is based on the investigation of nine slag mounds in three spatially separated areas: MIS1/2, 2, 3 and 4 to the east of the Royal City, MIS6 with its furnace workshop on the south mound of the City, and the slag mounds at Hamadab. According to the radiocarbon dates presented here, the investigated slag mounds originate from two distinct chronological periods of iron production (Fig. 4). The earlier period is represented by the eastern group of mounds at Meroe; the later period is reflected by MIS6 and by the slag mounds at Hamadab. The extensive potential time span of iron 


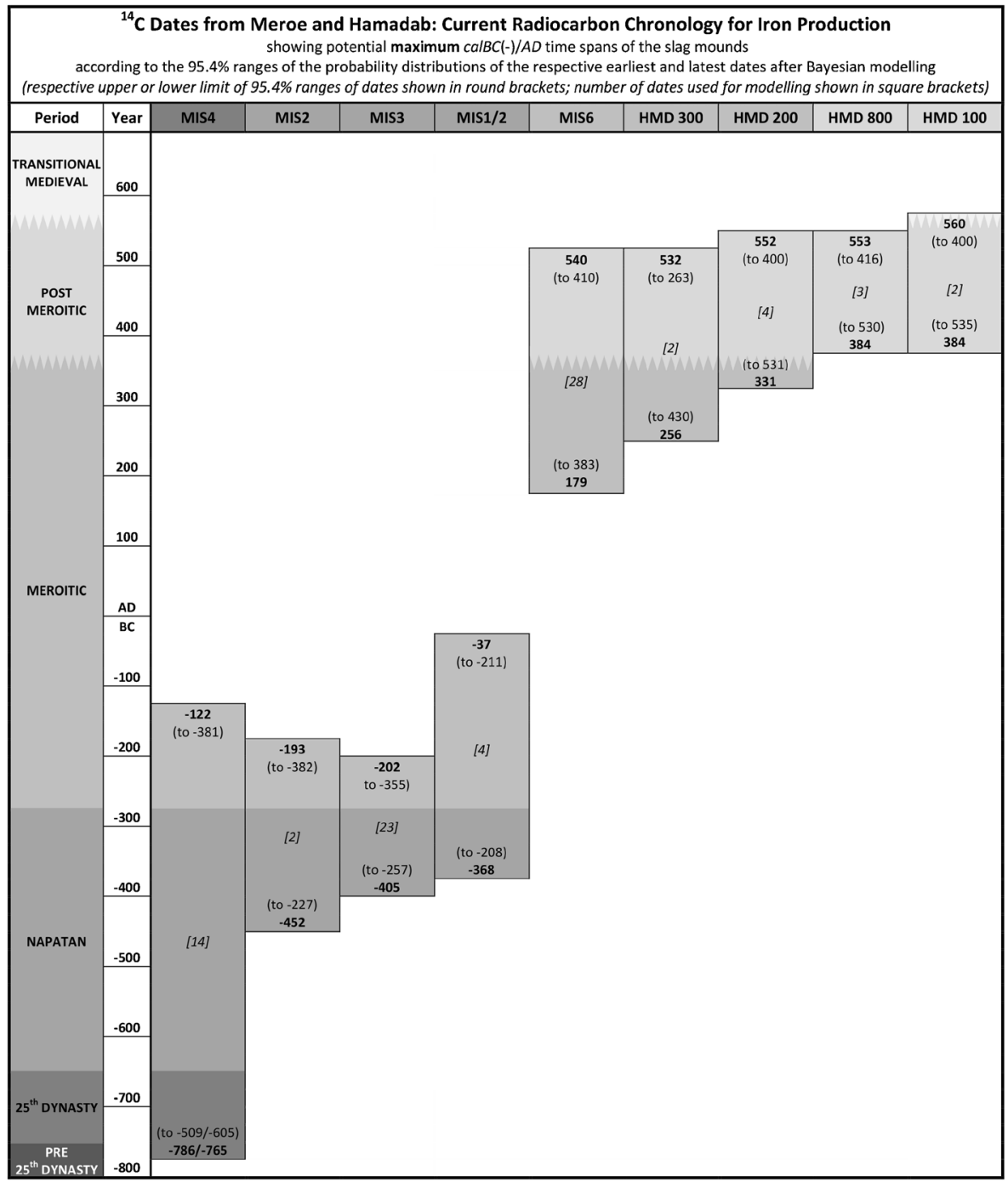

Fig. 4 Current radiocarbon chronology for maximum time range of iron production at Meroe and Hamadab. The modelled potential maximum $c a l B C / A D$ start and end dates of the slag mounds are

production covered by each of the mounds reflects the maximum span of this new chronological framework according to the $95.4 \%$ ranges of the probability distributions of the respective earliest and latest dates. Future work will certainly produce a higher resolution chronological understanding, probably narrowing the date ranges for some of the mounds and perhaps shifting the dates for the inception and ending of iron production in the area. The wide overlaps in the deposition chronology of different mounds indicated by the currently available dates may become smaller in future. Hence the gap between the two production periods represented here could extend or diminish. In illustrated according to the $95.4 \%$ ranges of the probability distributions of the respective earliest and latest date

general, the iron production potentially spanned well over 1000 years, starting possibly as early as the 25 th Dynasty in the mid-eighth century, certainly flourishing from the sixth century $\mathrm{BC}$, and ending during the early Medieval (or transitional) period at Meroe and Hamadab, where it started much later in the mid-third century AD.

In the eastern metallurgical deposition area (which we assume to be close to the original production area), there is an apparent succession in the beginning of the formation of the mounds, starting with MIS4 and followed by MIS2, 3 and $1 / 2$. The creation periods of all mounds situated in this area overlap, 
seemingly for considerable time. More precisely, MIS4 extends far over the entire time spans of MIS 2 and 3. Only the area of MIS1/2, starting later than the other mounds in the fourth century BC, potentially reaches almost to the turn of the millennium. General scale of production indicated by the extent of the mounds in the east may represent a particularly intensive production period starting at least by the middle of the Napatan period, extending through the early Meroitic period, possibly equivalent to an increasing number of furnaces in operation. This is particularly interesting because this period relates to a time when increased economic activity in the Meroe region is noted (see below). However, using visible quantities of metallurgical debris as an indication of scale of production is problematic before information such as the type of ore and efficiency of production, as well as quantities of slag produced per smelt, is understood in relation to changes over time. Archaeometallurgical research is ongoing to understand these questions. Nevertheless, the apparently early sub-surface slag deposits revealed by Shinnie's excavations to the east and north-east of the Royal City (Shinnie and Anderson 2004, pp. 8, 73-74; see Carey et al., Investigating the ironworking remains of the Kingdom of Kush, Meroe, under review for information relating this current research to the results obtained by Shinnie) contribute to an impression of high production intensity of iron during the early period of Kush. Additionally, early production evidence found by Shinnie is located on the north mound, suggesting it was not the case that early iron production only took place in the eastern locale of the city.

Metallurgical debris was dumped at MIS4 potentially during a period of 600 years and probably longer. MIS3 is the second largest mound in the east, with a volume of approximately a quarter of MIS4, which is well reflected in the much shorter deposition sequence of c. 200 years. The smaller mound MIS2 was deposited over c. 260 years, although this is based on only two dates coming from one trench. The MIS1/2 area covers 330 years based on four dates from two trenches.

Regarding MIS2 and 3, the chronology presented here provides a terminus post quem for the erection of both the Kiosk and the Apedemak temple, which accordingly could not have been constructed until at least the second century BC. Previous dating of the Apedemak
Temple, based largely on various inscriptions found during the excavations of the site by Garstang, provide a variety of chronological suggestions for this event. Wainwright $(1945$, p. 23) suggested the temple was founded by the middle of the first century BC. Žabkar (1975, p. 11) dates the temple's use to a slightly earlier period based on a plaque found by Garstang depicting Apedemak with a king, and the name Tanyidamani written in Meroitic cursive text. Of course, this plaque may have been placed in the temple later than its construction and may not be a reliable source of relative dating. However, according to Török (2015, p. 107; see also Török 1997b, p. 447), Tanyidamani ruled in the late second-early first century BC. If the plaque is contemporary to the construction of the building, it would therefore appear that the Apedemak Temple was constructed around $100 \mathrm{BC}$. Since dumping of metallurgical debris at MIS4 and MIS1/2 could have been continued until the end of the second or end of the first century BC respectively, it could be suggested that iron production, or at least the dumping of metallurgical deposits, ceased within this eastern area because of the construction of the religious buildings, reflecting a change in the use of this area of Meroe.

Based on the dates derived from MIS6, there is an apparent minimum potential hiatus in time between iron production to the east of the Royal City and that being carried out here, of more than 200 years. The most probable explanation for this interruption is the current state of research, which has not yet investigated all visible slag mounds (notably those situated in the north mound of the city, and slag mounds situated to the north and east of the north mound; cf. Fig. 1) and the potential sub-surface slag deposits.

MIS6, which began to be accumulated in the Late Meroitic period at the end of the second century AD, is the earliest mound of the later chronological group of metallurgical deposits identified so far, which includes those at Hamadab. The sequence of the deposits at Hamadab begins with HMD 300, followed by HMD 200 and then contemporarily HMD 100 and 800. HMD 300 and 200 begin in Late Meroitic times but at different points, whereas the beginning of the HMD 800 and 100 deposits date to the post-Meroitic period in the late fourth century AD. All deposits of this group end more or less in the mid-sixth century AD between 532 and 560 calAD, thus at the end of the post-Meroitic period, or during the period in which a transition occurs to the Medieval period. Hamadab appears to increase the scale 
of metallurgical production from the late to the post Meroitic period, with the earlier slag mounds still in use simultaneously as the later deposits accumulated. All of these later deposits again run contemporaneously for significant time periods, and MIS6 almost overlaps the whole time span of the Hamadab slag deposits. The furnaces excavated by Shinnie to the north-east of the Royal City (dated to AD 300-500, Shinnie and Kense 1982, p. 24) also belong to this later group. Such spatial organisation of contemporary production workshops prompts significant questions over control and organisation of iron production and how this changed, or remained constant over time. Iron production was taking place to the east and north of the City during the earlier phase of production (Shinnie and Anderson 2004, p. 73), and to the south and north of the Royal City and at Hamadab during the later phase. Why production took place at different locations during the same period will become evident as laboratory analysis of samples develops, and as further details about difference and similarities between these production locations are revealed. Concepts of family smelting groups, production workshops responsible for supplying different types of objects or furnaces under the control of different officials are just some of the possible explanations.

\section{Contextualising the Chronology}

The study of craft production, as a material manifestation of the position and role of the artisan and the respective technology within the broader social, economic, political, religious and environmental contexts, is fundamental to the understanding of life in the past (Costin 2005, p. 1037; Martinón-Torres et al. 2014; Pfaffenberger 1992). How, why and by whom are questions that have the potential to reveal aspects of social organisation that will be of major significance in understanding the different time periods of iron production explored in this paper, contributing to the growing understandings of life during the Kingdom of Kush. Revealing and inserting into this new chronological framework levels of standardisation and variation identified within the archaeometallurgical remains, as well as the finer nuances of production accessible through high resolution laboratory analysis, will be instrumental in providing an insight into the socio-political and economic aspects of ancient life around Meroe.
The periodisation of the Kingdom of Kush, and understandings of its internal politics, remains problematic, for example the relevance of the shift in Royal burials from Napata to Meroe (Edwards 2004, p. 112; Welsby 1996, p. 8). The current state of research and the confusing radiocarbon dates and stratigraphy of the earliest settlement strata from Meroe makes the early history of the site relatively difficult to interpret (Török 1997a, pp. 15-20). Based on the assumption that the "transition in brick size" was "roughly simultaneous at Sanam and Meroe," the comparison of mudbrick sizes from early occupation levels at Meroe with the brick sizes in the foundation of the Sanam temple, "dated reasonably reliably to around 680 B.C.," would place the beginning of settlement at Meroe to the eighthseventh century BC (Bradley 1984, p. 198). The earliest burials at Meroe (Begrawiya South and West) date to a similar period (Dunham 1963), and a charcoal sample taken from the wall foundation of building SM100 on the south mound of the Royal City also supported the idea of the beginnings of settlement at Meroe at least during the 25th Dynasty period and perhaps before (Grzymski 2005, p. 49, 2008). In his recent considerations of the origins of Meroe, Pope (2014, pp. 5-34) concludes that the settlement was certainly in existence during the 25th Dynasty and possibly before, and perhaps was an early centre of power (although relationships between Meroe and Napata are more complex than previously thought). According to Edwards (2004, p. 112), Meroe was a "major political centre" before the appearance of the Begrawiya royal burials and may have been the main royal residence from the sixth century BC. Consequently, it is perhaps unsurprising that people were producing iron at Meroe at this time, in a location where all resources necessary for iron production were available. A relationship between the beginnings of the settlement of Meroe and the beginnings of iron production at the site can be considered now that it is known that the two are perhaps contemporary. Was the appearance of one a stimulus for the development of the other? We believe this to be the case, and continuing excavations and analysis, both archaeological and archaeometallurgical, will assist in understanding this further in due course.

\section{Conflict as a Stimulus for Increased Iron Production?}

In his most recent exploration of Kushite history, Török (2015, p.12) proposes 12 periods from the tenth century 
$\mathrm{BC}$ and the chiefdom of El Kurru, to the end of the Kingdom during the fourth century AD (details provided below concerning the periods of Kushite history are taken from Török 2015). Situating the radiocarbon chronology within these periods provides insight into potential stimuli for iron production, and indications of why throughout time production may have increased and decreased in scale.

The emergence of the Kingdom can be traced back to the beginnings of the first millennium BC and the Egyptian retreat from Nubia. This pre-25th Dynasty period sees the appearance of a series of chiefs buried in the earliest tombs at El Kurru. During this time, it can be hypothesised that a powerful family or a cluster of families led by charismatic, authoritative and influential "chiefs" took advantage of the power vacuum to the north and became rulers over a significant territory and population. Potentially, iron production may have begun at Meroe during this period. In other locations in Africa, iron production has been dated to this period, for example in Nigeria (Eze-Uzomaka 2013) and Rwanda and Burundi (Van Grunderbeek 1992), although most welldated production locations in western, central and eastern Africa are dated to the period from c. 800-400 BC (Killick 2009; see Clist 2013 for a summary and critique of early dates for iron production). Török suggests that this El Kurru chiefdom precedes the kingship of Kush, although detailed understandings of the complex sociopolitical organisations and intricate power relations (see McIntosh 1999) which provided the mechanisms for social change (Maisels 2012, pp. 349-354; see also Robertshaw 1999 for a consideration of state formation in relation to "chiefdoms") are lacking (such understandings are also lacking for much of the period of the Kingdom of Kush: Pope 2014, pp. 2-3).

From the time of the Double Kingdom of Kush, (beginning in the first half of the 8th century BC), when Kushite Kings ruled Egypt as the 25th Dynasty, we now potentially have an absolute chronology for iron production at Meroe. However, Meroe at least at the beginning of this time was possibly an independent region (or chiefdom), which was probably "gradually annexed" by Kush (Pope 2014, pp. 5-33). If the Meroe region can be viewed as an independent chiefdom (or series of chiefdoms) during this time, its ability to supply iron products may have both secured the political dominance of those controlling the resources and products of the iron production practices around Meroe, and perhaps created trade to the north of this valuable product which helped maintain friendly relations with powerful neighbours, and ultimately stimulated this gradual annexation. Perhaps familial ties (it is known that family members of the 25th Dynasty and before intermarried with those from the Meroe region), or simply preoccupation with the north, prevented aggressive annexation by the rulers of the Dynasty (which lasted until around the middle of the 7th century BC). It could also be that those in the north recognised Meroe's ability to produce large quantities of iron as the application of a sophisticated technological skill that they themselves did not possess (necessitating good relations with Meroe), and as a means of Meroe arming itself with superior weapons, should such an annexation turn violent.

It could be suggested that internal ambition for territorial dominance, and external pressures from powerful neighbours, provided a stimulus for increased production of iron weaponry during these early periods, resulting in the apparent large-scale production possibly indicated by the scale of the early iron production remains (although as mentioned above, we rely here on a simplistic model that greater quantities of slag equate to greater levels of iron production, while laboratory analyses allowing a more sophisticated interpretation of scale of metallurgical waste at Meroe are pending). Lower Nubia came under Egyptian control by the early sixth century BC. During the later sixth and fifth century $\mathrm{BC}$, the Persian conquering of Egypt, followed by antiPersian uprisings, gave way to an expansion of Kush back into Lower Nubia. Subsequent, recurrent revolts against the Kushites into the fourth century BC could have continued to create increased demand of iron weapons. Such an increased demand during these times could be reflected by the beginning of the creation of slag mounds MIS 2 and 3, in addition to the workshops already creating MIS4. It was also documented that Kush was in conflict with southern nomads, particularly during the first half of the fourth century BC under the rule of Harsiyotef, who again assumed control over the whole of Lower Nubia. Rebellions continued in Lower Nubia throughout later part of the fourth century BC, where following Alexander's conquest, increased rebellions began.

From the third century BC, "one of the golden ages of Kushite history" (Török 2015, p. 69) began at Meroe. Increased building activities are evident at Meroe and Musawwarat. Such activities 
would have presumably required iron tools for quarrying stone and for architectural implements. The reoccupation of Lower Nubia and subsequent revolt in the first quarter of the second century $\mathrm{BC}$ indicate a potential continuous demand for iron weapons, supporting the notion that the apparent hiatus in production remains indicated by this chronology probably reflects current state of research. Of course, it should be noted that weapons made of material other that iron could have formed a part of the Kingdom's weaponry. It is perhaps interesting that local princes were particularly prominent at Meroe around this time, and are buried in Begrawiya West cemetery. Could these local "princes" have been in control of some of the iron production at Meroe, and perhaps be the reason why different iron production locations existed at the same time? It could also be interesting that external politics appears to be quieter from the mid-end of the second century to the mid-late first century $\mathrm{BC}$, perhaps resulting in a decreased demand for iron, possibly reflected in the decrease in production indicated by the cessation of the creation of MIS 2, 3 and 4 .

In $25 \mathrm{BC}$, the Romans fought and defeated the Kushites in Lower Nubia and subsequently launched an unsuccessful campaign to conquer the whole of Kush, following which peaceful relationships with Rome were negotiated. Again, building works flourished, notably in the first century AD under the rule of Natakamani and Amanitore and their successors, during what was one of Kush's most prosperous (and peaceful?) periods. Lack of data, as noted above, makes estimating iron output during this time very difficult, but there could be a decrease in production at this time (most of slag mounds visible on the north mound of Meroe are small in scale). Investigating the ironworking remains of the Kingdom of Kush, Meroe, under review). By the end of the third century AD, Kush had reoccupied Lower Nubia, ruling through a system of governors and local elites who were seemingly becoming more powerful, as demonstrated by statutory and burials of non-royals appearing the in the early centuries AD.

During the fourth century $\mathrm{AD}$, local princes were able to ascend to the throne, and the royal burials at Begrawiya North became smaller, indicating an evolution in power structures and social organisation. This apparently corresponds to a "decline in urban life ... poor rural-type houses ... Squatter occupation and poor burials" (Török 2015, p. 97). Nevertheless, at least at Hamadab, this period sees the development of a previously unseen iron production practice at this site, starting at the time when probable pressure from Aksum in the east, and raiding nomads from the west, was increasing (although significant subsurface (earlier) slag deposits may exist at Hamadab that have not yet been found). This evolving political environment perhaps provided the stimulus for the production of quantities of iron for weapons, and the occurrence of iron weaponry in burial contexts does appear to increase during the post-Meroitic period (Abdelrahman 2011). At Meroe, at least at MIS6 and partly from the work of Shinnie and Tylecote, we can see from the dates provided here that a significant level of iron production, requiring organisation of labour, access to resources, and displaying evidence of continuations of some fundamental aspects of technological practice such as charcoal selection, was also taking place at this time, either to supply a local or external market. Such archaeometallurgical data add complexity to understandings of the concept of diminishing central power and control. For example, the concept of rising powerful local men or princes at this time, in relation to a weakening central system of control, could help explain why at Hamadab iron production begins to be practiced seemingly for the first time and with apparently more freedom for smelters to apply their own methods to their craft. New polities began to emerge during the period from the fourth to sixth centuries $\mathrm{AD}$ throughout the wider region, and perhaps the iron production at Meroe and Hamadab at this time was to supply these new markets, or to provide weapons for the protection of the Meroe region from these growing powers.

\section{Further Stimuli for Increased Iron Production}

If consumer demands were at an increased level during the early periods, one should consider what objects were being made aside from weapons which could have provided stimulus for large-scale iron production. It is interesting to note that agriculture was flourishing during the Napatan and into Meroitic times, with barley and wheat grown at least in the north and used in part for the production of bread. Cotton and domesticated sorghum is known from later times but may well have been grown during the Napatan/early Meroitic times (Edwards 2004, p. 138; Welsby 1996, pp. 158-161). Thus iron agricultural tools were presumably used during this 
agricultural blossoming, especially considering that "Most of the population of Kush, particularly in the north, was engaged in farming activities" (Welsby 1996, p. 151). Discussions with modern-day blacksmiths in the area confirm the continual market for new agricultural tools in addition to the high demand for repairing existing tools, in an agricultural context that bears some similarities to that of the past (many people involved in high-intensity crop harvesting and planting at certain times of the year, using quite small, and relatively quickly blunted iron tools). Increases in building activities throughout the kingdom, mentioned above, necessitating not only major stone quarrying but also functional objects to create the architecture (hammers, chisels, picks, etc.) would also have driven producer-consumer relations.

The construction of hafirs (Arabic from hafara-to dig; plural: hafair), artificial water reservoirs dug into the ground, serving as catchment basins to collect the seasonal rainwater run-off from the wadis (seasonal streams; Arabic plural: wadein), took place at a considerable number of sites within the Kingdom of Kush (see M. Hinkel 2015). At least the largest hafirs, such as the Great Hafir at Musawwarat es-Sufra, were probably related to agriculture (also requiring iron tools) and used for "supplementary irrigation" (see Scheibner 2014, pp. 299, 315). Such massive excavation and construction probably required iron tools, in particular where they were cut into the underlying Nubian sandstone, as was the case at Musawwarat (Scheibner 2004, p. 51) or into a calcrete surface as was the case at Meroe. Indeed, impressions of hoe-shaped, potentially iron tools, were revealed in the spoil material within the embankments of the Small Hafir at Musawwarat (Scheibner 2017, pp. 132-133; Fig. 34). This Hafir provided (modelled) radiocarbon dates for construction, presumably requiring a significant workforce using iron tools (who would have made up such a workforce is a particularly interesting question), in the Late Napatan or Early Meriotic period (in the second half of the fourth and at the latest in the third century calBC; see Scheibner 2011, p. 32).

Considering that much of the major building works were by royal commission, and that the state drove the expansion and protection of frontiers and was presumably fundamental in the organisation of at least some economic production such as agriculture (notably to ensure a food supply to the nonfood producing portion of society such as soldiers and administrators: Welsby 1996, p. 138), the motivating factors at play during periods of more intense iron production begin to be revealed. Such details support the concept of a significant internal markets for substantial quantities of iron implements during different phases of the kingdom. Therefore, whether or not iron production was run and controlled by the state at certain times, the state certainly provided increased market demands in relation to broader social, political and economic requirements. Iron production was part of the wider web of socioeconomic, politically driven market forces.

\section{Additional Considerations}

Further questions of significance relate to how the technological knowledge to produce iron arrived at Meroe and when: did this arrive through external contacts (for example through trade contacts and/or the movement of people), or was the technology independently invented at Meroe? A comparison between the technological details of Meroitic iron production and that evident at other sites in Africa and beyond, will allow a greater understanding of this question. This will only be possible once extensive chemical and microscopic analysis of metallurgical samples has been completed, alongside further excavations. Certainly, the later technological approach to iron production in terms of the workshop spaces used (see Shinnie and Kense 1982) seems unlike anything seen elsewhere in Africa; however, preliminary analysis of metallurgical debris indicates some changes in technology over time, and this is currently under investigation.

The early, seemingly very extensive scale of production could lead to a questioning of why so few iron objects are found in early graves of Napata and Meroe (Abdu and Gordon 2004, p. 979; Trigger 1969, pp. 3744). Such questions relate to whether at its beginnings at Meroe, iron was a functional material widely used by much of the population or a luxury good produced on a small scale reserved for the elites, will be understood more as the chronology of the industries is refined and archaeometallurgical analysis continues. However, loss due to corrosion aside, this low number of iron grave goods is perhaps to be expected considering the labour and resources required to create what was a valuable economic resource, and one perfectly suited to reuse and recycling. From the objects found in the early graves, iron weapons seem to dominate the ferrous assemblages (Abdelrahman 2011, p. 397), although this may not be 
representative of the main outputs of the iron industries and possibly relates more to the symbolism of grave goods and their use in the afterlife. Additionally, if iron was being made largely to supply armies, more loss could be expected as the weapons were carried away to battle grounds in the north and perhaps lost during battle.

The question of a possible symbolic positioning of the Apedemak Temple (Haaland and Haaland 2007) and Kiosk on these slag mounds is an ongoing avenue of investigation that will be considered in future publications. There are many instances across the continent whereby iron and power were linked through overt symbolic expressions (see de Maret 1985 for a summary of such examples). The temple situated on MIS3 may have been positioned deliberately to demonstrate a link between the production of iron objects fundamental to the success of the Kingdom (weapons, agricultural tools, quarrying tools and architectural tools, as well as possible exchange items), and Apedemak. The nature of Apedemak, the Meroitic lion-headed war-god, is discussed in detail by Žabkar (1975, p. 17), who notes from inscriptions on the lion temple at Musawwarat es-Sufra that Apedemak is described as "Lion of the south, strong of arm .... one who provides nourishment for all men ... one who sends fourth a flaming breath against his enemies ... who slays the rebels with (his) strength." Further attributes, including iconographic links between Apedemak and the provision of food and water to the Meroites, and Apedemak as a god of fertility, are described by Török (1997b, pp. 502-503). Here, Török presents a further translation within the inscription above which mentions Apedemak as "Great God ... Who makes food for all people," and describes Apedemak as being linked to the water sanctuary at Meroe, as well as being depicted with libation vessels and water containers. Therefore, situating the Apedemak Temple on top of the waste product of iron production may have been a direct emphasis of a link between Apedemak and the power of the kingdom. The recent finds of a possible retaining wall and a building at the foot of the slag mound to the north of the temple would seem to indicate that the landscape immediately surrounding the temple was developed to incorporate technological production remains and the cult of Apedemak within a quite spectacular setting. This will be explored in future publications.

Organisation of production can also be hypothesised. The capture of prisoners as depicted on the reliefs of pyramid chapels for example, lends itself to an idea of slave workforces being tasked with the laborious jobs of mining and quarrying and transporting materials back to the Royal City for iron smelting or construction. A significant problem lies in a lack of understanding of the status of the iron producers at Meroe. Were the iron smelters at times autonomous and at times carefully controlled by the state, and did they make iron for a local market or for wide-scale export trade? Were head smelters in any way powerful or influential? Presumably, these social aspects of production changed over time and were not polarised. Producer-consumer relationships, and the role of the craftspeople in society are fundamental research questions difficult to access through the archaeological record. Related to this is the question of trade. How much Meroitic iron was produced for trade with Egypt, for example? Future mass balance calculations will provide some clues as to how much iron was produced at Meroe during each period, which in turn will feed into such questions as the role of Meroe in regional trade. However, considering the need for iron implements to support and enable Kushite warfare, agriculture, construction, stone quarrying and excavation of hafirs, in addition to other functional and less functional objects (from the iron tools needed to produce more iron objects, to objects used in personal adornment), presumably much of the iron produced at Meroe and Hamadab met the needs to the Kingdom rather than an extensive external trade market.

\section{Conclusion}

Evidence for iron production provides an insight into socio-political and economic structures. As has been described elsewhere (Humphris 2014), to produce iron, a significant workforce is required, with at least some members equipped with sophisticated technological knowledge and skills to perform all stages of the chaine opératoire of iron production to make iron objects and the resulting waste products on which this investigation is based. Wood charcoal was made specifically from Acacia type nilotica (Eichhorn and Humphris, The use of charcoal in Kushite iron production, under review), and significant quantities would have been required for iron smelting and smithing. Iron ore had to be collected and processed, and recent research (Humphris et al., The ancient mines of Meroe, 
under review) demonstrates that at least at certain times this ore was collected from c. $9 \mathrm{~km}$ to the north east of the Royal City where it was excavated from discrete sub-surface lenses present on top of specific hills. Dozens of kilogrammes of iron ore could have been required for each smelting episode. A significant quantity of clay for the production of the furnace and tuyère pipes, as well as for the bellows pots was also needed, and a furnace structure capable of withstanding the extremes of heat and atmospheric conditions needed to be constructed and maintained. The frequency and potential seasonality of iron production throughout the periods denoted here is unknown, as is the number of furnaces in operation at any one time and the quantities of slag produced per smelt. What can be deduced, however, is a certain level of organisation of labour and resource procurement. The laboratory analysis will reveal similarities and differences in ingredients used and in smelting and smithing styles, and how these varied or stayed constant across space and time. This will assist in the development of an understanding of the type of organisation involved in the iron production and how this changed over time (Costin 2005, pp. 1066-1067; Humphris et al. 2009, Martinón-Torres et al. 2014). Furthermore, since this paper was written, new charcoal samples have been obtained from MIS 3, 4 and 6, as well as other slag mounds at Meroe. Thus the chronological sequence can continue to be developed as research progresses.

In his review essay of 2004, "What do we know about African iron working," Killick (2004a, p. 110) outlines the pitfalls and shortcomings of the attempts to construct successful chronologies for early iron production locations, not least the problematic first-millennium $\mathrm{BC}$ portion of the radiocarbon calibration curve. He notes that the most valuable future research should focus on the reconstruction of the economics of past African metallurgy: "we need to reconstruct how much iron was produced, by what technical processes, over what period of time, how production was organized, where the product went, and how it was consumed." Certainly, this project is working towards these research aims, and the chronology presented in this paper provides a framework within which to fit our ongoing data generation.

In relation to the origins of iron in Africa, considering that most of the reliable dates for iron production in Great Lakes Africa and in West Africa also lie somewhere in the mid-first millennium BC, between 800 and 400 calBC (Killick 2009, p. 2016; although see Holl
2009), we are no closer to understanding whether or not Meroe played a role. However, it should be noted that future excavations will focus in part on reaching the bottom of the metallurgical deposits in MIS4 - thus reaching the presumably earliest iron production waste so far evident at the site. Successful social interpretations (Killick 2004b) of the iron production industries will depend on the availability of well stratified, well documented settlement and archaeological studies, as well as an understanding of ancient demographic data in the region, in addition to interpretations of the technological remains represented within the slag mounds of the Meroe area. Certainly, many questions can be posed in relation to the iron production of the Meroe area and many will remain unanswered. However, the chronology provided here will allow for the ongoing archaeometallurgical analysis and interpretations to be grounded within a chronological framework which will enable at least some of these questions to be answered in time.

Acknowledgements We would like to sincerely thank the National Corporation for Antiquities and Museums in Sudan (NCAM) for permitting the archaeometallurgical research to be carried out and for granting export licences for the samples exported from Sudan for analysis. We would also like to thank UCL Qatar, The Qatar Sudan Archaeology Project (QSAP) and the British Institute in Eastern Africa (BIEA) for providing the funding which has allowed the research and specialist analysis described in this paper to proceed. Archaeobotanical analysis was carried out by Dr. Barbara Eichhorn (Institut für Archäologische Wissenschaften, Archäologie und Archäobotanik Afrikas, GoetheUniversität Frankfurt). The luminescence-dating strategy was designed and implemented by Dana Drake Rosenstein, University of Arizona.

We thank the University of Khartoum for allowing the UCL Qatar team to excavate within the Royal City of Meroe and Dr. Pawel Wolf for the collaboration which enabled the excavations at Hamadab. Too many people have worked on the excavations and in the laboratories and offices during the post excavation work to name individually, but these people have all contributed greatly to the success of the project and we owe them huge thanks. In particular, we thank the NCAM inspectors for their invaluable guidance and support in the field. We would also like to thank David Killick, Pawel Wolf, Katie Manning and Thilo Rehren for their constructive comments on early drafts of this paper.

Funding Parts of this study were funded by grants from QSAP (Qatar Sudan Archaeology Project), grant 037, and the British Institute in Eastern Africa.

\section{Compliance with Ethical Standards}

Conflict of Interest The authors declare that they have no conflict of interest. 


\section{Appendix}

\begin{tabular}{|c|c|c|c|c|c|c|c|c|c|c|c|}
\hline \multirow{3}{*}{\begin{tabular}{|c|} 
A 01 \\
Fieldwork Sample Details \\
$\begin{array}{c}\text { Trench/Section/Context } \\
\text { in stratigraphic top-down sequence } \\
\text { per trench }\end{array}$ \\
\end{tabular}} & \multicolumn{10}{|c|}{${ }^{14} \mathrm{C}$ Dates Meroe: MIS4 } & \\
\hline & \multicolumn{5}{|c|}{ Laboratory Data } & \multicolumn{6}{|c|}{$\begin{array}{l}\text { Calibration calBC } \\
\text { OxCalv. 4.2.4 (Bronk Ramsey 2009a), curve intCal13 (Reimer et al. } 2013\end{array}$} \\
\hline & AA\# & $\begin{array}{l}\delta 13 C \\
\text { value }\end{array}$ & $F(\delta 13 C)$ & $\begin{array}{c}\delta \mathrm{F} \\
(\delta 13 \mathrm{C})\end{array}$ & $\begin{array}{c}{ }^{14} \mathrm{CAge} \\
\text { BP } \\
\pm 1 \sigma \\
\end{array}$ & $\begin{array}{r}95.4 \% \\
\text { ranges }\end{array}$ & from & to & $\mu$ & $\sigma$ & m \\
\hline MIS4-1-13/W/4003 & AA102868 & -26.0 & 0.7492 & 0.0039 & $\begin{array}{l}2,320 \\
\pm 41\end{array}$ & $\begin{array}{r}80,1 \\
14,5 \\
0,8 \\
\end{array}$ & $\begin{array}{l}-515 \\
-297 \\
-221 \\
\end{array}$ & $\begin{array}{l}-352 \\
-228 \\
-211 \\
\end{array}$ & -381 & \pm 70 & -390 \\
\hline MIS4-1-13/N/4012 & AA102867 & -25.2 & 0.7529 & 0.0038 & $\begin{array}{c}2,280 \\
\pm 41\end{array}$ & $\begin{array}{l}47,4 \\
48,0\end{array}$ & $\begin{array}{l}-406 \\
-321\end{array}$ & $\begin{array}{l}-346 \\
-206\end{array}$ & -320 & \pm 63 & -333 \\
\hline MIS4-1-13/N/4017 - Outlier & AA102866 & -24.8 & 0.7382 & 0.0038 & $\begin{array}{c}2,438 \\
\pm 41\end{array}$ & $\begin{array}{l}22,4 \\
13,8 \\
59,2\end{array}$ & $\begin{array}{l}-755 \\
-671 \\
-596\end{array}$ & $\begin{array}{l}-680 \\
-607 \\
-406\end{array}$ & -572 & \pm 107 & -547 \\
\hline MIS4-1-13/N/4021 & AA102865 & -25.4 & 0.7546 & 0.0038 & $\begin{array}{c}2,262 \\
\pm 41\end{array}$ & $\begin{aligned} 36,4 \\
59,0\end{aligned}$ & $\begin{array}{l}-401 \\
-324\end{array}$ & $\begin{array}{l}-344 \\
-205\end{array}$ & -304 & \pm 60 & -291 \\
\hline MIS4-2-13/W/4029 & AA102872 & -25.5 & 0.7485 & 0.0031 & $\begin{array}{c}2,327 \\
\pm 33\end{array}$ & \begin{tabular}{r|r|}
0.5 \\
91.8 \\
3.1
\end{tabular} & \begin{tabular}{l|}
-507 \\
-490 \\
-281
\end{tabular} & $\begin{array}{l}-501 \\
-357 \\
-257\end{array}$ & -394 & \pm 45 & -395 \\
\hline MIS4-2-13/N/4045 & AA102871 & -25.8 & 0.7514 & 0.0044 & $\begin{array}{c}2,296 \\
\pm 47\end{array}$ & \begin{tabular}{r|r|}
0.7 \\
0.6 \\
94.1 \\
\end{tabular} & $\begin{array}{l}-473 \\
-455 \\
-431 \\
\end{array}$ & $\begin{array}{l}-461 \\
-445 \\
-203 \\
\end{array}$ & -337 & \pm 73 & -365 \\
\hline MIS4-2-13/N/4052 - Outlier & AA102870 & -26.9 & 0.7244 & 0.0038 & $\begin{array}{c}2,590 \\
\pm 42\end{array}$ & $\begin{array}{r}73.9 \\
5.2 \\
16.2 \\
\end{array}$ & $\begin{array}{l}-833 \\
-686 \\
-644 \\
\end{array}$ & $\begin{array}{l}-744 \\
-665 \\
-551 \\
\end{array}$ & .749 & \pm 77 & -783 \\
\hline MIS4-2-13/N/4054 & AA102869 & -25.9 & 0.7518 & 0.0037 & $\begin{array}{c}2,292 \\
\pm 39\end{array}$ & $\begin{array}{l}58.7 \\
36.7\end{array}$ & $\begin{array}{l}-409 \\
-309\end{array}$ & $\begin{array}{l}-350 \\
-209\end{array}$ & -336 & \pm 63 & -367 \\
\hline MIS4-3-13/W/4060 & AA102875 & -25.1 & 0.7526 & 0.0035 & $\begin{array}{c}2,283 \\
\pm 37\end{array}$ & \begin{tabular}{r|r}
53.8 \\
41.6
\end{tabular} & $\begin{array}{l}-405 \\
-307\end{array}$ & $\begin{array}{l}-350 \\
-209\end{array}$ & -327 & \pm 62 & -361 \\
\hline MIS4-3-13/N/4069 & AA102874 & -23.1 & 0.7397 & 0.0032 & $\begin{array}{c}2,422 \\
\pm 35\end{array}$ & \begin{tabular}{r|r}
17.8 \\
6.2 \\
0.4 \\
71.0
\end{tabular} & $\begin{array}{l}-751 \\
-669 \\
-622 \\
-591\end{array}$ & $\begin{array}{l}-683 \\
-638 \\
-617 \\
-402\end{array}$ & -540 & \pm 104 & -508 \\
\hline MIS4-3-13/N/4075 (humates) & AA102873 & -25.5 & 0.7396 & 0.0037 & $\begin{array}{c}2,424 \\
\pm 40\end{array}$ & $\begin{array}{r}19.1 \\
9.5 \\
66.8\end{array}$ & $\begin{array}{l}-752 \\
-669 \\
-593\end{array}$ & $\begin{array}{l}-682 \\
-613 \\
-402\end{array}$ & -551 & \pm 107 & -519 \\
\hline MIS4-3-13/N/4075 (charcoal) & AA102873 & -26.0 & 0.7350 & 0.0042 & $\begin{array}{c}2,473 \\
\pm 46\end{array}$ & $\begin{array}{r}94.8 \\
0.6\end{array}$ & $\begin{array}{l}-771 \\
-420 \\
\end{array}$ & $\begin{array}{l}-428 \\
-416 \\
\end{array}$ & -612 & \pm 99 & -617 \\
\hline MIS4-4-13/W/4077 - Outlier & AA102876 & -25.9 & 0.7560 & 0.0037 & $\begin{array}{c}2,247 \\
\pm 39\end{array}$ & \begin{tabular}{l|l|}
29.4 \\
66.0
\end{tabular} & $\begin{array}{l}-396 \\
-328 \\
\end{array}$ & $\begin{array}{l}-340 \\
-204\end{array}$ & -295 & \pm 57 & -284 \\
\hline MIS4-4-13/W/4082 & AA102877 & -26.1 & 0.7627 & 0.0037 & $\begin{array}{c}2,176 \\
\pm 39\end{array}$ & $\begin{array}{r}91.2 \\
4.2\end{array}$ & $\begin{array}{l}-366 \\
-142\end{array}$ & $\begin{array}{l}-148 \\
-112\end{array}$ & -256 & \pm 72 & -259 \\
\hline MIS4-4-13/W/4085 & AA102878 & -26.2 & 0.7413 & 0.0037 & $\begin{array}{c}2,404 \\
\pm 40\end{array}$ & $\begin{array}{r}14.3 \\
4.8 \\
76.3 \\
\end{array}$ & $\begin{array}{l}-750 \\
-668 \\
-590 \\
\end{array}$ & $\begin{array}{r}-683 \\
-639 \\
-396 \\
\end{array}$ & -523 & \pm 101 & -491 \\
\hline MIS4-5-13/W/4097 - Outlier & AA102880 & -25.1 & 0.7549 & 0.0037 & $\begin{array}{c}2,258 \\
\pm 40\end{array}$ & \begin{tabular}{l|l|l|}
34.5 & \\
60.9 & \\
\end{tabular} & $\begin{array}{l}-399 \\
-323 \\
\end{array}$ & $\begin{array}{l}-344 \\
-205 \\
\end{array}$ & -302 & \pm 59 & -288 \\
\hline MIS4-5-13/W/4098 & AA102879 & -24.8 & 0.7586 & 0.0037 & $\begin{array}{c}2,220 \\
\pm 39\end{array}$ & 95.4 & -387 & -197 & -283 & \pm 55 & -281 \\
\hline MIS4-5-13/W/4100 & AA102881 & -24.8 & 0.7639 & 0.0037 & $\begin{array}{c}2,163 \\
\pm 39\end{array}$ & 95.4 & -361 & -96 & -238 & \pm 80 & -227 \\
\hline
\end{tabular}




\section{A 02}

${ }^{14} \mathrm{C}$ Dates Meroe: MIS2

\begin{tabular}{|c|c|c|c|c|c|c|c|c|c|c|c|}
\hline Fieldwork Sample Details & \multicolumn{5}{|c|}{ Laboratory Data } & \multicolumn{6}{|c|}{\begin{tabular}{|c} 
Calibration calBC \\
OxCalv. 4.2.4 (Bronk Ramsey 2009a), Curve intCal13 (Reimer et al. 2013
\end{tabular}} \\
\hline $\begin{array}{l}\text { Trench/Section/Context } \\
\text { in stratigraphic top-down sequence } \\
\text { per trench }\end{array}$ & AA\# & $\begin{array}{l}\delta 13 C \\
\text { value }\end{array}$ & $F(\delta 13 C)$ & $\begin{array}{c}\delta F \\
(\delta 13 C)\end{array}$ & $\begin{array}{l}{ }^{14} \mathrm{C} \text { Age } \\
\text { BP } \\
\pm 1 \sigma\end{array}$ & $\begin{array}{r}95.4 \% \\
\text { ranges }\end{array}$ & from & to & $\mu$ & $\sigma$ & m \\
\hline MIS2-1-13/W/2005 - Outlier & AA102862 & -24.0 & 0.7508 & 0.0038 & $\begin{array}{c}2,302 \\
\pm 40\end{array}$ & $\begin{array}{l}64.8 \\
30.6\end{array}$ & $\begin{array}{l}-430 \\
-320\end{array}$ & $\begin{array}{l}-347 \\
-207\end{array}$ & -349 & \pm 65 & -375 \\
\hline MIS2-1-13/W/2010 & AA102863 & -27.2 & 0.7588 & 0.0038 & $\begin{array}{c}2,218 \\
\pm 41\end{array}$ & 95.4 & -388 & -193 & -282 & \pm 57 & -281 \\
\hline MIS2-1-13/W/2013 & AA102864 & -26.7 & 0.7510 & 0.0038 & $\begin{array}{c}2,301 \\
\pm 41\end{array}$ & $\begin{array}{r}0.3 \\
62.7 \\
32.4\end{array}$ & $\begin{array}{l}-453 \\
-430 \\
-321\end{array}$ & $\begin{array}{l}-446 \\
-346 \\
-206\end{array}$ & -346 & \pm 66 & -374 \\
\hline
\end{tabular}

\begin{tabular}{|c|c|c|c|c|c|c|c|c|c|c|c|}
\hline \multirow{3}{*}{$\begin{array}{c}\text { A 03a } \\
\text { Fieldwork Sample Details } \\
\begin{array}{c}\text { Trench/Section/Context } \\
\text { in stratigraphic top-down sequence } \\
\text { per trench }\end{array} \\
\end{array}$} & \multicolumn{11}{|c|}{${ }^{14} \mathrm{C}$ Dates Meroe: MIS3 - Trenches 1-13 and 2-14 } \\
\hline & \multicolumn{5}{|c|}{ Laboratory Data } & \multicolumn{6}{|c|}{$\begin{array}{c}\text { Calibration calBC } \\
\text { OxCal v. 4.2.4 (Bronk Ramsey 2009a), Curve IntCol13 (Reimer et al. } 2013\end{array}$} \\
\hline & AA\# & $\begin{array}{l}\delta 13 C \\
\text { value }\end{array}$ & $F(\delta 13 C)$ & $\begin{array}{c}\delta F \\
(\delta 13 C)\end{array}$ & $\begin{array}{c}{ }^{14} \mathrm{C} \text { Age } \\
\text { BP } \\
\pm 1 \sigma \\
\end{array}$ & $\begin{array}{r}95.4 \% \\
\text { ranges }\end{array}$ & from & to & $\mu$ & $\sigma$ & m \\
\hline MIS3-1-13/E/3010 - Outlier & AA102886 & -26.2 & 0.7591 & 0.0037 & $\begin{array}{c}2,214 \\
\pm 39\end{array}$ & 95.4 & -385 & -186 & -281 & \pm 56 & -281 \\
\hline MIS3-1-13/E/3012 & AA102887 & -26.4 & 0.7618 & 0.0037 & $\begin{array}{c}2,186 \\
\pm 39\end{array}$ & $\begin{array}{r}94.1 \\
1.3 \\
\end{array}$ & $\begin{array}{l}-377 \\
-131 \\
\end{array}$ & $\begin{array}{l}-161 \\
-119 \\
\end{array}$ & -266 & \pm 66 & -274 \\
\hline MIS3-1-13/E/3015 & AA102888 & -26.5 & 0.7612 & 0.0037 & $\begin{array}{c}2,192 \\
\pm 39\end{array}$ & $\begin{array}{r}95.0 \\
0.4 \\
\end{array}$ & $\begin{array}{l}-381 \\
-127 \\
\end{array}$ & $\begin{array}{l}-164 \\
-123 \\
\end{array}$ & -270 & \pm 63 & -277 \\
\hline MIS3-2-14/E/3095 & AA106765 & -24.2 & 0.7575 & 0.0027 & $\begin{array}{c}2,231 \\
\pm 28\end{array}$ & $\begin{array}{l}20.5 \\
74.9 \\
\end{array}$ & $\begin{array}{l}-385 \\
-327\end{array}$ & $\begin{array}{l}-341 \\
-204\end{array}$ & -285 & \pm 51 & -277 \\
\hline MIS3-2-14/E/3095 & AA106766 & -24.6 & 0.7558 & 0.0022 & $\begin{array}{c}2,249 \\
\pm 24\end{array}$ & $\begin{array}{ll}31.6 \\
63.8\end{array}$ & $\begin{array}{l}-391 \\
-311\end{array}$ & $\begin{array}{l}-350 \\
-209\end{array}$ & -297 & \pm 56 & -279 \\
\hline MIS3-2-14/E/3093 & AA106761 & -25.8 & 0.7575 & 0.0036 & $\begin{array}{c}2,231 \\
\pm 38\end{array}$ & 95.4 & -386 & -203 & -287 & \pm 55 & -281 \\
\hline MIS3-2-14/E/3093 - Outlier & AA106760 & -24.1 & 0.752 & 0.0025 & $\begin{array}{c}2,289 \\
\pm 27\end{array}$ & $\begin{array}{l}74.9 \\
20.5 \\
\end{array}$ & $\begin{array}{l}-404 \\
-287 \\
\end{array}$ & $\begin{array}{l}-356 \\
-234 \\
\end{array}$ & -352 & \pm 53 & -377 \\
\hline MIS3-2-14/E/3086 & AA106759 & -25.7 & $0.7577+$ & $0.0048+$ & $\begin{array}{c}2,229 \\
\pm 51+\end{array}$ & 95.4 & -396 & -183 & -284 & \pm 63 & -283 \\
\hline MIS3-2-14/E/3071 & AA106763 & -26.3 & 0.7583 & 0.0028 & $\begin{array}{c}2,222 \\
\pm 30\end{array}$ & 95.4 & -377 & -204 & -283 & \pm 51 & 279 \\
\hline MIS3-2-14/E/3071 & AA106764 & -25.1 & $0.7589+$ & $0.0047+$ & $\begin{array}{l}2207 \\
\pm 50+\end{array}$ & $\begin{array}{r}94.7 \\
0.7\end{array}$ & $\begin{array}{l}-394 \\
-129\end{array}$ & $\begin{array}{l}-163 \\
-120\end{array}$ & -273 & \pm 67 & -277 \\
\hline MIS3-2-14/E/3070 & AA106762 & -25.4 & 0.7507 & 0.0022 & $\begin{array}{l}2,304 \\
\pm 23+\end{array}$ & $\begin{array}{r}93.1 \\
2.3\end{array}$ & $\begin{array}{l}-406 \\
-272\end{array}$ & $\begin{array}{l}-359 \\
-261\end{array}$ & -379 & \pm 31 & -388 \\
\hline
\end{tabular}




\begin{tabular}{|c|c|c|c|c|c|c|c|c|c|c|c|}
\hline \multirow{3}{*}{\begin{tabular}{|c|} 
A 03b \\
Fieldwork Sample Details \\
$\begin{array}{c}\text { Trench/Section/Context } \\
\text { in stratigraphic top-down sequence } \\
\text { per trench }\end{array}$ \\
\end{tabular}} & \multicolumn{11}{|c|}{${ }^{14} \mathrm{C}$ Dates Meroe: MIS3 - Trench 3-14 } \\
\hline & \multicolumn{5}{|c|}{ Laboratory Data } & \multicolumn{6}{|c|}{ 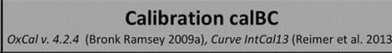 } \\
\hline & AA\# & $\begin{array}{l}\delta 13 C \\
\text { value }\end{array}$ & $F(\delta 13 c)$ & $\begin{array}{c}\delta \mathrm{F} \\
(\delta 13 \mathrm{C})\end{array}$ & $\begin{array}{c}{ }^{14} \mathrm{CAg} \\
\mathrm{BP} \\
\pm 10\end{array}$ & $\begin{array}{c}95.4 \% \\
\text { ranges }\end{array}$ & from & to & $\mu$ & $\sigma$ & $\mathrm{m}$ \\
\hline Mis 3-3-14/E/3138 & AA106757 & -24.2 & 0.7525 & 0.0026 & $\begin{array}{c}2,284 \\
\pm 27\end{array}$ & $\begin{array}{l}69.6 \\
25.8\end{array}$ & $\begin{array}{l}-403 \\
-291\end{array}$ & $\begin{array}{l}-354 \\
-231\end{array}$ & -345 & \pm 56 & -373 \\
\hline Mis 3-3-14//E/3138 & AA106758 & \begin{tabular}{|c|c|}
-24.8 \\
-1
\end{tabular}$y$ & \begin{tabular}{|l|l|}
0.7543 \\
\end{tabular} & 0.0023 & $\begin{array}{c}2,266 \\
\pm 25\end{array}$ & $\begin{array}{r}50.9 \\
42.2 \\
2.2 \\
\end{array}$ & $\begin{array}{l}-399 \\
-297 \\
-221 \\
\end{array}$ & $\begin{array}{l}-352 \\
-228 \\
-211 \\
\end{array}$ & -320 & \pm 59 & -355 \\
\hline MIS 3-3-14/E/3130 & AA106756 & -25.5 & 0.7524 & 0.0026 & $\begin{array}{c}2,285 \\
\pm 28\end{array}$ & $\begin{array}{r}69.2 \\
26.2\end{array}$ & $\begin{array}{l}-404 \\
-292\end{array}$ & $\begin{array}{l}-353 \\
-231\end{array}$ & -344 & \pm 56 & -373 \\
\hline Mis 3-3-14/E/3067 & AA106754 & -26.2 & \begin{tabular}{|l|l|}
$0.7532+$ \\
\end{tabular} & $0.0040+$ & $\begin{array}{c}2,277+ \\
\pm 43+\end{array}$ & 95.4 & -396 & -203 & -294 & \pm 58 & -285 \\
\hline MIS 3-3-14/E//3067 - Outlier & AA106755 & -25.9 & \begin{tabular}{|l|l|}
0.7527 \\
\end{tabular} & 0.0026 & $\begin{array}{c}2,282 \\
\pm 28\end{array}$ & \begin{tabular}{r|}
86.9 \\
7.3 \\
1.3 \\
\end{tabular} & $\begin{array}{l}-409 \\
-283 \\
-245\end{array}$ & $\begin{array}{l}-357 \\
-255 \\
.236\end{array}$ & -371 & \pm 42 & -376 \\
\hline MIS 3-3-14/E//3122 - Outilier & AA106753 & -25.8 & 0.76 & 0.0031 & $\begin{array}{c}2,204 \\
\pm 33\end{array}$ & 95.4 & -375 & -186 & -279 & \pm 54 & -283 \\
\hline MIS 3-3-14/E/3065 & AA106748 & -26.5 & 0.7583 & 0.0026 & $\begin{array}{c}2,222 \\
\pm 28\end{array}$ & $\begin{array}{l}17.9 \\
77.5\end{array}$ & $\begin{array}{l}-377 \\
-330\end{array}$ & $\begin{array}{l}-336 \\
-204\end{array}$ & -282 & \pm 50 & -278 \\
\hline MIS 3-3-14/E/3065 & AA106749 & -25.5 & \begin{tabular}{|l|l|}
0.7557 \\
\end{tabular} & 0.0026 & $\begin{array}{c}2,250 \\
\pm 28\end{array}$ & $\begin{array}{l}31.6 \\
63.8\end{array}$ & $\begin{array}{l}-393 \\
-316\end{array}$ & $\begin{array}{l}-348 \\
-208\end{array}$ & -298 & \pm 56 & -281 \\
\hline MIS 3-3-14/E/3107 & AA106751 & -25.6 & \begin{tabular}{|l|}
0.7561 \\
\end{tabular} & 0.0027 & $\begin{array}{c}2,246 \\
\pm 29\end{array}$ & $\begin{array}{l}28.6 \\
66.8\end{array}$ & $\begin{array}{l}-393 \\
-321\end{array}$ & $\begin{array}{l}-346 \\
-206\end{array}$ & -294 & \pm 55 & -280 \\
\hline MIS 3-3-14/E/3107 & AA106752 & -25.3 & $0.7506+$ & $0.0037+$ & $\begin{array}{c}2305+ \\
\pm 40+\end{array}$ & $\begin{array}{c}0.4 \\
66.8 \\
27.9\end{array}$ & $\begin{array}{l}-453 \\
-430 \\
-316\end{array}$ & $\begin{array}{l}-446 \\
-348 \\
-208\end{array}$ & -353 & \pm 65 & -378 \\
\hline MIS 3-3-14/E/3097 & AA106750 & -25.3 & \begin{tabular}{|l|l|}
0.7516 \\
\end{tabular} & 0.0026 & $\begin{array}{c}2,294 \\
\pm 28\end{array}$ & $\begin{array}{l}77.8 \\
17.6\end{array}$ & \begin{tabular}{|l}
-405 \\
-287
\end{tabular} & $\begin{array}{l}-356 \\
-234\end{array}$ & -357 & \pm 51 & -380 \\
\hline MIS 3-3-14/E/3096 & AA106743 & -26.1 & \begin{tabular}{|l}
0.7551 \\
\end{tabular} & 0.0026 & $\begin{array}{c}2,257 \\
\pm 28\end{array}$ & $\begin{array}{r}37.8 \\
57.6\end{array}$ & $\begin{array}{l}-396 \\
-311\end{array}$ & $\begin{array}{l}-350 \\
-209\end{array}$ & -305 & \pm 58 & -286 \\
\hline MIS 3-3-14////3058 - Outlier & AA106746 & -25.8 & 0.759 & 0.0027 & $\begin{array}{r}2,216 \\
\pm 28 \\
\end{array}$ & 95.4 & -371 & -202 & -281 & \pm 50 & -279 \\
\hline MIS 3-3-14/E/3058 & AA106747 & -27.2 & 0.7575 & 0.0028 & $\begin{array}{c}2,231 \\
\pm 29\end{array}$ & $\begin{array}{l}20.7 \\
74.7\end{array}$ & $\begin{array}{l}-385 \\
-327\end{array}$ & $\begin{array}{r}-341 \\
-204\end{array}$ & -285 & \pm 51 & -278 \\
\hline MIS 3-3-14////3054 & AA106742 & -24.2 & 0.7577 & 0.0024 & $\begin{array}{r}2,229 \\
\pm 25 \\
\end{array}$ & $\begin{array}{l}18.6 \\
76.8 \\
\end{array}$ & \begin{tabular}{|l}
-382 \\
-325 \\
\end{tabular} & $\begin{array}{r}-343 \\
-204 \\
\end{array}$ & -283 & \pm 50 & -275 \\
\hline MIS 3-3-3-14/E/3044 & AA106745 & -26.9 & \begin{tabular}{|l|l|} 
& 0.7558 \\
\end{tabular} & 0.0026 & $\begin{array}{c}2,249 \\
\pm 28\end{array}$ & 95.4 & -405 & -177 & -294 & \pm 69 & -288 \\
\hline MIS 3-3-14/E/3044 & AA106744 & -24.1 & 0.7534 & 0.0054 & $\begin{array}{c}2,275 \\
\pm 58\end{array}$ & $\begin{array}{l}62.8 \\
32.6\end{array}$ & $\begin{array}{l}-400 \\
-292\end{array}$ & $\begin{array}{l}-353 \\
-231\end{array}$ & -334 & \pm 58 & -367 \\
\hline
\end{tabular}

\begin{tabular}{|c|c|c|c|c|c|c|c|c|c|c|c|}
\hline \multicolumn{12}{|c|}{${ }^{14} \mathrm{C}$ Dates Meroe: MIS1/2 } \\
\hline Fieldwork Sample Details & \multicolumn{5}{|c|}{ Laboratory Data } & \multicolumn{6}{|c|}{$\begin{array}{l}\text { Calibration calBC } \\
\text { Oxcalv v.42.24 (Bronk Ramsey 2009a), Curve IntCal13 (RReimer et a. 2013) }\end{array}$} \\
\hline $\begin{array}{c}\text { Trench/Section/Context } \\
\text { in stratigraphic top-down sequence } \\
\text { per trench }\end{array}$ & AA\#\# & $\begin{array}{l}\delta 13 c \\
\text { value }\end{array}$ & $F(\delta 13 C)$ & $\begin{array}{c}\delta \mathrm{F} \\
(\delta 13 \mathrm{C})\end{array}$ & $\begin{array}{c}{ }_{14}^{14} \mathrm{CAge} \\
\text { BP } \\
\pm 10\end{array}$ & $\begin{array}{l}95.4 \% \\
\text { ranges }\end{array}$ & from & to & $\underline{\mu}$ & $\sigma$ & m \\
\hline MIS1/2-2-13/N/2022 upper part & AA102883 & -23.8 & 0.7714 & 0.0038 & $\begin{array}{c}2,085 \\
\pm 39\end{array}$ & 95.4 & -201 & 2 & -110 & \pm 58 & -108 \\
\hline MIS1/2-2-13/N/2022 lower part & AA102882 & -25.0 & 0.7597 & 0.0037 & $\begin{array}{c}2,208 \\
\pm 39\end{array}$ & 95.4 & -381 & -181 & -279 & \pm 57 & -281 \\
\hline MIS1/2-3-13/N/2020 upper part & AA 102884 & -25.1 & 0.7590 & 0.0037 & $\begin{array}{c}2,215 \\
\pm 39\end{array}$ & 95.4 & -386 & -192 & .281 & \pm 56 & -281 \\
\hline MIS1/2-3-13/N/2020 lower part & AA 102885 & -24.9 & 0.7614 & 0.0037 & $\begin{array}{c}2,190 \\
\pm 39\end{array}$ & $\begin{array}{r}95.2 \\
0.2\end{array}$ & $\begin{array}{l}-379 \\
-127\end{array}$ & $\begin{array}{l}-164 \\
-124\end{array}$ & -269 & \pm 64 & -277 \\
\hline
\end{tabular}

\begin{tabular}{|c|c|c|c|c|c|c|c|c|c|c|c|}
\hline \multirow{3}{*}{\begin{tabular}{|c|} 
A 05 \\
Fieldwork Sample Details \\
$\begin{array}{c}\text { Trench/Context and Interpretation } \\
\text { in functional phases and stratigraphic } \\
\text { top-down sequence }\end{array}$ \\
\end{tabular}} & \multicolumn{11}{|c|}{${ }^{14} \mathrm{C}$ Dates Meroe: MIS6 Furnace Workshop } \\
\hline & \multicolumn{5}{|c|}{ Laboratory Data } & \multicolumn{6}{|c|}{$\begin{array}{l}\text { Calibration calAD } \\
\text { Oxcalv. 4.2.4 (Bronk Ramsey 2009a), Curve IntCCol13 (Reimer et al. 2013) }\end{array}$} \\
\hline & AA\# & $\begin{array}{l}\delta 13 \mathrm{C} \\
\text { value }\end{array}$ & $F(\delta 13 C)$ & $\begin{array}{c}\delta \mathrm{F} \\
(\delta 13 \mathrm{C}) \\
\end{array}$ & $\begin{array}{c}{ }^{14} \mathrm{C} \mathrm{CAge} \\
\mathrm{BP} \\
\pm 10 \\
10\end{array}$ & $\begin{array}{r}95.4 \% \\
\text { ranges }\end{array}$ & from & to & $\mu$ & $\sigma$ & $\mathrm{m}$ \\
\hline \begin{tabular}{|l} 
MIS6-1-14/FW210: post-use deposit \\
- Outlier
\end{tabular} & AA106734 & -25.8 & 0.8021 & 0.0028 & $\begin{array}{c}1,772 \\
\pm 28\end{array}$ & \begin{tabular}{r|r}
9.1 \\
86.3
\end{tabular} & $\begin{array}{l}141 \\
209\end{array}$ & $\begin{array}{l}197 \\
340\end{array}$ & 268 & \pm 49 & 274 \\
\hline $\begin{array}{l}\text { MisS-1-1-14/FW233 = final phase: last dump of } \\
\text { smithing and smetting debris }\end{array}$ & 106737 & -25.3 & 0.8124 & 0.0028 & $\begin{array}{c}1,669 \\
\pm 28\end{array}$ & $\begin{array}{r}3.1 \\
92.3\end{array}$ & $\begin{array}{l}350 \\
379 \\
\end{array}$ & $\begin{array}{l}368 \\
540\end{array}$ & 451 & \pm 53 & 446 \\
\hline $\begin{array}{l}\text { Miss-1-14/FW013 = final phase: remains of } \\
\text { latest smithing activity }\end{array}$ & AA105311 & -23.6 & 0.8151 & 0.0032 & $\begin{array}{c}1,642 \\
\pm 32\end{array}$ & $\begin{array}{ll}79.8 \\
15.6\end{array}$ & $\begin{array}{l}333 \\
485\end{array}$ & $\begin{array}{l}474 \\
535\end{array}$ & 414 & \pm 53 & 406 \\
\hline $\begin{array}{l}\text { Miss-1-1-14/FW219 = final phase: last working } \\
\text { surface in brick-lined pit }\end{array}$ & AA106735 & -26.6 & 0.8174 & 0.0037 & $\begin{array}{c}1,619 \\
\pm 36\end{array}$ & $\begin{array}{r}3.1 \\
92.3\end{array}$ & $\begin{array}{l}350 \\
379\end{array}$ & $\begin{array}{l}368 \\
540\end{array}$ & 451 & \pm 53 & 446 \\
\hline $\begin{array}{l}\text { Mis6-1-14/FW2224 = final phase: remains of } \\
\text { last smelt in furnace }\end{array}$ & AA106736 & -25.9 & 0.8184 & 0.0034 & $\begin{array}{c}1,609 \\
\pm 33\end{array}$ & 95.4 & 388 & 540 & 463 & \pm 48 & 464 \\
\hline $\begin{array}{l}\text { MisG-1-14/FW2224 = final phase: remains of } \\
\text { last smelt in furnace }\end{array}$ & AA106740 & -25.4 & 0.8177 & 0.0025 & $\begin{array}{c}1,616 \\
\pm 24 \\
\end{array}$ & $\begin{array}{r}58.5 \\
36.9 \\
\end{array}$ & $\begin{array}{l}390 \\
485 \\
\end{array}$ & $\begin{array}{l}475 \\
536 \\
\end{array}$ & 456 & \pm 47 & 443 \\
\hline $\begin{array}{l}\text { Mis6-1-14//Fw258: second (not the latest) } \\
\text { phase of workshop floor layer }\end{array}$ & 106738 & -26 & 0.8175 & 0.0026 & $\begin{array}{c}1,619 \\
\pm 25\end{array}$ & $\begin{array}{ll}61.2 \\
34.2 \\
\end{array}$ & $\begin{array}{l}387 \\
484 \\
\end{array}$ & $\begin{array}{l}475 \\
536 \\
\end{array}$ & 452 & \pm 48 & 430 \\
\hline $\begin{array}{l}\text { Mils6-1-14/FW267: first phase of workshop } \\
\text { floor layer }\end{array}$ & AA106739 & -26.7 & 0.818 & 0.0025 & $\begin{array}{l}1,614 \\
\pm 25\end{array}$ & $\begin{array}{l}56.5 \\
38.9 \\
\end{array}$ & $\begin{array}{l}392 \\
484 \\
\end{array}$ & $\begin{array}{l}475 \\
536\end{array}$ & 459 & \pm 47 & 454 \\
\hline $\begin{array}{l}\text { Mis6-1-1-14/FWW262: sorithing he } \\
\text { predating actual workshop }\end{array}$ & AA106741 & -26.6 & 0.816 & 0.0025 & $\begin{array}{l}1,633 \\
\pm 24\end{array}$ & $\begin{array}{r}4.9 \\
70.4 \\
2.4 \\
17.6 \\
\end{array}$ & $\begin{array}{l}345 \\
377 \\
453 \\
487 \\
\end{array}$ & $\begin{array}{l}372 \\
435 \\
470 \\
534 \\
\end{array}$ & 426 & \pm 45 & 413 \\
\hline
\end{tabular}




\begin{tabular}{|c|c|c|c|c|c|c|c|c|c|c|c|}
\hline \multirow{3}{*}{\begin{tabular}{|c|} 
A 06 \\
Fieldwork Sample Details \\
$\begin{array}{c}\text { Trench/Section/Context } \\
\text { in stratigraphic top-down sequence } \\
\text { per trench }\end{array}$ \\
\end{tabular}} & \multicolumn{10}{|c|}{${ }^{14} \mathrm{C}$ Dates Meroe: MIS6 } & \\
\hline & \multicolumn{5}{|c|}{ Laboratory Data } & \multicolumn{6}{|c|}{$\begin{array}{l}\text { Calibration calAD } \\
\text { OxCalv. } 4.2 \text { (Bronk Ramsey 2009a), Curve IntCal13 (Reimer et al. } 2013\end{array}$} \\
\hline & AA\# & $\begin{array}{l}\delta 13 C \\
\text { value }\end{array}$ & $F(\delta 13 C)$ & $\begin{array}{c}\delta F \\
(\delta 13 \mathrm{C})\end{array}$ & $\begin{array}{c}{ }^{14} \mathrm{C} \text { Age } \\
\text { BP } \\
\pm 1 \sigma\end{array}$ & $\begin{array}{r}95.4 \% \\
\text { ranges }\end{array}$ & from & to & $\mu$ & $\sigma$ & m \\
\hline MIS6-1W-14/W/61006T & AA105315 & -25.5 & 0.8152 & 0.0038 & $\begin{array}{c}1,642 \\
\pm 37\end{array}$ & $\begin{array}{l}77.0 \\
18.4\end{array}$ & $\begin{array}{l}332 \\
483\end{array}$ & $\begin{array}{l}477 \\
536\end{array}$ & 416 & \pm 59 & 407 \\
\hline Mis6-1W-14/W/61006Y & AA105316 & -25.3 & 0.815 & 0.0032 & $\begin{array}{c}1,643 \\
\pm 32\end{array}$ & $\begin{array}{l}80.6 \\
14.8\end{array}$ & $\begin{array}{l}332 \\
486\end{array}$ & $\begin{array}{l}474 \\
535\end{array}$ & 413 & 52 & 405 \\
\hline MIS6-1W-14/W/61006B & AA105312 & -26.4 & 0.8063 & 0.0032 & $\begin{array}{c}1,730 \\
\pm 32\end{array}$ & 95.4 & 240 & 390 & 310 & \pm 44 & 309 \\
\hline MIS6-1W-14/W/61006J-K & AA105313 & -25.9 & 0.8108 & 0.0035 & $\begin{array}{c}1,685 \\
\pm 35\end{array}$ & $\begin{array}{l}16.9 \\
78.5\end{array}$ & $\begin{array}{l}255 \\
315\end{array}$ & $\begin{array}{l}302 \\
422\end{array}$ & 352 & \pm 47 & 360 \\
\hline MIS6-1W-14/W/61006Q & AA105314 & -26.4 & 0.8082 & 0.0032 & $\begin{array}{c}1,710 \\
\pm 32\end{array}$ & 95.4 & 250 & 399 & 328 & \pm 45 & 336 \\
\hline MIS6-2-14/E/62009 & AA105317 & -24.3 & 0.8154 & 0.0041 & $\begin{array}{c}1,640 \\
\pm 40\end{array}$ & $\begin{array}{r}0.8 \\
94.6\end{array}$ & $\begin{array}{l}266 \\
332\end{array}$ & $\begin{array}{l}271 \\
538\end{array}$ & 419 & \pm 62 & 410 \\
\hline MIS6-2-14/N/62010 & AA105318 & -27.5 & 0.8111 & 0.0032 & $\begin{array}{c}1,682 \\
\pm 32\end{array}$ & $\begin{array}{l}13.2 \\
82.2\end{array}$ & $\begin{array}{l}256 \\
319\end{array}$ & $\begin{array}{l}298 \\
422\end{array}$ & 357 & \pm 44 & 363 \\
\hline MIS6-2-14/N/62012 & AA105319 & -24.1 & 0.8118 & 0.0032 & $\begin{array}{c}1,675 \\
\pm 32\end{array}$ & $\begin{array}{l}10.0 \\
85.4\end{array}$ & $\begin{array}{l}257 \\
320\end{array}$ & $\begin{array}{l}297 \\
425\end{array}$ & 365 & \pm 44 & 370 \\
\hline MIS6-2-14/N/62013 & AA105320 & -24.2 & 0.8009 & 0.0034 & $\begin{array}{c}1,783 \\
\pm 34\end{array}$ & 95.4 & 134 & 335 & 247 & \pm 58 & 247 \\
\hline MIS6-3-14/S/63003 & AA105309 & -24.4 & 0.8212 & 0.0033 & $\begin{array}{c}1,582 \\
\pm 32\end{array}$ & 95.4 & 405 & 548 & 480 & \pm 41 & 482 \\
\hline MIS6-3-14/E/63001 & AA105308 & -26.1 & 0.818 & 0.0032 & $\begin{array}{c}1,613 \\
\pm 31\end{array}$ & 95.4 & 387 & 539 & 460 & \pm 48 & 459 \\
\hline MIS6-3-14/W/63042 & AA105307 & -26.4 & 0.8183 & 0.0034 & $\begin{array}{c}1,611 \\
\pm 33\end{array}$ & 95.4 & 386 & 541 & 461 & \pm 48 & 462 \\
\hline MIS6-3-14/W/63037 & AA105305 & -26.6 & 0.8099 & 0.0035 & $\begin{array}{c}1,693 \\
\pm 34\end{array}$ & $\begin{array}{l}20.9 \\
74.5\end{array}$ & $\begin{array}{l}254 \\
314\end{array}$ & $\begin{array}{l}303 \\
414\end{array}$ & 344 & \pm 46 & 353 \\
\hline MIS6-3-14/W/63045 & AA105306 & -26.5 & 0.8107 & 0.0027 & $\begin{array}{c}1,686 \\
\pm 27\end{array}$ & $\begin{array}{r}10.2 \\
0.8 \\
84.5\end{array}$ & $\begin{array}{l}258 \\
290 \\
321\end{array}$ & $\begin{array}{l}285 \\
295 \\
417\end{array}$ & 355 & \pm 39 & 362 \\
\hline MIS6-3-14/W/63081 & AA105304 & -25.2 & 0.8023 & 0.0031 & $\begin{array}{c}1,770 \\
\pm 31\end{array}$ & 95.4 & 138 & 345 & 269 & \pm 51 & 276 \\
\hline MIS6-4-14/S/64004 & AA105299 & -24.4 & 0.8135 & 0.0032 & $\begin{array}{c}1,658 \\
\pm 32\end{array}$ & $\begin{array}{r}3.4 \\
86.5 \\
5.6\end{array}$ & $\begin{array}{l}260 \\
325 \\
491\end{array}$ & $\begin{array}{l}280 \\
432 \\
531\end{array}$ & 387 & \pm 47 & 389 \\
\hline MIS6-4-14/S/64035 & AA105300 & -25.9 & 0.8157 & 0.0033 & $\begin{array}{c}1,637 \\
\pm 33\end{array}$ & $\begin{array}{l}75.5 \\
19.9\end{array}$ & $\begin{array}{l}338 \\
485\end{array}$ & $\begin{array}{l}475 \\
535\end{array}$ & 424 & \pm 54 & 412 \\
\hline MIS6-4-14/W/64044 & AA105301 & -25.4 & 0.8124 & 0.0031 & $\begin{array}{c}1,669 \\
\pm 31\end{array}$ & $\begin{array}{r}7.1 \\
88.3\end{array}$ & $\begin{array}{l}257 \\
321\end{array}$ & $\begin{array}{l}296 \\
428\end{array}$ & 372 & \pm 43 & 377 \\
\hline MIS6-4-14/W/64038 & AA105302 & -26.7 & 0.8079 & 0.0031 & $\begin{array}{c}1,714 \\
\pm 31\end{array}$ & 95.4 & 249 & 395 & 324 & \pm 44 & 332 \\
\hline MIS6-4-14/E/64051 & AA105303 & -27.5 & 0.8053 & 0.0031 & $\begin{array}{c}1,740 \\
\pm 31\end{array}$ & 95.4 & 235 & 386 & 301 & \pm 43 & 299 \\
\hline
\end{tabular}




\begin{tabular}{|c|c|c|c|c|c|c|c|c|c|c|c|}
\hline \multirow{3}{*}{\begin{tabular}{|c|} 
A 07 \\
Fieldwork Sample Details \\
$\begin{array}{c}\text { Trench/Section/Context } \\
\text { in stratigraphic top-down sequence } \\
\text { per trench }\end{array}$
\end{tabular}} & \multicolumn{11}{|c|}{${ }^{14} \mathrm{C}$ Dates Hamadab: HMD 100/200/300/800 } \\
\hline & \multicolumn{5}{|c|}{ Laboratory Data } & \multicolumn{6}{|c|}{\begin{tabular}{|c} 
Calibration calAD \\
OxCalv. 4.2.4 (Bronk Ramsey 2009a), Curve IntCol13 (Reimer et al. 2013)
\end{tabular}} \\
\hline & AA\# & $\begin{array}{l}\delta 13 C \\
\text { value }\end{array}$ & $F(\delta 13 C)$ & $\begin{array}{c}\delta F \\
(\delta 13 C)\end{array}$ & $\begin{array}{c}1{ }^{14} \mathrm{C} \mathrm{Age} \\
\mathrm{BP} \\
\pm 10 \\
\end{array}$ & $\begin{array}{r}95.4 \% \\
\text { ranges }\end{array}$ & from & to & $\mu$ & $\sigma$ & $\mathbf{m}$ \\
\hline HMD 100/2012-10/N/12528 - Outlier & AA100356 & -26.2 & 0.8141 & 0.0054 & $\begin{array}{c}1,653 \\
\pm 53\end{array}$ & $\begin{array}{r}9.7 \\
85.7\end{array}$ & $\begin{array}{l}255 \\
316\end{array}$ & $\begin{array}{l}302 \\
539\end{array}$ & 398 & \pm 74 & 395 \\
\hline HMD 100/2012-10/N/12529 & AA100359 & -24.5 & 0.8184 & 0.0051 & $\begin{array}{l}1,609 \\
\pm 50\end{array}$ & 95.4 & 338 & 563 & 457 & \pm 61 & 460 \\
\hline HMD 100/2012-10/W/12530 & AA100358 & -26.8 & 0.8191 & 0.0038 & $\begin{array}{c}1,603 \\
\pm 38\end{array}$ & 95.4 & 383 & 550 & 467 & \pm 49 & 468 \\
\hline HMD 200/2012-08/-/12500 - Outlier & AA100355 & -25.9 & 0.8172 & 0.0039 & $\begin{array}{c}1,621 \\
\pm 38\end{array}$ & 95.4 & 346 & 540 & 448 & \pm 55 & 441 \\
\hline HMD 200/2012-08/N/12501 & AA100353 & -26.1 & 0.8216 & 0.0038 & $\begin{array}{c}1,578 \\
\pm 38\end{array}$ & 95.4 & 401 & 562 & 482 & \pm 44 & 482 \\
\hline HMD 200/2012-08/N/12502 & AA100352 & -25.9 & 0.8145 & 0.0038 & $\begin{array}{c}1,648 \\
\pm 38\end{array}$ & \begin{tabular}{r|}
2.6 \\
78.4 \\
14.5
\end{tabular} & $\begin{array}{l}262 \\
327 \\
485\end{array}$ & $\begin{array}{l}278 \\
475 \\
536\end{array}$ & 405 & \pm 59 & 400 \\
\hline HMD 200/2012-09/N/12519 & AA100351 & -26.1 & 0.8156 & 0.0038 & $\begin{array}{c}1,637 \\
\pm 38\end{array}$ & 95.4 & 335 & 537 & 424 & \pm 59 & 413 \\
\hline HMD 200/2012-09/N/12520 & AA100361 & -25.2 & 0.8266 & 0.0039 & $\begin{array}{c}1,530 \\
\pm 38\end{array}$ & 95.4 & 425 & 605 & 516 & \pm 54 & 523 \\
\hline HMD 200/2012-09/W/12520 - Outlier & AA100348 & -25.7 & 0.8092 & 0.0039 & $\begin{array}{c}1,700 \\
\pm 39 \\
\end{array}$ & 95.4 & 247 & 415 & 336 & \pm 50 & 344 \\
\hline HMD 300/2012-12/W/12542 - Outlier & AA100349 & -24.6 & 0.8035 & 0.0038 & $\begin{array}{c}1,757 \\
\pm 38\end{array}$ & \begin{tabular}{r|}
1.5 \\
4.1 \\
89.8 \\
\end{tabular} & $\begin{array}{l}143 \\
168 \\
210\end{array}$ & $\begin{array}{l}155 \\
195 \\
386 \\
\end{array}$ & 281 & \pm 55 & 286 \\
\hline HMD 300/2012-12/W/12542 & AA100357 & -24.7 & 0.8145 & 0.0038 & $\begin{array}{c}1,648 \\
\pm 37\end{array}$ & \begin{tabular}{r|}
2.4 \\
79.1 \\
13.9
\end{tabular} & $\begin{array}{l}262 \\
327 \\
485\end{array}$ & $\begin{array}{l}278 \\
475 \\
535\end{array}$ & 405 & \pm 58 & 400 \\
\hline HMD 300/2012-12/S/ 12542 & AA100354 & -26.6 & 0.8117 & 0.0038 & $\begin{array}{c}1,676 \\
\pm 38 \\
\end{array}$ & $\begin{array}{r}94.6 \\
0.8 \\
\end{array}$ & $\begin{array}{l}251 \\
497 \\
\end{array}$ & $\begin{array}{l}429 \\
506 \\
\end{array}$ & 362 & \pm 52 & 367 \\
\hline HMD 800/2012-13/W/12557 & AA100360 & -26.7 & 0.821 & 0.0039 & $\begin{array}{c}1,584 \\
\pm 38\end{array}$ & 95.4 & 397 & 558 & 479 & \pm 45 & 480 \\
\hline HMD 800/2012-13/W/12561 & AA100362 & -25.2 & 0.8196 & 0.0038 & $\begin{array}{c}1,598 \\
\pm 37\end{array}$ & 95.4 & 389 & 548 & 471 & \pm 46 & 473 \\
\hline HMD 800/2012-13/S/12560 & AA100350 & -26.7 & 0.8179 & 0.0038 & $\begin{array}{c}1,614 \\
\pm 37\end{array}$ & $\begin{array}{r}1.8 \\
93.6\end{array}$ & $\begin{array}{l}353 \\
380\end{array}$ & $\begin{array}{l}366 \\
543\end{array}$ & 457 & \pm 52 & 457 \\
\hline
\end{tabular}

Open Access This article is distributed under the terms of the Creative Commons Attribution 4.0 International License (http:// creativecommons.org/licenses/by/4.0/), which permits unrestricted use, distribution, and reproduction in any medium, provided you give appropriate credit to the original author(s) and the source, provide a link to the Creative Commons license, and indicate if changes were made.

\section{References}

Abdelrahman, M. F. (2011). A new study concerning Kushite and post-Meroitic iron objects. In V. Rondot, F. Alpi, \& F. Villeneuve (Eds.), La pioche et la plume: Autour du Soudan, du Liban et de la Jordanie. Hommages archéologiques à Patrice Lenoble (pp. 391-402). Paris: PUPS.

Abdu, B., \& Gordon, R. (2004). Iron artifacts from the land of Kush. Journal of Archaeological Science, 31, 979998.

Arkell, A. J. (1961). A history of the Sudan. From the earliest times to 1821. London: The Athlone Press.
Baud, M. (2008). The Meroitic royal city of Muweis: First steps into an urban settlement of riverine upper Nubia. Sudan \& Nubia, 12, 52-63.

Bayliss, A. (2009). Rolling out revolution: Using radiocarbon dating in archaeology. Radiocarbon, 51(1), 123-147.

Bradley, R. J. (1984). Meroitic chronology. In F. Hintze (Ed.), Meroitistische Forschungen 1980, Meroitica 7 (pp. 195211). Berlin: Akademie Verlag.

Bronk Ramsey, C. (2009a). Bayesian analysis of radiocarbon dates. Radiocarbon, 51(1), 337-360.

Bronk Ramsey, C. (2009b). Dealing with outliers and offsets in radiocarbon dating. Radiocarbon, 51(3), 1023-1045.

Clist, B. (2013). Our iron smelting ${ }^{14} \mathrm{C}$ dates from central Africa: From a plain appointment to a full blown relationship. In J. Humphris \& T. Rehren (Eds.), The world of iron (pp. 22-28). London: Archetype.

Comelli, D., Massimo, D., Folco, L., El-Halwagy, M., Frizzi, T., Alberti, R., Capogrosso, V., Elnaggar, A., Hassan, H., Nevin, A., Porcelli, F., Rashed, M. G., \& Valentini, G. (2016). The meteoritic origin of Tutankhamun's iron dagger blade. Meteoritics \& Planetary Science, 51(7), 1301-1309.

Costin, C. L. (2005). Craft production. In H. D. G. Maschner \& C. Chippindale (Eds.), Handbook of archaeological methods, volume II (pp. 1034-1099). New York: Altamira Press. 
Craddock, P. T. (1995). Early metal and mining production. Edinburgh: Edinburgh University Press.

de Maret, d. P. (1985). The smith's myth and the origins of leadership in Central Africa. In R. Haaland \& P. Shinnie (Eds.), African iron working, ancient and traditional (pp. 73-87). Bergen: Norwegian University Press.

Dunham, D. (1963). The west and south cemeteries at Meroe, excavated by the late George Andrew Reisner. Boston: Museum of Fine Arts.

Edwards, D. N. (2004). The Nubian past. An archaeology of the Sudan. London: Routledge.

Eze-Uzomaka, P. (2013). Iron and its influence on the prehistoric site of Lejja. In J. Humphris \& T. Rehren (Eds.), The world of iron (pp. 3-9). London: Archetype.

Garstang, J., Sayce, A. H., \& Griffith, F. L. (1911). Meroe, the city of Ethiopians. Being an account of the first season's excavations on the site, 1909-1910. Oxford: The Clarendon Press.

Grzymski, K. (2005). Meroe, the capital of Kush: Old problems and new discoveries. Sudan \& Nubia, 9, 47-58.

Grzymski, K. (2008). Recent research at the palaces and temples of Meroe: A contribution to the systematic study of the Meroitic civilization. In A. Łajtar \& G. Wlodzimierz (Eds.), Between the cataracts. Proceedings of the 11th International Conference for Nubian Studies, Warsaw University 27 August-2 September 2006 (pp. 227-238). Warsaw: Polish Centre of Mediterranean Archaeology.

Haaland, R., \& Haaland, G. (2007). God of war, worldly ruler, and craft specialists in the Meroitic kingdom of Sudan: Inferring social identity from material remains. Journal of Social Archaeology, 7(3), 373-392.

Hinkel, F. W. (1977). The archaeological map of the Sudan I. A guide to its use and explanation of its principles. Berlin: Akademie Verlag.

Hinkel, F. W. (2000). The pyramids of Meroe. Architecture, construction and reconstruction of a sacred landscape. Sudan \& Nubia, 4, 11-26.

Hinkel, M. (2015). Die hafire im Sudan. Eine untersuchung zur geschichte des frühen wasserspeicherbaus. (completed and edited by W. F. Reineke). The archaeological map of the Sudan, Supplement II. Bonn: Habelt-Verlag.

Holl, A. F. C. (2009). Early west African metallurgies: New data and old orthodoxy. Journal of World Prehistory, 22, 415438.

Humphris, J. (2014). Post-Meroitic iron production: Initial results and interpretations. Sudan \& Nubia, 18, 121-129.

Humphris, J., \& Carey, C. (2016). New methods for investigating slag heaps: Integrating geoprospection, excavation and quantitative methods at Meroe, Sudan. Journal of Archaeological Science, 70, 132-144.

Humphris, J., Martinón-Torres, M., Rehren, T., \& Reid, D. A. M. (2009). Variability in single smelting episodes - A pilot study using iron slag from Uganda. Journal of Archaeological Science, 36(2), 359-369.

Killick, D. (2004a). Review essay. What do we know about Africa iron working? Journal of African Archaeology, 2(1), 97-112.

Killick, D. (2004b). Social constructionist approaches to the study of technology. World Archaeology, 36(4), 571-578.

Killick, D. (2009). Cape to Cairo: The spread of metallurgy through eastern and southern Africa. Journal of World Prehistory, 22(4), 399-414.
Killick, D. (2016). A global perspective on the pyrotechnologies of sub-Saharan Africa. Azania, 51(1), 62-87.

Maisels, C. (2012). The archaeology of politics and power. Where, when and why the first states formed. Oxford: Oxbow Books.

Martinón-Torres, M., Li, X. J., Bevan, A., Xia, Y., Zhao, K., \& Rehren, T. (2014). Forty thousand arms for a single emperor: From chemical data to the labour organisation behind the bronze arrows of the terracotta Army. Journal of Archaeological Method and Theory, 21, 534-562.

McIntosh, S. K. (1999). Pathways to complexity: An Africa perspective. In S. K. McIntosh (Ed.), Beyond chiefdoms: Pathways to complexity in Africa (pp. 1-30). Cambridge: Cambridge University Press.

Ogden, J. (2000). Metals. In P. T. Nicholson \& I. Shaw (Eds.), Ancient Egyptian materials and technology (pp. 148-176). Cambridge: Cambridge University Press.

Pfaffenberger, B. (1992). Social anthropology of technology. Annual Review of Anthropology, 21, 491-516.

Pope, J. (2014). The double kingdom under Taharqo: Studies in the history of Kush and Egypt, c. 690-664 BC. Leiden: Brill.

Rehren, T. (2001). Meroe, iron and Africa. Mitteilungen der Sudanarchäologischen Gesellschaft zu Berlin e. V., 12, 102-109.

Rehren, T., Belgya, T., Jambon, A., Káli, G., Kasztovszky, Z., Kis, Z., Kovács, I., Maróti, B., Martinón-Torres, M., Miniaci, G., Pigott, V., et al. (2013). 5,000 years old Egyptian iron beads made from hammered meteoritic iron. Journal of Archaeological Science, 40, 4785-4792.

Reimer, P. J., Bard, E., Bayliss, A., Beck, J. W., Blackwell, P. G., et al. (2013). IntCal13 and Marine13 radiocarbon age calibration curves 0-50,000 years cal BP. Radiocarbon, 55(4), 1869-1887.

Robertshaw, P. (1999). Seeking and keeping power in BunyoroKitara, Uganda. In S. K. McIntosh (Ed.), Beyond chiefdoms: Pathways to complexity in Africa (pp. 124-135). Cambridge: Cambridge University Press.

Sayce, A. H. (1912). Second interim report on the excavations at Meroë in Ethiopia, part II-the historical results. Liverpool Annals of Archaeology and Anthropology, 4, 55-65.

Scheibner, T. (2004). Neue Erkenntnisse zur Wasserversorgung von Musawwarat es Sufra (I). Das übergeordnete Wasserversorgungssystem-Teil I: Wassergewinnung und speicherung. Mitteilungen der Sudanarchäologischen Gesellschaft zu Berlin e. V., 15, 39-64.

Scheibner, T. (2011). Neue und alte ${ }^{14} \mathrm{C}$-Daten aus Musawwarat es-Sufra und ihre Aussagemöglichkeiten zur absoluten und relativen Chronologie des Fundplatzes. Mitteilungen der Sudanarchäologischen Gesellschaft zu Berlin e. V., 22, 7-40.

Scheibner, T. (2014). Entstehung, Ursprung und Nutzung. Die Hafire in Musawwarat es-Sufra und in der Keraba als Wirtschaftsbauten. In A. Lohwasser \& P. Wolf (Eds.), Ein Forscherleben zwischen den Welten. Zum 80. Geburtstag von Steffen Wenig. Mitteilungen der Sudanarchäologischen Gesellschaft zu Berlin e. V., Sonderheft, 299-322.

Scheibner, T. (2017). Wasserbauliche Infrastruktur und Wassermanagement in Musawwarat es-Sufra in kuschitischer Zeit. Dissertation/Doctoral Thesis. Universität Wien/ University of Vienna. 
Shinnie, P. L. (1967). Meroe. A civilization of the Sudan. New York: Frederick A. Praeger.

Shinnie, P. L. (1985). Iron working at Meroe. In P. L. Shinnie \& R. Haaland (Eds.), African iron working - ancient and traditional (pp. 28-35). Oxford: Oxford University Press.

Shinnie, P. L., \& Anderson, J. R. (2004). The capital of Kush 2. Meroe excavations 1973-1984. Meroitica, 20.

Shinnie, P. L., \& Kense, F. J. (1982). Meroitic iron working. Meroitica, 6, 17-28.

Steier, P., \& Rom, W. (2000). The use of Bayesian statistics for 14C dates of chronologically ordered samples: A critical analysis. Radiocarbon, 42(2), 183-198.

Török, L. (1997a). Meroe City: An ancient African capital. John Garstang's excavations in the Sudan. London: EES.

Török, L. (1997b). The kingdom of Kush. Handbook of the Napatan-Meroitic civilization. Leiden: Brill.

Török, L. (2015). The periods of Kushite history, from the tenth century $B C$ to the $A D$ fourth century. Budapest: Ízisz Foundation.

Trigger, B. G. (1969). The myth of Meroe and the African Iron Age. African Historical Studies, 2(1), 23-50.

Tylecote, R. F. (1970). Iron working at Meroe, Sudan. Bulletin of the Historical Metallurgy Group, 2, 23-50.

Tylecote, R. F. (1982). Metal working at Meroe, Sudan. Meroitica, 6, 29-42.
Van Grunderbeek, M.-C. (1992). Essai de delimitation chronologique de l'age du fer ancient au Burundi, au Rwanda et dans la region des Grands Lacs. Azania, 27, 5380.

Wainwright, G. A. (1945). Iron in the Napatan and Meroitic ages. Sudan Notes and Records, 26(1), 5-36.

Walanus, A. (2009). Systematic bias of radiocarbon method. Radiocarbon, 51(2), 433-436.

Welsby, D. A. (1996). The kingdom of Kush. The Napatan and Meroitic empires. Princeton: Markus Wiener Publishers.

Weninger, F., Steier, P., Kutschera, W., Wild, E. M., et al. (2010). Robust Bayesian analysis, an attempt to improve Bayesian sequencing. Radiocarbon, 52(2-3), 962-983.

Weninger, B., Edinborough, K., Clare, L., Jöris, O., et al. (2011). Concepts of probability in radiocarbon analysis. Documenta Praehistorica, XXXVIII, 1-20.

Wickens, G. E. (1995). The role of the Acacia species in the rural economy of dry Africa and the Near East. Rome: FAO Conservation Guide 27, Fiat Panis.

Žabkar, L. V. (1975). Apedemak, lion god of Meroe. Warminster: Aris \& Phillips LTD. 